\title{
j(men
}

INSTITUTO DE PESQUISAS ENERGÉTICAS E NUCLEARES

Autarquia Associada à Universidade de São Paulo

ESTUDO DO PROCESSO DE DENSIFICAÇÃO DE COMBUSTÍVEIS URÂNIO-ÉRBIO PARA

REATORES DO TIPO ÁGUA LEVE

ARTUR CESAR DE FREITAS

Dissertação apresentada como parte dos requisitos para obtenção do Grau de Mestre em Ciências na Área de Tecnologia Nuclear Materiais

Orientadora:

Profa. Dra. Elita F. Urano de Carvalho 


\title{
INSTITUTO DE PESQUISAS ENERGÉTICAS E NUCLEARES
}

Autarquia associada à Universidade de São Paulo

\section{ESTUDO DO PROCESSO DE DENSIFICAÇÃO DE COMBUSTÍVEIS URÂNIO-ÉRBIO PARA REATORES DO TIPO ÁGUA LEVE}

\author{
ARTUR CESAR DE FREITAS
}

Dissertação apresentada como parte dos requisitos para obtenção do Grau de Mestre em Ciências na Área de Tecnologia Nuclear - Materiais

Orientadora:

Profa. Dra. Elita F. Urano de Carvalho

\section{Versão corrigida}

Versão original disponível no IPEN

São Paulo

2017 


\section{FOLHA DE APROVAÇÃO}

Autor: Artur Cesar de Freitas

Título: Estudo do processo de densificação de combustíveis urânio-érbio para reatores do tipo água leve

Dissertação apresentada ao Programa de Pós-Graduação em Tecnologia Nuclear da Universidade de São Paulo para obtenção do título de Mestre em Ciências.

Data: $22 / 11 / 2017$

\section{Banca Examinadora}

Profa. Dra. Elita Fontenele Urano de Carvalho

Instituição: IPEN

Julgamento: Aprovado

Profo. Dr. Thomaz Augusto Restivo Guisard Restivo

Instituição: UNISO

Julgamento: Aprovado

Profa. Dra. Claudia Terezinha Kniess

Instituição: UNINOVE

Julgamento: Aprovado 


\section{AGRADECIMENTO}

Ao Instituto de Pesquisas Energéticas e Nucleares, pela possibilidade de realizar este trabalho.

À Profa. Dra. Elita Fontenele Urano de Carvalho, pela orientação, apoio e conhecimento para realização deste trabalho.

À CAPES e à Eletronuclear pelo financiamento do projeto, por meio do edital CAPES/ Eletronuclear 012/2013.

Às Indústrias Nucleares do Brasil, pelo envio da matéria prima, em particular ao Eng. Diogo Costa Ribeiro, por contribuir com as discussões dos resultados obtidos.

Aos colegas do Centro de Combustível Nuclear do IPEN, que contribuíram nos resultados, em particular a Jorge Clementino dos Santos e João Batista da Silva Neto.

Aos colegas Alberto, Cadu, Gaspar, Maria, Mayara e Tânia, com quem compartilhamos as mesmas angústias e soluções.

Aos colegas do Centro de Célula a Combustível e Hidrogênio do IPEN pelo auxílio na caracterização por MEV e aos colegas do Centro de Ciência e Tecnologia de Materiais do IPEN pela caracterização da distribuição de tamanho de partícula.

Ao Dr. Michelangelo Durazzo pelo apoio e valiosas discussões em diversas etapas deste trabalho.

Ao Dr. Ricardo Mendes Leal Mendes Neto que me abriu inicialmente as portas do IPEN.

Ao Dr. Caio Palumbo de Abreu (amigo) que incentivou e proporcionou meu ingresso no programa de mestrado.

Aos colegas Andréia, Elaine, Gabriel Português, Marcos, Rodrigo, Shirley, e tantos outros que me incentivaram de diversas maneiras para que este trabalho pudesse ser terminado. 
À minha família, em especial aos meus pais, por todo apoio e companheirismo em mais essa etapa.

À minha companheira Tais Silva, que está sempre presente.

À todos que de alguma maneira contribuíram para este trabalho. 


\section{RESUMO}

\section{FREITAS, A. C., Estudo do processo de densificação de combustíveis urânio-érbio para}

reatores do tipo água leve. 2017. 90 p. Dissertação (Mestrado em Tecnologia Nuclear) Instituto de Pesquisas Energéticas e Nucleares - IPEN-CNEN/SP. São Paulo.

$\mathrm{O}$ processo de sinterização de pastilhas de $\mathrm{UO}_{2}-\mathrm{Er}_{2} \mathrm{O}_{3}$ tem sido investigado devido à sua importância na indústria nuclear e ao comportamento complexo durante a sinterização.

O presente estudo contempla o desenvolvimento de combustíveis nucleares para reatores de potência visando aumentar a sua eficiência no núcleo do reator por meio da elevação da taxa de queima. O érbio é indicado para ciclos mais longos, significando menos paradas para troca de combustível e menos rejeitos.

Neste trabalho foi estudado o uso de óxido de érbio variando as concentrações na faixa de 1-9,8\%, o qual foi adicionado ao pó de $\mathrm{UO}_{2}$ e ao lubrificante sólido ADS por meio de mistura mecânica, visando verificar a taxa de densificação e um possível bloqueio de sinterização. Os pós foram compactados e as pastilhas foram sinterizadas a $1700^{\circ} \mathrm{C}$ sob atmosfera de $\mathrm{H}_{2}$. Os resultados demonstram um característico bloqueio da sinterização no sistema $\mathrm{UO}_{2}-\mathrm{Er}_{2} \mathrm{O}_{3}$, porém de forma mais discreta do que no sistema $\mathrm{UO}_{2}-\mathrm{Gd}_{2} \mathrm{O}_{3}$, o qual ocorre no intervalo de temperatura de 1500 a $1700^{\circ} \mathrm{C}$, retardando a densificação. Os ensaios dilatométricos indicam uma retração de 21,87\% quando utilizado o $\operatorname{Er}_{2} \mathrm{O}_{3}$ a $1 \%$ de concentração em massa. Essa retração é maior do que as encontradas com concentrações superiores ou mesmo sem adição do veneno queimável, nos fornecendo um melhor grau de incorporação do elemento érbio, resultando em pastilhas com densidade adequada para uso como combustível nuclear.

Palavras chaves: Combustível nuclear, urânio, érbio, veneno queimável, densidade 


\begin{abstract}
FREITAS, A. C., Study of densification the uranium-erbium fuel for light water reactor. 2017. 90 p. Dissertation (Master in Nuclear Technology) - Institute of Nuclear Energy Research - IPEN-CNEN/SP. São Paulo.
\end{abstract}

The sintering process of $\mathrm{UO}_{2}-\mathrm{Er}_{2} \mathrm{O}_{3}$ pellets has been investigated because of its importance in the nuclear industry and the complex behavior during sintering. The present study includes the development of nuclear fuel for power reactor in order to increase the efficiency of the fuel through longer refueling intervals. The erbium is indicated for longer cycles, which means less stops to refueling and less waste.

In this work, it was studied the use of erbium oxide by varying the concentrations in the range of $1-9.8 \%$, which was added to $\mathrm{UO}_{2}$ powder through mechanical mixing, aiming to check the rate of densification and a possible sintering blockage. The powders were pressed and sintered at $1700^{\circ} \mathrm{C}$ under hydrogen atmosphere. The results show a sintering blockade in the $\mathrm{UO}_{2}-\mathrm{Er}_{2} \mathrm{O}_{3}$ system that occurs in the range of $1500-1700^{\circ} \mathrm{C}$ temperature. Dilatometric tests indicate a retraction of $21.87 \%$ when used $\mathrm{Er}_{2} \mathrm{O}_{3}$ at $1 \%$ mass concentration. This retraction is greater than is observed with higher concentrations or even without the addition of the burnable poison, providing us with a better degree of incorporation of the element erbium, resulting in pellets with density suitable for use as nuclear fuel.

Key words: nuclear fuel, uranium, erbium, burnable poison, density 


\section{TABELAS}

Tabela 1: Comparativo entre tipos de veneno queimável disponíveis .................................. 27

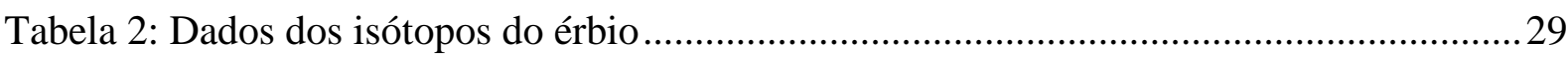

Tabela 3: Coeficientes da equação 3 para o érbio e gadolínio .................................................. 40

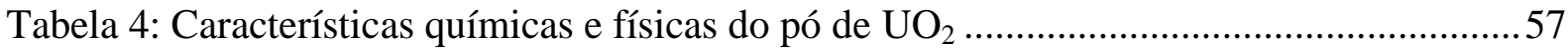

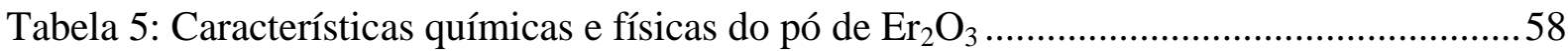

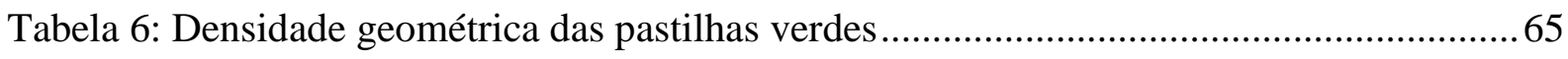

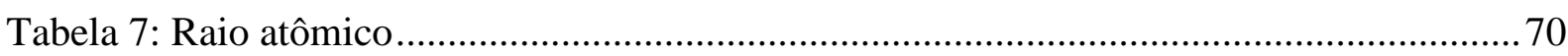




\section{FIGURAS}

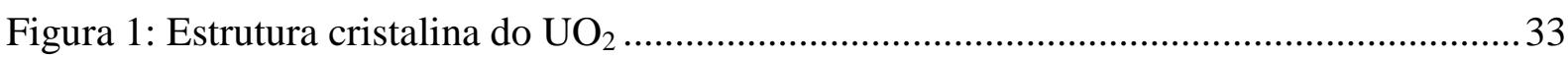

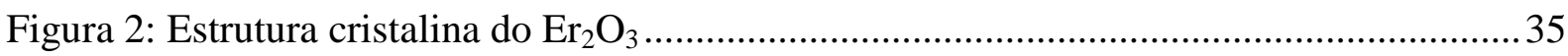

Figura 3: Transformação da microestrutura durante a sinterização ......................................... 37

Figura 4: Diminuição do parâmetro de rede da solução sólida (U,Gd) $\mathrm{O}_{2}$ e $(\mathrm{U}, \mathrm{Er}) \mathrm{O}_{2}$............. 38

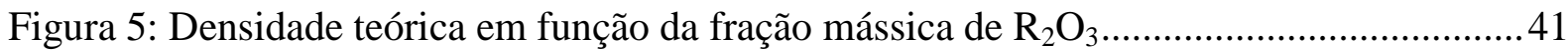

Figura 6: Diagrama de blocos do procedimento adotado ..................................................... 44

Figura 7: Dispositivo para extração da peça do ferramental de compactação..........................52

Figura 8: Dilatômetro vertical utilizado para sinterização ...................................................54

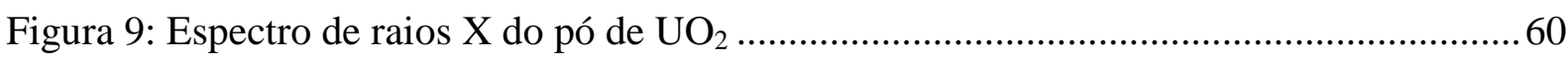

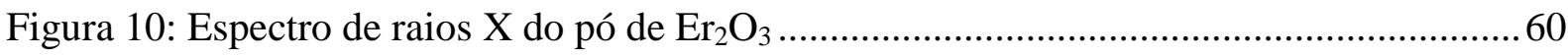

Figura 11: Micrografia do pó de $\mathrm{UO}_{2}$ por microscopia eletrônica de varredura .......................62

Figura 12: Micrografia do pó de $\mathrm{Er}_{2} \mathrm{O}_{3}$ por microscopia eletrônica de varredura.....................63

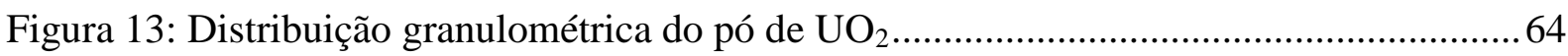

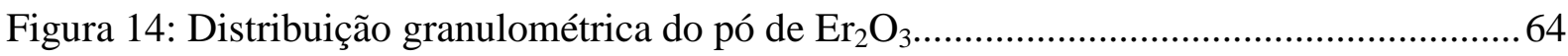

Figura 15: Curva de sinterização e taxa de retração da pastilha de $\mathrm{UO}_{2}$ puro..........................66

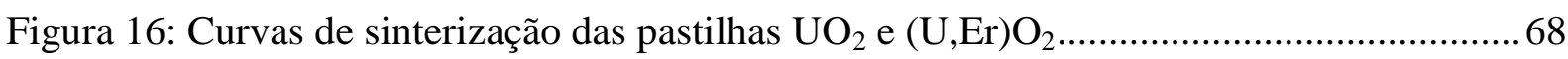

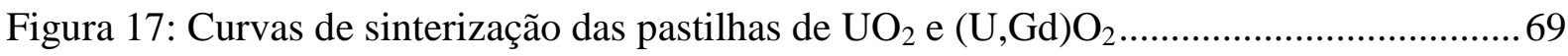

Figura 18: Taxa de retração das curvas de sinterização das pastilhas de $\mathrm{UO}_{2}$ e $(\mathrm{U}, \mathrm{Er}) \mathrm{O}_{2} \ldots \ldots . . .71$

Figura 19: Taxa de retração das curvas de sinterização das pastilhas de $\mathrm{UO}_{2}$ e $(\mathrm{U}, \mathrm{Gd}) \mathrm{O}_{2} \ldots . . .73$

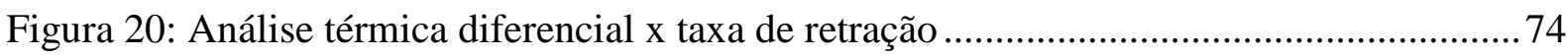

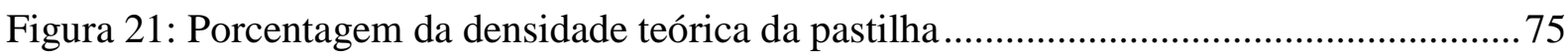

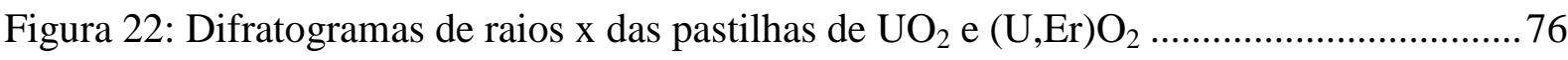

Figura 23: Micrografia eletrônica de varredura das pastilhas (a) $\mathrm{UO}_{2}$,

(b) $\mathrm{UO}_{2} .1,0 \% \mathrm{Er}_{2} \mathrm{O}_{3}$, (c) $\mathrm{UO}_{2} .2,5 \% \mathrm{Er}_{2} \mathrm{O}_{3}$, (d) $\mathrm{UO}_{2} .4,0 \% \mathrm{Er}_{2} \mathrm{O}_{3}$ e (e) $\mathrm{UO}_{2} .9,8 \% \mathrm{Er}_{2} \mathrm{O}_{3}$ 77 


\section{EQUAÇÕES}

Equação 1 - Parâmetro de rede da estrutura cristalina fluorita................................................ 33

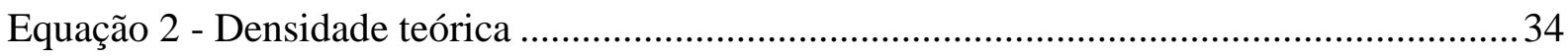

Equação 3 - Regressão linear do parâmetro de rede.................................................................. 39

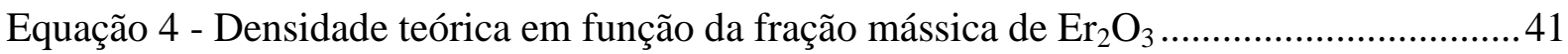

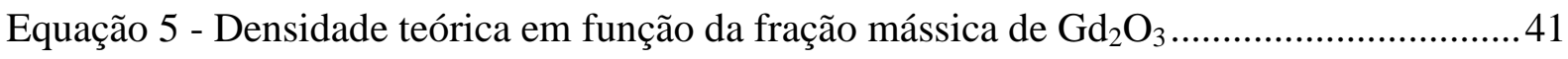

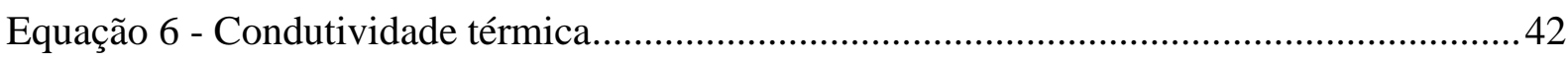

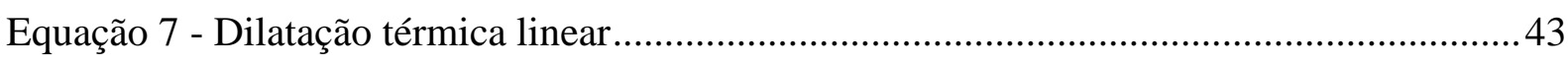

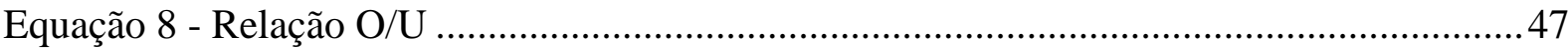

Equação 9 - Densidade teórica da mistura de pós ………........................................................52

Equação 10 - Volume do corpo sinterizado...............................................................................56

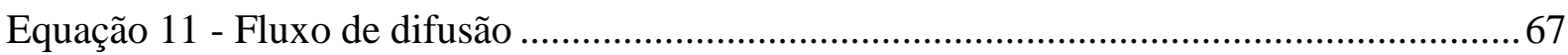




\section{SUMÁRIO}

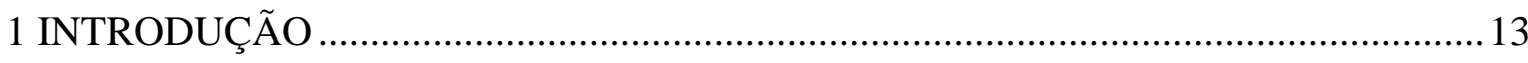

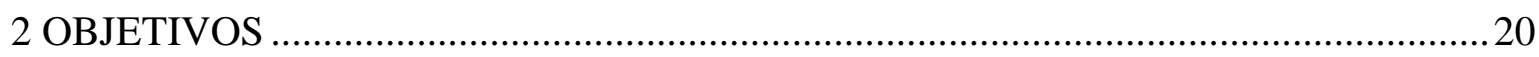

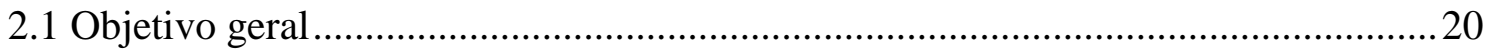

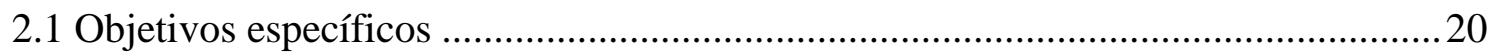

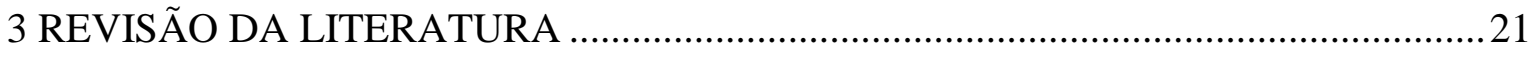

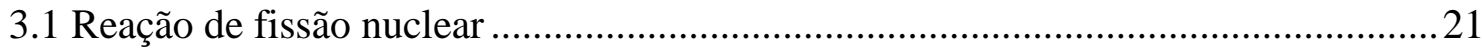

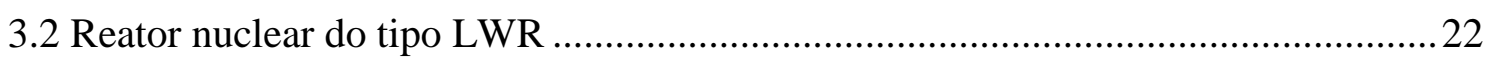

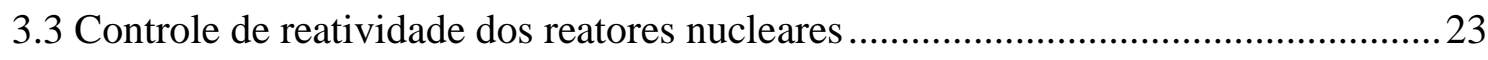

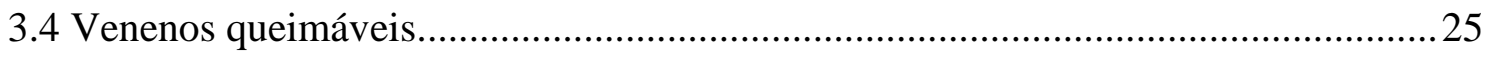

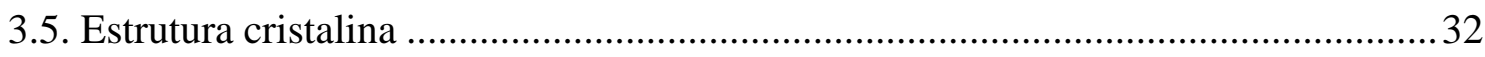

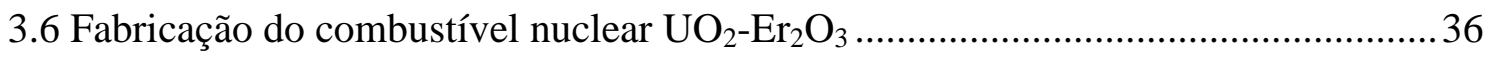

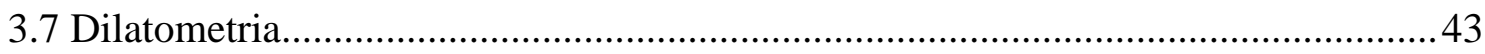

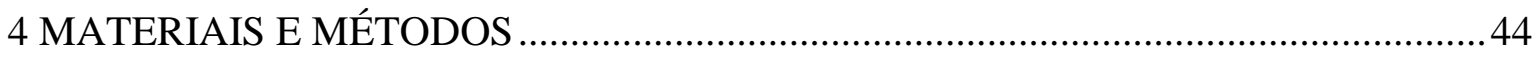

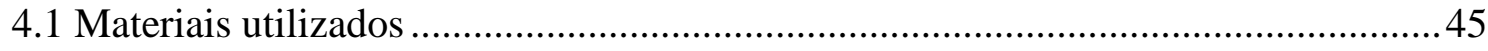

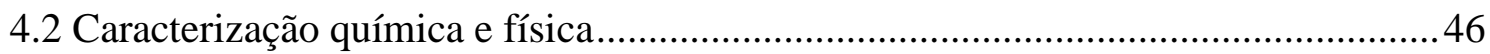

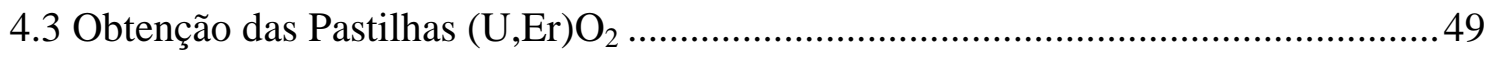

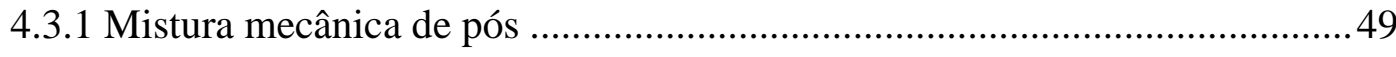

4.3.2 Compactação das pastilhas ................................................................. 50

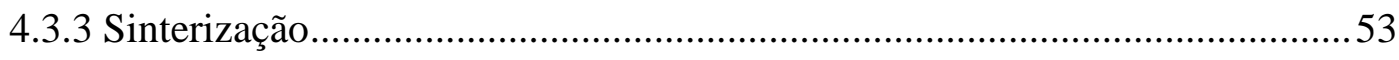

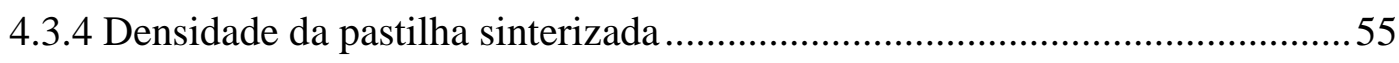

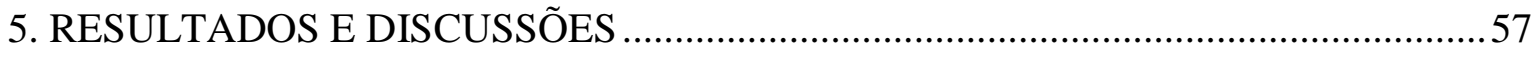

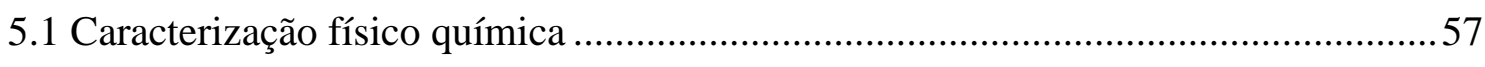

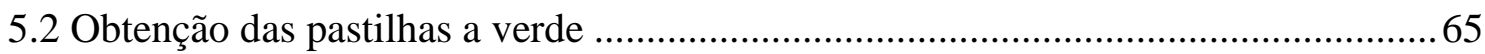




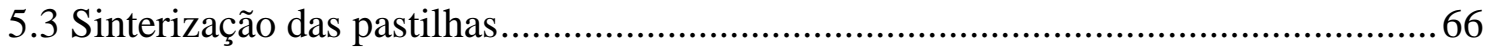

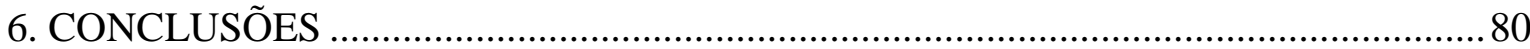

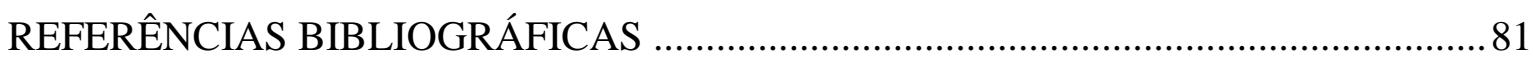

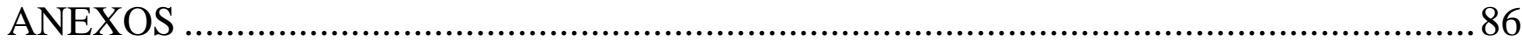




\section{INTRODUÇÃO}

É muito difícil imaginar nossa vida sem o advento da eletricidade. Muitas possibilidades surgiram que facilitam demasiadamente nosso dia a dia. $\mathrm{O}$ acesso à energia elétrica é hoje requisito básico de cidadania e, sem ele, o indivíduo fica marginalizado do que se entende por desenvolvimento ${ }^{11 /}$.

Para que a eletricidade seja democratizada é necessária uma grande ampliação de matrizes energéticas para se adaptar aos diferentes recursos disponíveis nas várias partes do mundo e assim atender à crescente demanda por energia.

Neste ponto encontra-se a energia nuclear, que vem se desenvolvendo para atender à demanda energética e melhorar sua eficiência. $\mathrm{O}$ primeiro reator nuclear foi colocado em operação por Enrico Fermi e seus colaboradores em $1942^{\prime 2 /}$, e o primeiro reator comercial no mundo foi o NPP Obninsk, na União Soviética, que começou a funcionar em $1954^{/ 3 /}$, dando origem a uma grande expansão da geração de energia elétrica por meio dessa matriz energética.

Em 2015 cerca de 438 reatores estavam em funcionamento em 30 países membros da International Atomic Energy Agency - IAEA, gerando um total de 379 gigawatts elétricos $\left(\mathrm{GW}_{\mathrm{e}}\right)$. No mesmo ano estavam em construção no mundo 68 reatores, com previsão de incremento de $67 \mathrm{GW}_{\mathrm{e}}^{/ 3 /}$, mostrando que há interesse da comunidade internacional em aumentar a produção de energia por meio da energia nuclear.

É esperado pela IAEA que em 2030 seja gerado através da energia nuclear até $632 \mathrm{GW}_{\mathrm{e}}$, principalmente na Ásia, motivado pelo crescimento econômico rápido, disponibilidade de recursos, segurança no fornecimento contínuo de energia e diversificação da matriz energética. Esses são fatores que motivaram o desenvolvimento da energia nuclear após a segunda guerra mundial e continuam sendo argumentos para a continuidade do desenvolvimento dessa matriz energética na década atual ${ }^{1 / 3}$. 
No Brasil, há 2 reatores nucleares em funcionamento, Angra I e Angra II, que geram 640 MW e 1350 MW respectivamente. Angra III, que se encontra em construção, tem como previsão a geração de 1405 MW de potência. Hoje, o potencial instalado de geração de energia pela matriz nuclear corresponde a cerca de $3 \%$ do total gerado no país, o que demonstra um potencial enorme de crescimento ${ }^{/ 4 /}$.

A principal matriz energética brasileira é constituída pelas usinas hidroelétricas, devido principalmente ao baixo custo e abundância de recursos minerais. Em 2015, a diversificação da matriz energética se mostrou importante devido à seca, que resultou na diminuição da capacidade de geração das usinas hidroelétricas, tendo como alternativa as usinas termoelétricas, queimando combustível fóssil para geração energia elétrica. Essa mudança sazonal durante o período de seca acarretou aumento da tarifa da energia elétrica para o consumidor, além da emissão de gás carbônico na atmosfera.

O projeto de um reator nuclear LWR (Light Water Reactor) está intimamente ligado à quantidade de energia gerada, produtos de fissão, rejeitos e tempo de vida útil. Um dos grandes desafios da indústria nuclear para diminuição do custo da geração de energia elétrica por meio da energia nuclear é o aumento do ciclo do combustível. Atualmente existem 68 geradores em construção ${ }^{13 /}$, buscando a otimização da utilização de recursos com uma nova geração de reatores, para tornar este feito possível.

Entre os meios que se encontra para aumentar o ciclo do combustível nuclear, otimizando seu custo, está o aumento da reatividade do combustível nuclear, que significa aumentar a proporção do isótopo ${ }^{235} \mathrm{U}$, que possui um núcleo mais instável e realiza a fissão com menos energia. A reação em cadeia se faz com esse isótopo, que libera em média 2,42 nêutrons ${ }^{15 /}$.

O tempo de vida de um combustível nuclear é o período em que o núcleo do reator possui excesso de reatividade para funcionar com potência suficiente para sustentar a reação nuclear. Além da reação nuclear ocorrida dentro do reator ser controlada, precisa ser autossustentada, o que faz com que o excesso de reatividade deva ser compensado convenientemente por elementos de controle ${ }^{/ 6 /}$.

Além de reduzir o custo da energia, outra vantagem de aumentar o ciclo do combustível é diminuir a quantidade de rejeitos radioativos, considerada um grande 
problema para a energia nuclear, uma vez que a sua implementação está ligada à aceitação pública. Quanto mais tempo tiver a vida útil do combustível, menos trocas serão necessárias, diminuindo a quantidade de rejeitos.

Os acidentes nucleares ocorridos em Chernobyl e mais recentemente, na usina nuclear de Fukushima Daiichi, geraram na sociedade um temor das instalações nucleares, o que pode ser vistos nos movimentos sociais que reivindicam a paralisação de plantas e a interrupção de programas de ampliação do setor para geração de energia. Além disso, as ameaças de guerra nuclear durante a guerra fria e as recentes ameaças de conflito entre países que detêm a tecnologia da bomba atômica contribuem para não aceitação de programas nucleares.

No Brasil, não há histórico de acidentes importantes com as usinas nucleares. Porém, em 2017 faz 30 anos que ocorreu o acidente nuclear de Goiânia, motivado pelo descomissionamento inadequado de um aparelho de radioterapia que continha o radioisótopo ${ }^{137} \mathrm{Cs}$. O desconhecimento sobre a energia nuclear, somado aos acidentes ocorridos ao longo do tempo e o temor da guerra fazem com que a implementação de um programa nuclear seja sensível à opinião pública.

Apesar dos aspectos negativos informados acima, outras aplicações da energia nuclear são cada vez mais conhecidas da sociedade. A irradiação de alimentos para aumento do tempo de decomposição, a irradiação de polímeros para melhora de propriedades físicas e, particularmente, seu uso na medicina nuclear, através de tratamentos contra o câncer e produção de radiofármacos. Se por um lado as experiências negativas afastam a opinião da sociedade sobre um programa nuclear, esses exemplos contribuem para o investimento nessa área.

O início da reação nuclear dentro do reator nuclear do tipo LWR ocorre por meio da absorção de um nêutron por um núcleo de um átomo de urânio ${ }^{235} \mathrm{U}$. Além da fragmentação do núcleo original, formando-se os produtos de fissão, são emitidos no processo de 2 a 3 novos nêutrons, gerando 4 a 9 novos nêutrons que, por sua vez, podem originar outras novas fissões e de 8 a 27 novos nêutrons, e assim, numa progressão geométrica, novos nêutrons podem ser produzidos, caracterizando-se uma reação em cadeia, gerando calor, utilizado para geração de energia elétrica. 
O controle da reação dentro do núcleo depende da população de nêutrons. $\mathrm{O}$ índice que mede essa relação é chamado fator de multiplicação k, que expressa a relação entre o número de nêutrons existentes no sistema num determinado ciclo de físsão e o número de nêutrons existentes no ciclo de fissão anterior. Se o valor do fator de multiplicação $\mathrm{k}$ for maior que 1 , o sistema é supercrítico, acarretando o aumento da população de nêutrons a cada ciclo, e consequentemente o número de reações de fissão nuclear. Se o k for menor que 1 , indica que a população de nêutrons diminui a cada novo ciclo e, mantendo essa estrutura, a vida útil do combustível será curta. E finalmente, se $\mathrm{k}$ for igual a 1, a população de nêutrons permanecerá a mesma a cada novo ciclo, se mantendo estável ${ }^{16 /}$.

$\mathrm{O}$ fator de multiplicação $\mathrm{k}$ diminui gradualmente durante a vida útil do combustível. Isso ocorre devido ao consumo do combustível e aos produtos de fissão que são formados durante as reações nucleares, que podem absorver nêutrons. Esses efeitos que ocorrem durante a queima do combustível precisam ser estudados, de modo que o fator de multiplicação k seja maior que 1 durante sua vida útil, e assim mantenha o excesso de reatividade $^{/ 6 /}$.

Como o fluxo de nêutrons não é constante no núcleo do reator, uma vez que depende localmente das condições de geração e absorção de nêutrons, sendo, portanto, uma função da posição no núcleo, ocorre uma distribuição de potência no núcleo do reator. Esta distribuição de potência varia ao longo da vida do núcleo do reator, acompanhando variações localizadas do fluxo de nêutrons devidas à dinâmica do balanço entre geração e absorção de nêutrons, ligadas ao consumo desigual do combustível e às variações das condições de absorção de nêutrons ao longo do tempo. Esta distribuição de potência ocorre tanto na direção radial como na direção axial do núcleo e é diferente para cada projeto ${ }^{15 /}$.

Dependendo da geometria do elemento combustível e do arranjo do núcleo do reator, ou seja, do espaçamento entre as varetas combustíveis e posições de barras de controle, ocorrem regiões onde o fluxo de nêutrons atinge valores máximos localizados. A estes picos de fluxo neutrônico correspondem picos de potência. É definido como fator de pico a relação entre a potência máxima local e a potência média do reator ${ }^{15 /}$. Este fator é importante no projeto do reator e está relacionado ao máximo excesso de reatividade permissível, impondo as limitações térmicas do projeto. 
O gerenciamento do combustível dentro do núcleo do reator que envolve o projeto do consumo, ou queima, do combustível e o padrão de recargas de combustível, ou seja, a retirada do combustível queimado e introdução de combustível novo exercem influência determinante no custo da energia gerada, uma vez que influenciam diretamente as atividades de gerenciamento do combustível fora do núcleo do reator, dentre as quais se podem citar o enriquecimento e a destinação final do combustível queimado como as mais importantes.

A otimização do uso do combustível depende principalmente do aumento na sua queima, aumentando-se o intervalo entre recargas. Para isso é necessário que o enriquecimento inicial do combustível deva ser aumentado para prover o núcleo com um excesso de reatividade extra necessária para manter o longo ciclo de queima. Isto significa que a quantidade adicional de material físsil no núcleo deve ser compensada pela introdução de uma maior quantidade de material absorvedor. Nos níveis de excesso de reatividade tradicionais dos reatores $\mathrm{LWR}$, em torno de 25 a $30 \%$ acima da requerida para a criticalidade, o controle deste excesso pode ser obtido por meio das barras de controle, venenos queimáveis tradicionais à base de boro e boro solubilizado no moderador e refrigerante $^{\mid 5 /}$.

A função do veneno queimável é basicamente controlar a população de nêutrons. Para tanto, o elemento químico empregado para essa função precisa capturar nêutrons decorrentes da fissão do urânio e o isótopo formado pela reação nuclear, não ${ }^{77 !}$. Sua presença no caroço do reator é necessária para controlar eficientemente o maior excesso de reatividade imposto pelo aumento da queima do combustível e da extensão do ciclo de queima.

O princípio do veneno queimável foi formulado por Radkowsky na década de 1970 e tem como principal requisito nuclear alta seção de choque de absorção de nêutrons, e os isótopos, produtos de transmutação, devem ter, contrariamente, uma seção de choque desprezível $^{/ 8 /}$. Em virtude dessa característica, é utilizado o termo queimável, pois esse material vai perdendo a capacidade de absorver nêutrons, ao mesmo tempo em que a reatividade do combustível vai diminuindo ${ }^{16 /}$. Esse balanço entre o consumo do combustível e a diminuição dos isótopos do veneno queimável capazes de absorver nêutrons garante o excesso de reatividade do reator, permitindo o prolongamento da sua vida útil e consequentemente é minimizada a geração de rejeitos radioativos. 
Os reatores de água leve (LWR) funcionam utilizando o dióxido de urânio $\mathrm{UO}_{2}$ - como combustível, onde as pastilhas combustíveis são produzidas pelo pó desse material. Uma forma de adicionar o veneno queimável ao combustível é o utilizando de forma integrada, ou seja, a pastilha combustível possui na sua composição o material absorvedor.

Um dos principais elementos químicos utilizados como veneno queimável é o gadolínio, pertencente à família das terras raras, que é adicionado ao combustível nuclear na forma de óxido $\left(\mathrm{Gd}_{2} \mathrm{O}_{3}\right)$, sendo este o material absorvedor utilizado nos reatores de Angra dos Reis. Outra possibilidade utilizada comercialmente é o érbio, também na forma de óxido, com fórmula química $\mathrm{Er}_{2} \mathrm{O}_{3}$.

O combustível $\mathrm{UO}_{2}-\mathrm{Gd}_{2} \mathrm{O}_{3}$ é amplamente utilizado em reatores de água leve. $\mathrm{O}$ gadolínio é um absorvedor de nêutrons muito forte e portanto pode reduzir o excesso de reatividade no primeiro ciclo de operação do reator. Atualmente o ciclo é de 15 a 18 meses e o conteúdo de $\mathrm{Gd}_{2} \mathrm{O}_{3}$ varia de 6 a $10 \%$ em peso, dependendo do ciclo. O prolongamento do ciclo é um dos métodos para aumentar a eficiência da operação do reator. Para um ciclo mais longo, $\mathrm{UO}_{2}-\mathrm{Er}_{2} \mathrm{O}_{3}$ deverá ser mais adequado que o $\mathrm{UO}_{2}-\mathrm{Gd}_{2} \mathrm{O}_{3}$, uma vez que o érbio é o absorvedor mais fraco.

Uma das formas de adicionar o $\mathrm{Er}_{2} \mathrm{O}_{3}$ é pela da mistura mecânica de pós, que é um método comercialmente mais atraente, devido principalmente à sua simplicidade ${ }^{\mid 9 /}$. Por outro lado, existe a necessidade de ter o controle da porosidade e alcançar a densidade especificada para uma pastilha combustível.

Este trabalho pretende avaliar a eficácia da incorporação do $\mathrm{Er}_{2} \mathrm{O}_{3}$ no combustível nuclear à base de $\mathrm{UO}_{2}$. Pelas características neutrônicas desse veneno queimável, pode-se prolongar a vida útil do combustível nuclear.

Através da revisão da literatura, pretende-se avaliar as propriedades neutrônicas do combustível $\mathrm{UO}_{2}-\mathrm{Er}_{2} \mathrm{O}_{3}$ e, experimentalmente, avaliar o comportamento desse mesmo combustível durante a sinterização. Sabe-se, através da literatura, que a incorporação do $\mathrm{Gd}_{2} \mathrm{O}_{3}$ diminui sensivelmente a retração da pastilha durante a sinterização, formando um bloqueio na sinterização, sendo necessário o uso de aditivos que favoreçam a 
densificação desse tipo de combustível, porém não há evidências na literatura se o bloqueio de sinterização ocorre quando há adição do óxido de érbio. 


\section{OBJETIVOS}

\subsection{Objetivo geral}

$\mathrm{O}$ presente trabalho objetiva estudar a densificação de pastilhas de $\mathrm{UO}_{2}$ dopadas com $\mathrm{Er}_{2} \mathrm{O}_{3}$ (óxido de érbio) no intervalo de 1 a 9,8\% em massa. Por meio deste estudo determina-se a taxa de densificação das pastilhas em função do teor de $\operatorname{Er}_{2} \mathrm{O}_{3}$, fixando a temperatura e tempo de sinterização, com auxílio da técnica de dilatometria.

\subsection{Objetivos específicos}

Estudar o comportamento da pastilha combustível de UO2 com 1,0\%, 2,5\%, $4,5 \%$ e $9,8 \%$ em massa de érbio, a influência do bloqueio de sinterização durante o processo de sinterização, e assim determinar o percentual de retração de cada pastilha, assim como suas respectivas densidades.

Com a análise dilatométrica será identificando a temperatura de solubilização do érbio na estrutura de $\mathrm{UO}_{2}$ 


\section{REVISÃO DA LITERATURA}

\subsection{Reação de fissão nuclear}

Os reatores nucleares utilizam a energia gerada a partir da fissão nuclear. Para entender o processo de fissão, pode-se utilizar o modelo de gota líquida. Nesse modelo, a gota existe graças a certa coesão entre as moléculas, o que acarreta a união no formato de gota num balanço entre as forças repulsivas de origem eletrostática e as forças de atração de origem na tensão superficial ${ }^{/ 10 /}$. É importante perceber que as moléculas da superfície possuem menos vizinhos que as moléculas do interior da gota. Quando se aplica alguma energia externa, dois eventos podem ocorrer: um, de algumas moléculas evaporarem, por causa da vibração da gota, e outro, a gota se dividir em gotas menores.

Quanto mais frágeis forem as forças de coesão dessa molécula, mais fácil será fazer a sua subdivisão. Exatamente por isso é utilizado o enriquecimento do urânio, que significa aumentar a proporção do isótopo ${ }^{235} \mathrm{U}$, que para realizar o processo de fissão precisa de menos energia, por ser um átomo mais instável.

O processo de fissão libera uma grande quantidade de energia. A energia liberada pela fissão do átomo ${ }^{235} \mathrm{U}$ é aproximadamente $200 \mathrm{MeV}$, e o valor da físsão de outros átomos pesados como ${ }^{233} \mathrm{U}$ e ${ }^{239} \mathrm{Pu}$ é similar ${ }^{/ 11,12 /}$. É essa energia que aquece o sistema, necessário para geração de eletricidade.

O modelo da gota líquida nos ajuda a entender didaticamente o processo de fissão nuclear. Essa divisão do núcleo do átomo não ocorre de forma simétrica, ou seja, os fragmentos da fissão não são iguais, podendo ter nos chamados produtos de fissão uma série extensa de produtos oriundos da divisão do átomo de urânio, em proporções variadas. A investigação dos produtos gerados pela fissão do ${ }^{235} \mathrm{U}$ possui desde o número de massa 66 , correspondente a um isótopo de crômio, até o número de massa 172, referente a um isótopo de gadolínio, gerando 106 produtos com número de massa diferente. Portanto, o 
núcleo ${ }^{235} \mathrm{U}$ é capaz de se dividir de 53 maneiras diferentes ${ }^{112 /}$, formando produtos como por exemplo, o ${ }^{135} \mathrm{Xe},{ }^{149} \mathrm{Sm}$ e ${ }^{151} \mathrm{Sm}$, que possuem a característica de absorver nêutrons ${ }^{15 /}$, o que diminuirá o fator de multiplicação $\mathrm{k}$.

O enriquecimento aumenta a reatividade do combustível nuclear, fazendo com que o fator de multiplicação k fique maior que 1 . Com a fissão do ${ }^{235} \mathrm{U}$ e a geração dos produtos de fissão capazes de absorver nêutrons, a reatividade vai diminuindo rapidamente e, consequentemente, a vida útil do combustível também. O veneno queimável controla a população de nêutrons, para que o número de fissões também seja controlado e, assim, prolongue a vida útil do combustível.

Além do fator de multiplicação k, outro parâmetro importante é o fator de potência, que é entendido como a razão entre a potência máxima local e a potência média do reator. Esse parâmetro é importante porque em algumas posições a potência sobe mais do que em as outras dentro do reator e dessa forma são necessárias ações para conter esse desequilíbrio ${ }^{15 /}$.

\subsection{Reator nuclear do tipo LWR}

Os reatores do tipo LWR são divididos em dois modelos: PWR (Pressure Water Reactor) e BWR (Boiling Water Reactor). Os reatores tipo PWR possuem um sistema de resfriamento de água primário, que retira o calor do núcleo, ilustrado de vermelho, e aquece um sistema secundário. No sistema secundário, a água muda de estado líquido para gasoso. A pressão do vapor de água faz a turbina movimentar e produzir eletricidade por meio do gerador. Os reatores brasileiros Angra I e II são equivalentes a esse tipo.

Os reatores tipo BWR se diferenciam pelo trocador de calor, não fazendo uso do sistema secundário. O contato da água com o caroço do reator faz com mude de estado líquido para gasoso, onde sua pressão é utilizada para movimentar a turbina.

Os projetos dos reatores se diferenciam pelo tipo de veneno queimável utilizado, a geometria do caroço do reator e o grau de enriquecimento do urânio. No caso dos reatores tipo LWR o teor de enriquecimento varia entre $2,50 \%$ e $4,95 \%{ }^{13 /}$. 
Com esse sistema, fica clara a necessidade de existir um controle robusto da reatividade para que não ocorra nenhum tipo de pico de aquecimento, levando a vazamentos ou acidentes mais graves.

\subsection{Controle de reatividade dos reatores nucleares}

A capacidade de absorção de nêutrons é determinada pela seção de choque. Ou seja, quanto maior a seção de choque, maior a probabilidade de interação do nêutron com a matéria, que no caso seria uma reação nuclear de captura de nêutron.

Para que a reação de fissão nuclear se mantenha controlada e autosustentável, é necessário uma série de estudos, dispositivos e projeto para que o combustível seja consumido de forma eficiente e segura dentro do reator nuclear.

O projeto de um reator nuclear prevê normalmente um excesso de reatividade para compensação do consumo do combustível e da formação de produtos de fissão que são fortes absorvedores de nêutrons, como o xenônio e o samário. O sistema de controle do reator tem a função de compensar e controlar este excesso de reatividade por meio da inserção e retirada de materiais absorvedores de nêutrons no interior do núcleo do reator, de forma a alterar os níveis de fluxo de nêutrons e, portanto, a potência, de acordo com o necessário e desejado. O sistema de controle serve também para modificar a distribuição de potência, deixando-o mais homogêneo e diminuindo os fatores de pico.

O excesso de reatividade inicial do combustível nuclear precisa ser compensado com reatividade negativa que possa ser controlada e ajustada, permitindo o prolongamento da vida útil do combustível ${ }^{17 /}$. Pode-se dividir o controle dos reatores em 3 categorias $^{15 /}$, como segue.

a) Barra de controle

As barras de controle são constituídas de materiais absorvedores, por isso, com alta seção de choque, e posicionadas em lugares estratégicos dentro do reator, para que o fator de potência não ultrapasse a limitação térmica do reator. A barra de controle permite 
a variação do valor de $\mathrm{k}$, alterando a população de nêutrons que contribuem com a reação nuclear.

Sua movimentação e posicionamento no interior do núcleo são realizados por meio de sistemas elétricos, pneumáticos ou hidráulicos. São utilizadas para ajustar a potência do reator e compensar variações de reatividade associadas com variações na temperatura do moderador e com o aparecimento de vazios. Pode-se dizer que as barras de controle exercem o controle fino do reator, isto é, providenciam a compensação de variações de reatividade de curta duração, ou seja, que ocorrem em pequenos intervalos de tempo quando comparados com a vida útil do núcleo do reator.

b) Barra de segurança

Como o próprio nome diz, o papel da barra de segurança é garantir que o reator nuclear interrompa a reação, ou seja, torne o valor de $\mathrm{k}$ menor que 1 , diminuindo consideravelmente a população de nêutrons, de modo que a reação não se sustente mais sozinha.

Essas barras permanecem fora do núcleo durante a operação normal do reator e, quando inseridas, o reator deve ficar subcrítico com uma margem de reatividade negativa estabelecida por normas. Essas barras são geralmente inseridas paralelamente ao eixo vertical do núcleo, o que permite, uma vez liberadas, sua rápida queda no interior do núcleo. Suas características físicas, incluindo os materiais absorvedores utilizados e os sistemas mecânicos, são normalmente idênticas às das barras de controle.

O material dessas barras deve ter grande capacidade de absorver nêutrons e, mesmo após a reação nuclear de captura de nêutrons, formarem novos isótopos que também possuam alta seção de choque de absorção. Os materiais mais usados e que possuem essa característica são o carbeto de boro - $\mathrm{B}_{4} \mathrm{C}$ e a liga $\mathrm{AgInCd}$, que possui a composição de $80 \%$ de prata, $15 \%$ de Índio e $5 \%$ de cádmio. Além do material utilizado, essas barras precisam ser posicionadas no reator, de modo que seu acionamento interrompa a reação rapidamente ${ }^{/ 5 /}$. 
c) Controlador fixo de longo prazo

É o sistema que é inserido de forma fixa no núcleo do reator com a finalidade de prover ajustes de variações de reatividade causadas por processos com um ciclo de tempo longo, como o consumo do combustível e o envenenamento pela formação de produtos de fissão com alta seção de choque de absorção de nêutrons. Pode-se dizer que este tipo de controle providencia a compensação de variações de reatividade de longa duração, ou seja, que ocorrem ao longo de toda a vida útil do núcleo do reator.

O controlador fixo de longo prazo é realizado por materiais conhecidos como veneno queimável. No caso das concepções mais atuais de combustíveis nucleares, é colocado de forma fixa e integrado ao combustível nuclear, de modo que absorva nêutrons e controle sua população em regiões estratégicas.

\subsection{Venenos queimáveis}

Com o contínuo desenvolvimento dos reatores nucleares surgiu outro importante uso para os materiais absorvedores de nêutrons, sendo introduzido de forma fixa em pontos estratégicos no núcleo do reator ou distribuído uniformemente no combustível, obtendo-se, assim, uma uniformidade na reatividade global do núcleo do reator durante sua vida útil, sendo projetado apropriadamente para ser consumido (ou queimado) a uma taxa aproximadamente igual à do combustível. Neste caso, o absorvedor é geralmente conhecido como veneno queimável e deve ter como principal característica a capacidade de absorver nêutrons gerando um isótopo que tenha baixa seção de choque de absorção, ou seja, produzir na reação de captura um isótopo que não possua capacidade de absorver nêutrons. Isto implica na gradativa perda da capacidade de absorção durante a operação do reator, acompanhando o consumo (ou queima) do combustível, daí derivando o termo "queimável", possibilitando um controle de longa duração da reatividade do núcleo do reator.

Do ponto de vista neutrônico, o veneno queimável deve atender principalmente a três critérios ${ }^{13 /}$ :

a) reatividade negativa inicial necessária para controlar a reatividade positiva inicial do caroço do reator; 
b) cinética de queima, que deve ser adaptada à do combustível de modo a obter o desaparecimento praticamente total do veneno quando o reator é desligado, isto é, minimização da intoxicação residual no final do ciclo;

c) controle de distribuição de potência ao longo da vareta combustível.

O estudo de novos tipos de combustíveis visa obter altas taxas de queima e consequentemente reduzir o custo total da energia nuclear. Para isso, é necessário combustível com alto enriquecimento, até $20 \%$, e a utilização de venenos queimáveis integrados. Como combustíveis com até $20 \%$ de enriquecimento no isótopo ${ }^{235} \mathrm{U}$ não é considerado material bélico nuclear, é então possível fundamentar um novo conceito de reator nuclear:

- Combustível com até $20 \%$ de enriquecimento no isótopo ${ }^{235} \mathrm{U}$;

- Veneno queimável integrado à base de terras raras $(\mathrm{Gd}, \mathrm{Sm}, \mathrm{Eu}, \mathrm{Dy}$

e Er).

Os principais venenos queimáveis utilizados comercialmente hoje são $\mathrm{Gd}_{2} \mathrm{O}_{3}$, $\mathrm{Er}_{2} \mathrm{O}_{3}$ e $\mathrm{ZrB}_{2}{ }^{/ 14 /}$, sendo que a gadolínia $\left(\mathrm{Gd}_{2} \mathrm{O}_{3}\right)$ é o principal material absorvedor utilizado como veneno queimável nos reatores tipo $\mathrm{LWR}^{/ 6 /}$. Na tabela 1 , pode-se ter um comparativo entre os 3 venenos queimáveis mais utilizados. $\mathrm{O}$ sistema $\mathrm{UO}_{2}-\mathrm{Er}_{2} \mathrm{O}_{3}$, o sistema $\mathrm{UO}_{2}$ $\mathrm{Gd}_{2} \mathrm{O}_{3}$ e as pastilhas revestidas com $\mathrm{ZrB}_{2}$, que também é utilizado comercialmente.

Os venenos queimáveis $\mathrm{Er}_{2} \mathrm{O}_{3}$ e $\mathrm{Gd}_{2} \mathrm{O}_{3}$ possuem grandes semelhanças. Além dos elementos gadolínio e érbio pertencerem à família das terras raras, seus óxidos possuem semelhanças quanto a estrutura cristalina, valência e a forma de ser adicionado ao $\mathrm{UO}_{2}$. Como o érbio tem uma seção de choque menor que o gadolínio, é necessário utilizálo em um grande número de varetas ${ }^{\prime 13,14 /}$, cerca de $20 \%$ a $30 \%$, porém na proporção de $1 \%$ a 2,5\% em peso nas pastilhas. No caso da gadolínia, os combustíveis comerciais utilizam uma proporção de $6 \%$ a $10 \%$ em peso nas pastilhas, afetando algumas propriedades do combustível e uma proporção de $3 \%$ a $6 \%$ de varetas contendo essa composição.

A vantagem da érbia sob a gadolínia é um baixo impacto nas propriedades do combustível (condutividade térmica e ponto de fusão), devido à baixa concentração nas pastilhas combustível e um bom controle do coeficiente de temperatura do moderador. A desvantagem se deve principalmente a uma penalidade no fim de ciclo $^{114,15 /}$, que se deve a um alto efeito de captura neutrônica pela contínua formação do isótopo ${ }^{167} \mathrm{Er}$. 
Tabela 1: Comparativo entre tipos de veneno queimável disponíveis

\begin{tabular}{|c|c|c|c|}
\hline Tipo & $U O_{2}-G d_{2} O_{3}$ & $\mathrm{ZrB} \mathrm{B}_{2}$ & $U \mathrm{O}_{2}-\mathrm{Er}_{2} \mathrm{O}_{3}$ \\
\hline Fabricantes & (a) & Westinghouse (USA) & $\begin{array}{l}\text { Combustion Eng } \\
\text { Co. (USA) }\end{array}$ \\
\hline Concentração & $6-10 \%$ em peso & - & $1-2,5 \%$ em peso \\
\hline $\begin{array}{l}\text { Diminuição na condutividade } \\
\text { térmica }\end{array}$ & Significativa & Negligenciável & Pequena \\
\hline $\begin{array}{l}\text { Redução na temperatura de } \\
\text { fusão }\end{array}$ & Significativa & Negligenciável & Pequena \\
\hline $\begin{array}{l}\text { Proporção de varetas por } \\
\text { elemento combustível }\end{array}$ & $3-6 \%$ & $30-40 \%$ & $20-30 \%$ \\
\hline $\begin{array}{l}\text { Redução da massa de }{ }^{235} \mathrm{U} \text { no } \\
\text { elemento combustível }\end{array}$ & Pequena & Negligenciável & Pequena \\
\hline Velocidade de queima & Alta & Alta & Média \\
\hline $\begin{array}{l}\text { Reatividade residual no final } \\
\text { do ciclo de queima }\end{array}$ & Pequena & Negligenciável & Significativa \\
\hline $\begin{array}{l}\text { Distribuição de potência na } \\
\text { vareta de veneno queimável }\end{array}$ & Boa & Satisfatória (b) & Boa \\
\hline Pico de potência localizado & Significativo & Pequeno & Pequeno \\
\hline $\begin{array}{l}\text { Controle do coeficiente de } \\
\text { temperatura do moderador }\end{array}$ & Bom & Satisfatório & Ótimo \\
\hline Facilidade de fabricação & $\begin{array}{l}\text { Pequena variação } \\
\text { na linha padrão }\end{array}$ & $\begin{array}{c}\text { Grande equipamento } \\
\text { adicional }\end{array}$ & $\begin{array}{c}\text { Pequena variação } \\
\text { na linha padrão }\end{array}$ \\
\hline $\begin{array}{l}\text { Reprocessabilidade do } \\
\text { combustível com o veneno } \\
\text { queimável }\end{array}$ & Boa & Questionável & Boa \\
\hline
\end{tabular}

(a) Franco-Belge de Fabrication du Combustible (França e Bélgica), Siemens AG (Alemanha), Fabricazione Nucleari (Itália), Japan Nuclear Fuel (Japão), Mitsubishi Nuclear Fuel \& Nuclear Fuel Industries (Japão), Korean Nuclear Fuel Company (Koreia), Empresa Nacional del Uranio AS (Espanha), ASEA-ATOM (Suécia), British Nuclear Fuels BNFL (Inglaterra), TENEX-Novosibirsk-Ulbinskij (Rússia/Kazaquistão), Babcock $\&$ WilcoxFuel (USA), General Electric (USA) e Siemens Power (USA).

(b) Devido à rápida queima.

Fonte: IAEA - Tecdoc-844, 1995. 
A utilização do $\mathrm{ZrB}_{2}$ consiste na deposição de uma fina camada na superfície da pastilha, sendo portanto, necessárias mudanças na rota de fabricação da pastilha combustível. Nesse caso, os fatores de pico são ajustados distribuindo as pastilhas na vareta combustível $^{/ 14 /}$. Sua principal vantagem é sua menor absorção residual no fim do ciclo de queima e a desvantagem é seu custo, devido principalmente ao modo de incorporação ao $\mathrm{UO}_{2}{ }^{15 /}$.

Outros elementos pertencentes ao grupo das terras raras (Sm, Dy, Eu) também podem ser utilizados como veneno queimável. Ocorre que o samário, disprósio e európio possuem longas cadeias de absorção de nêutrons, formando isótopos que também possuem alta seção de choque. Essa característica dificulta sua utilização, uma vez que forma uma absorção residual no fim do ciclo inaceitável ${ }^{15 /}$.

Na tabela 2, apresentam-se os dados referentes aos isótopos do érbio, assim como sua abundância. Sua análise indica uma sensível diferença entre as seções de choque dos seus isótopos. O isótopo ${ }^{167}$ Er é o principal responsável pela captura de nêutron, já que possui uma seção de choque no valor de 654,80 barns para nêutrons térmicos. Os outros isótopos possuem valores menos significativos, porém o ${ }^{167} \mathrm{Er}$ é continuamente produzido durante a queima, por meio da captura de nêutrons do ${ }^{166} \mathrm{Er}$, podendo ocasionar uma perda de reatividade no fim do ciclo. Esse efeito é sentido principalmente em ciclos muito longos. Uma forma de diminuir a penalidade do fim do ciclo é o enriquecimento do érbio em ${ }^{167} \mathrm{Er}$ aumentando a eficiência do combustível, a tal ponto que viabiliza economicamente a produção do érbio isotopicamente modificado ${ }^{15 /}$.

$\mathrm{Na}$ década de 70, Radkowski publicou um artigo colocando a érbia $\left(\mathrm{Er}_{2} \mathrm{O}_{3}\right)$ como alternativa de veneno queimável nos reatores tipo LWR. Na década de 80 a empresa Combustion Engineering (CE) conduziu estudos para efetivamente substituir a gadolínia por esse novo veneno queimável. Sendo assim, em 1991 foram realizados testes com 56 varetas contendo o veneno queimável érbio, com 1,5\%, para obtenção de dados para utilização desse material em escala industrial $^{18 /}$. 
Tabela 2: Dados dos isótopos do érbio

\begin{tabular}{cccc}
\hline $\begin{array}{c}\text { Composição do } \\
\text { isótopo natural }\end{array}$ & $\begin{array}{c}\text { Abundância } \\
(\%)\end{array}$ & $\begin{array}{c}\text { Seção de choque de } \\
\text { captura térmica } \\
(\mathrm{b})\end{array}$ & $\begin{array}{c}\text { Seção de choque } \\
\text { total (b) }\end{array}$ \\
\hline${ }^{162} \mathrm{Er}$ & 0,1 & 29,18 & 574,83 \\
${ }^{164} \mathrm{Er}$ & 1,6 & 13,25 & 144,71 \\
${ }^{166} \mathrm{Er}$ & 33,6 & 20,81 & 110,00 \\
${ }^{167} \mathrm{Er}$ & 23,0 & 654,80 & $3.906,60$ \\
${ }^{168} \mathrm{Er}$ & 26,8 & 2,78 & 40,56 \\
${ }^{170} \mathrm{Er}$ & 14,9 & 5,91 & 58,57 \\
\hline
\end{tabular}

Fonte: Barchevtsev, V., Artisyuk, V., Ninokata, H., 2002/16/

Para reatores $\mathrm{PWR}$, o $\mathrm{Er}_{2} \mathrm{O}_{3}$ é diretamente homogeneizado com o $\mathrm{UO}_{2}$, porém em proporções inferiores às utilizadas no caso do $\mathrm{Gd}_{2} \mathrm{O}_{3}$ (apenas 1 a 2,5\% em peso). A ABB-Combustion Engineering adotou o érbio após a implantação de um programa experimental que demonstrou que as propriedades do combustível com érbio são muito parecidas com as do combustível com gadolínio, podendo este combustível se beneficiar da extensa base de dados existente para o $\mathrm{UO}_{2}-\mathrm{Gd}_{2} \mathrm{O}_{3}$. Quatro elementos combustíveis contendo érbio foram irradiados no reator San Onofre 2 para validação da metodologia de cálculo do projeto com resultados satisfatórios ${ }^{177}$.

O érbio possui seção de choque de absorção de nêutrons similar à do boro e suas características de absorção permitem flexibilidade no controle do coeficiente de temperatura do moderador. Com o uso do érbio, as amplas variações do fluxo de nêutrons com a queima, observadas no caso do gadolínio, são evitadas ${ }^{/ 18 /}$. O érbio tem sido usado nos reatores de pesquisas tipo TRIGA desde 1974 e tem se mostrado confiável e previsível.

Asou e Porta ${ }^{/ 13 /}$ sugeriram que o gadolínio é mais apropriado para aplicação como veneno queimável integrado para ciclos de queima de até 18 meses, enquanto o 
érbio, também como veneno queimável integrado, é indicado para uso em ciclos de queima muito longos, de 24 meses ou maiores, presente em menores concentrações e distribuído num número maior de varetas. Além disto, devido ao efeito do érbio no coeficiente de temperatura do moderador, ele permite a utilização do boro solúvel em concentrações superiores à máxima admitida com o uso do gadolínio. Análises de custos indicam que o veneno queimável a base de érbio é competitivo com o $\mathrm{ZrB}_{2}{ }^{19 /}$.

Em virtude do projeto do reator, a reatividade inicial do combustível pode ser aumentada, introduzindo uma quantidade maior de material absorvedor, contendo a população de nêutrons gerada em decorrência disso. $\mathrm{O} \mathrm{Er}_{2} \mathrm{O}_{3}$ pode ser utilizado para cumprir esse papel, devido principalmente a um dos isótopos do érbio $\left({ }^{167} \mathrm{Er}\right)$ possuir alta seção de choque para captura de nêutrons térmicos, conforme a tabela 2 mostra.

A mistura de $1 \%$ do érbio traz pequenas modificações nas propriedades do dióxido de urânio ${ }^{16,20 /}$. Modificando isotopicamente e considerando que o érbio possua apenas o isótopo ${ }^{167} \mathrm{Er}$, à adição de $1 \%$ do érbio verifica-se que o fator $\mathrm{k}$ máximo diminui de 1,67 para 1,45. Quando se adiciona $4 \%$ de ${ }^{167} \mathrm{Er}$, esse fator diminui para 1,4, porém há uma perda de reatividade no início da queima ${ }^{16 /}$.

O Departamento de Energia dos EUA fez um estudo sobre a performance neutrônica dos principais venenos queimáveis $\left(\mathrm{ZrB}_{2}\right.$, gadolínio, samário, érbio, disprósio, európio e háfnio). No caso do érbio, foi estudado em mistura do pó de $\mathrm{UO}_{2} \operatorname{com} \mathrm{Er}_{2} \mathrm{O}_{3}$, na proporção de $2 \%, 4 \%, 8 \%$ e $12 \%$, sendo que, em situações em que as pastilhas contendo o veneno queimável não estavam presentes em todas as varetas do reator, foi utilizado até $16 \%$. Os resultados obtidos indicam que existe uma vantagem clara na utilização do érbio, enriquecido com o isótopo ${ }^{167} \mathrm{Er}$, tanto sob o ponto de vista da taxa de reatividade inicial, como na penalidade do fim do ciclo. Além disso, o enriquecimento do érbio permite que possa ser utilizada uma fração mássica menor ${ }^{21 /}$.

Outra análise foi realizada com o combustível nuclear enriquecido a taxas próximas a $20 \%$. A alta queima abre possibilidades para aumentar a vida do combustível ao nível da própria vida útil do reator. Barchevtsev, Artisyuk e Ninokata ${ }^{16 /}$, estudaram um combustível a base de $\mathrm{UO}_{2}$ enriquecido a 19,8\% (como é conhecido, urânio com fração de ${ }^{235} \mathrm{U}$ superior a $20 \%$ é tratado como material bélico), utilizando o érbio como veneno queimável. Os autores justificam que esse tipo de combustível requer uma porosidade 
inicial de $15 \%$ e o revestimento de aço inox, para suportar a alta pressão de gases oriundos do produto de fissão. $\mathrm{O}$ excesso de reatividade é suprimido pelo érbio, adicionado na forma de $\mathrm{Er}_{2} \mathrm{O}_{3}$ e analisado a sua eficiência pelo fator $\mathrm{k}$. Com a adição de $4 \%$ de ${ }^{167} \mathrm{Er}$ em U $\left(19,8 \%{ }^{235} \mathrm{U}\right)$, o fator k diminui de 1,67 para 1,4 . Quando se adiciona o érbio, numa mistura isotópica de 5,8\% 166Er e 4,0\% 167Er, o fator k chega em 1,05, que estaria dentro da faixa especificada para queima do combustível.

Um exemplo prático sobre a utilização do érbio como veneno queimável é o reator Ignalina Nuclear Power Plant NPP (Lituânia), que era operado com 2,0\% ${ }^{235} \mathrm{U}$ enriquecido e teve essa porcentagem aumentada para 2,8\% com o érbio natural sendo usado como veneno queimável ${ }^{122 /}$. Esse exemplo mostra a viabilidade econômica do érbio como veneno queimável, tanto isotopicamente modificado, como na forma natural.

A adição do veneno queimável nas pastilhas combustíveis segue diferentes roteiros na literatura, podendo ser feita pela mistura mecânica ${ }^{19,23,24 /}$, moagem ${ }^{125 /} \mathrm{e}$ coprecipitação $^{123,24,25 /}$. Essas técnicas sugerem graus de homogeneidade diferente que interferem na sinterização da mistura, no entanto, a mistura mecânica de pós é o processo mais utilizado ${ }^{15 /}$ e a INB (Indústrias Nucleares do Brasil) a utiliza para realizar suas misturas $^{26 /}$. Sua simplicidade traz vantagens econômicas, tornando a fabricação do elemento combustível mais barata.

A homogeneidade da mistura de pós é importante, pois em casos de misturas de pós não suficientes, não há dissolução completa do $\mathrm{Er}_{2} \mathrm{O}_{3}$ na matriz de $\mathrm{UO}_{2}$, formando uma composição dispersa heterogênea. Essa composição heterogênea faz com que ocorram diferentes retrações ao longo da pastilha durante a sinterização, acompanhado de inclusões ${\text { e } \text { trincas } / 27 /}$.

A temperatura de sinterização também é outro fator que influencia o comportamento da pastilha. Na literatura, são usadas temperaturas que variam entre $1650^{\circ} \mathrm{C}^{/ 23 /} \mathrm{e} 1760^{\circ} \mathrm{C}^{/ 26 /}$. Apesar do ciclo térmico da INB utilizar este último valor, há evidência na literatura da formação da solução sólida a $1700^{\circ} \mathrm{C}$, por meio da mistura mecânica de pós de $\mathrm{UO}_{2}$ e $\mathrm{Er}_{2} \mathrm{O}_{3}{ }^{120 /}$.

$\mathrm{Na}$ literatura existe poucos trabalhos avaliando o combustível $\mathrm{UO}_{2}-\mathrm{Er}_{2} \mathrm{O}_{3}$, diferentemente do que ocorre com o combustível $\mathrm{UO}_{2}-\mathrm{Gd}_{2} \mathrm{O}_{3}$. Acredita-se que o maior 
interesse da comunidade científica pelo combustível à base de $\mathrm{UO}_{2}$, utilizando a gadolínea como veneno queimável, se deva principalmente ao fato da sua utilização ser usada em maior escala, tendo em vista que há maior variedade de fornecedores que fabricam combustíveis nucleares com veneno queimável integrados, conforme visto na tabela 1.

Embora as similaridades coloquem o $\mathrm{Er}_{2} \mathrm{O}_{3}$ como concorrente direto do $\mathrm{Gd}_{2} \mathrm{O}_{3}$, análises de custo indicam que esse veneno queimável é competitivo apenas com o $\mathrm{ZrB}_{2}{ }^{/ 19 /}$ e caso ocorra uma mudança drástica da substituição das recargas de todos os reatores, seria necessário um incremento da produção mundial do óxido de érbio entre 20 e $50 \%{ }^{114 /}$.

Esses fatores contribuem para que o volume de artigos na literatura sobre o combustível $\mathrm{UO}_{2}-\mathrm{Er}_{2} \mathrm{O}_{3}$ seja menor, porém torna significativa a necessidade de maiores estudos sobre o assunto, uma vez que o aumento do ciclo é importante para otimização do combustível nuclear.

\subsection{Estrutura cristalina}

$\mathrm{O}$ pó de $\mathrm{UO}_{2}$ pode ser fabricado pela redução do $\left(\mathrm{NH}_{4}\right)_{4} \mathrm{UO}_{2}\left(\mathrm{CO}_{3}\right)_{3}$ (tricarbonato de amônio uranilo - TCAU) ou $\left(\mathrm{NH}_{4}\right)_{2} \mathrm{U}_{2} \mathrm{O}_{7}$ (diuranato de amônio - DUA), que recebem um tratamento térmico, com atmosfera redutora, para formar o dióxido de urânio $^{15,6,28 /}$. O processo TCAU apresenta uma vantagem importante sobre o processo DUA, pois o pó de $\mathrm{UO}_{2}$ obtido pode ser compactado diretamente, não sendo necessárias etapas de moagem, pré-compactação, e peneiramento. A área de superfície específica atingida por essa rota também permite uma boa sinterabilidade ${ }^{16 /}$.

$\mathrm{O} \mathrm{UO}_{2}$ possui estrutura cristalina do tipo fluorita, tipo $\mathrm{CaF}_{2}$, onde os átomos de urânio formam uma estrutura cúbica de face centrada (CFC) e o oxigênio forma uma estrutura cúbica. A figura 1 representa essa estrutura, onde as bolas de cor azul representam os átomos de urânio e as bolas de cor vermelha representam os átomos de oxigênio.

Com essa figura, pode-se deduzir a equação 1, onde um quarto da diagonal principal do cubo formado pela estrutura cristalina fluorita é composta pelo raio do cátion e do ânion. 
Figura 1: Estrutura cristalina do $\mathrm{UO}_{2}$

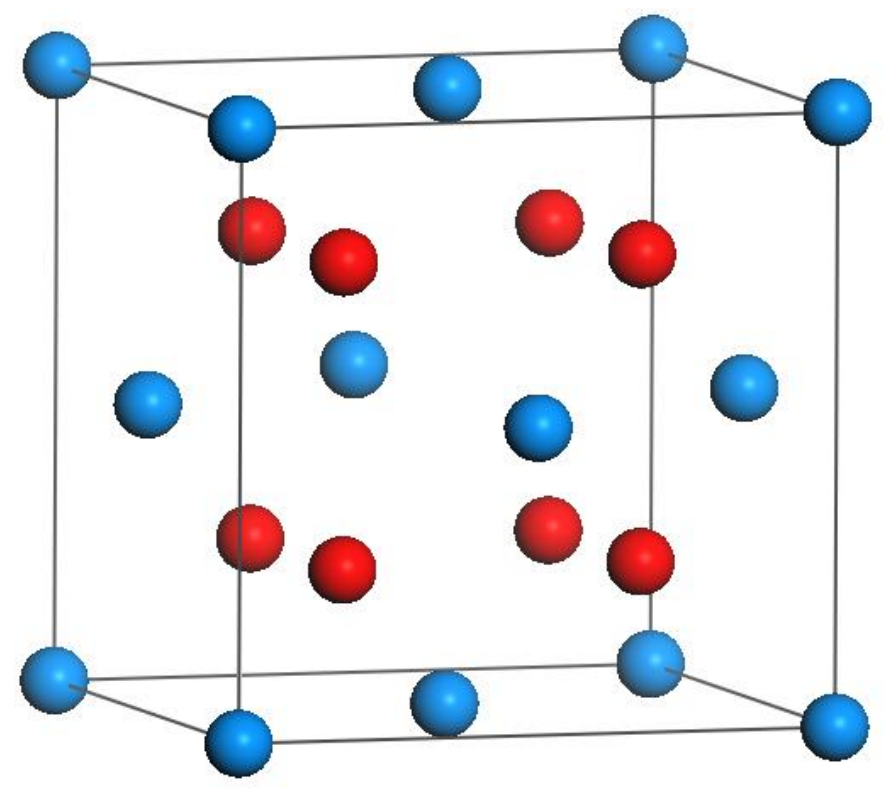

Fonte: Seach \& Match - ficha 76-1118 ${ }^{/ 29 /}$

$$
\begin{gathered}
\frac{1}{4} d=\frac{a \sqrt{3}}{4} \\
\left(r_{\text {cation }}+r_{\text {anion }}\right)=\frac{a \sqrt{3}}{4} \\
\mathrm{a}=\frac{4}{\sqrt{3}}\left(\mathrm{r}_{\text {cation }}+\mathrm{r}_{\text {anion }}\right)
\end{gathered}
$$

Onde,

d: diagonal principal do cubo

a: parâmetro de rede

$\mathrm{r}_{\text {cátion: }}$ : raio atômico do $\mathrm{U}^{4+}$

$\mathrm{r}_{\text {ânion: }}$ : raio atômico do $\mathrm{O}^{2-}$ 
Sendo o valor dos raios iônicos do $\mathrm{U}^{4+}$ e $\mathrm{O}^{2-}$ de $0,10011 \mathrm{~nm}$ e $0,13675 \mathrm{~nm}$ respectivamente, e substituindo na equação 1, determina-se o valor teórico do parâmetro de rede do $\mathrm{UO}_{2}$ de $0,5470 \mathrm{~nm}^{130 /}$.

A densidade teórica (Dt) do $\mathrm{UO}_{2}$ pode ser calculada usando a equação $2^{1 / 31 /}$.

$$
D t=\frac{\sum(n A)}{V * N_{A}}
$$

Onde,

$\Sigma(\mathrm{nA})$ : somatória da massa molar

V: Volume da célula unitária

$\mathrm{N}_{\mathrm{A}}$ : número de Avogrado

Substituindo os valores conhecidos, e ajustando as unidades necessárias, temos a densidade teórica do $\mathrm{UO}_{2}$, aceita na literatura.

$$
\begin{gathered}
D t=\frac{(4 * 238+8 * 16)}{\left(1,6367 * 10^{-28} * 6.023 * 10^{23}\right)} \\
D t=10,96 \mathrm{~g} / \mathrm{cm}^{3}
\end{gathered}
$$

$\mathrm{O} \mathrm{UO}_{2}$ pode absorver íons de oxigênio a baixas temperaturas, fazendo com que mude a razão estequiométrica $\mathrm{O} / \mathrm{U}$. A incorporação do oxigênio na forma de $\mathrm{O}^{2-}$ na estrutura cristalina do $\mathrm{UO}_{2}$ é possível porque o urânio (cátions) pode assumir valência +4 , +5 e +6 , permitindo a neutralidade eletrônica. Os cátions com valência +5 e +6 possuem raio atômico menor que o $\mathrm{U}^{4+}$, que faz com que o parâmetro de rede e o volume da célula unitária diminuam $^{1 / 30 /}$. Portanto, aumentando a relação $\mathrm{O} / \mathrm{U}$, ocorre a diminuição do parâmetro de rede, e consequentemente, a diminuição da densidade teórica do $\mathrm{UO}_{2}{ }^{228 /}$. 
A determinação da razão estequiométrica $\mathrm{O} / \mathrm{U}$ no $\mathrm{UO}_{2}$ é um parâmetro importante na qualificação do combustível nuclear. Sabe-se que o $\mathrm{UO}_{2}$ se desvia facilmente da estequiometria, transformando-se em óxido superior do tipo $\mathrm{UO}_{2+\mathrm{x}}$ ao absorver oxigênio da atmosfera. O desvio da estequiometria pode ser analisado sob dois aspectos diferentes: $\mathrm{UO}_{2}$ em fase de sinterização e $\mathrm{UO}_{2}$ como elemento combustível. Sob o primeiro aspecto nota-se que um ligeiro desvio da estequiometria favorece a sinterização, chegando-se a obter pastilhas de maiores densidades. Sob o segundo aspecto, um desvio da estequiometria é pernicioso para o $\mathrm{UO}_{2}$ como combustível nuclear, já que sua condutividade térmica diminui sensivelmente com este desvio. Apesar desses dois aspectos contrastantes, a relação $\mathrm{O} / \mathrm{U}$ diminui com a sinterização. Assim, é interessante que a relação $\mathrm{O} / \mathrm{U}$ do pó para a compactação e sinterização seja ligeiramente não estequiométrica do tipo $\mathrm{UO}_{2+\mathrm{x}}$.

$\mathrm{O} \mathrm{Er}_{2} \mathrm{O}_{3}$ tem uma estrutura mais complexa, não possuindo um grau de repetição claro como a estrutura cristalina formada pelo $\mathrm{UO}_{2}$. Na figura 2, é mostrado sua estrutura, que é cúbica de corpo centrado. A densidade teórica desse material é 8,64 g/ $\mathrm{cm}^{3}$, conforme a literatura $^{21 /}$.

Figura 2: Estrutura cristalina do $\mathrm{Er}_{2} \mathrm{O}_{3}$

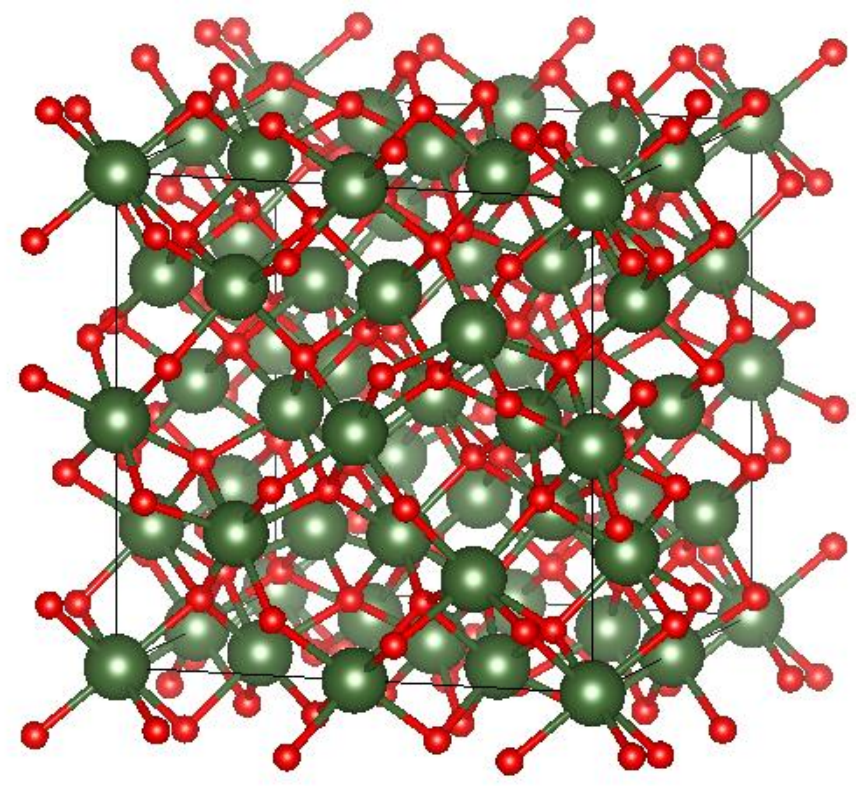

Fonte: Seach \& Match - ficha $77-0777^{1321}$ 


\subsection{Fabricação do combustível nuclear $\mathrm{UO}_{2}-\mathrm{Er}_{2} \mathrm{O}_{3}$}

Para a fabricação do combustível nuclear à base de $\mathrm{UO}_{2}$, é utilizado o procedimento de produtos fabricados pela metalurgia do pó.

Após a preparação e mistura (homogeneização) da matéria prima, o pó é levado à compactação em uma prensa, ganhando o formato de pastilhas que são direcionadas ao forno de sinterização, onde ganharão maior resistência mecânica e sofrerão um processo de redução do volume, devido à diminuição da sua porosidade. Após esse processo, as pastilhas são retificadas para garantir o formato cilíndrico, passam pelo

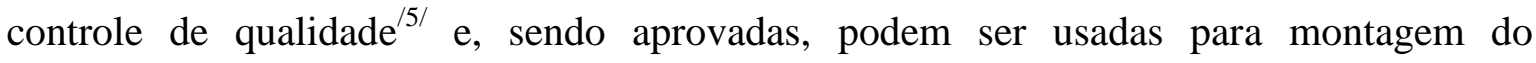
dispositivo que entrará no reator nuclear.

Em todo esse processo, a sinterização é o processo mais importante e pode ser definido como o processo técnico usado para produzir, com densidade controlada, materiais e componentes de pós metálicos ou cerâmicos pela aplicação de energia térmica $^{133 /}$.

O controle da porosidade é uma especificação importante para o controle da pastilha combustível, já que durante as fissões nucleares no caroço do reator nuclear os produtos de fissão são acomodados nos poros ${ }^{15 /}$.

Os mecanismos de transporte de material, que contribuem para o processo de densificação, têm como principal força motriz o excesso de energia de superfície entre os picos e vales $^{133 /}$, formados pela rugosidade das partículas e a união entre elas.

A literatura divide a sinterização em 3 estágios, conforme esquema mostrado na figura 3.

Na figura 3, os pós estão compactados (a) e com a sinterização se inicia a formação dos pescoços. No primeiro estágio (b), ocorre a formação dos pescoços, caracterizada pela união entre duas partículas. Na região do pescoço é criado um desequilíbrio na pressão de vapor, causando um transporte de massa e aumentando a formação do pescoço entre as partículas ${ }^{134 /}$. Além da formação do pescoço, há diminuição da rugosidade das partículas pelo mesmo princípio $^{1 / 35 /}$. Nessa etapa, a densificação é muito pequena, mas permite que outros mecanismos de transporte de material entrem em ação ${ }^{133 /}$. 
Figura 3: Transformação da microestrutura durante a sinterização

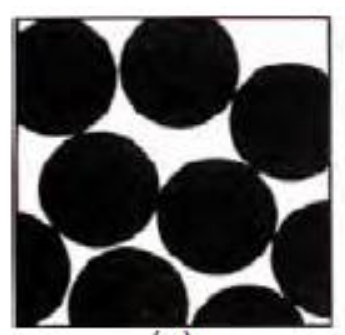

(a)

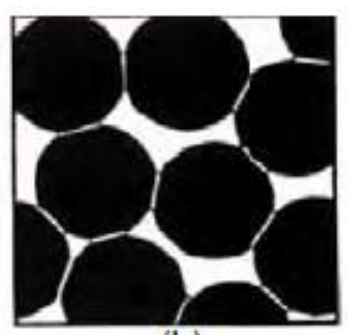

(b)

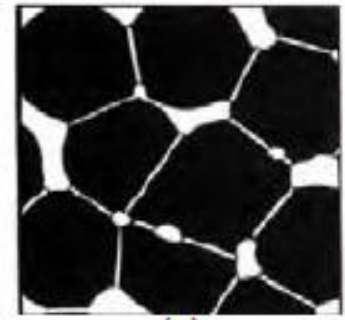

(c)

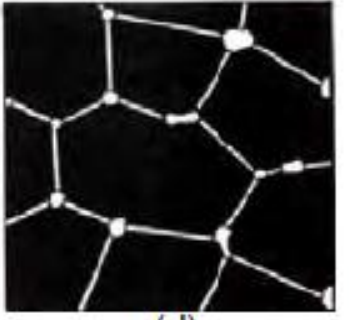

(d)

Fonte: Silva, $2010^{135 /}$

O estágio intermediário da sinterização (c) é caracterizado pela elevada densificação. Nesse estágio é possível o crescimento dos grãos e a estrutura interconectada começa a retrair, formando canais cilíndricos. A diminuição da porosidade e os mecanismos de transporte que diminuem a distância entre as partículas causam a densificação ${ }^{134 /}$.

O estágio final da sinterização (d) se caracteriza pela formação de poros isolados. Ou seja, os canais cilíndricos começam a se fechar, desconectando um poro do outro. Esse estágio é caracterizado por baixa retração ${ }^{1 / 3 /}$.

$\mathrm{O}$ processo de formação da solução sólida da mistura $\mathrm{UO}_{2}-\mathrm{Er}_{2} \mathrm{O}_{3}$ é caracterizado pela substituição de átomos de urânio por átomos de érbio, mantendo a estrutura cristalina do $\mathrm{UO}_{2}$. Esse processo é muito semelhante ao que ocorre ao sistema $\mathrm{UO}_{2}-\mathrm{Gd}_{2} \mathrm{O}_{3}$, onde é formada a solução sólida $(\mathrm{U}, \mathrm{Gd}) \mathrm{O}_{2}$. Essa solução sólida formada, principalmente nos casos entre o érbio e gadolínio, é substitucional, uma vez que os raios atômicos dos íons formados por esses elementos $\mathrm{Er}^{3+}$ e $\mathrm{Gd}^{3+}$ são muito próximos ao $\mathrm{U}^{4+}$, não permitindo que possam se acomodar nos interstícios da estrutura formada pelo $\mathrm{UO}_{2}$.

$\mathrm{O}$ raio atômico do $\mathrm{U}^{4+}$ e do $\mathrm{Er}^{3+}$ vale respectivamente $0,1001 \mathrm{~nm}$ e 0,1004 $\mathrm{nm}^{130 /}$. Essa semelhança favorece a troca entre os cátions, porém a valência é um fator que limita a substituição, já que a neutralidade elétrica precisa ser mantida.

Para se manter a neutralidade elétrica, a incorporação do cátion $\mathrm{Er}^{3+}$ precisa ser compensada pela oxidação do cátion $\mathrm{U}^{4+}$ para $\mathrm{U}^{5+}$ ou $\mathrm{U}^{6+}$ ou ocorrer a vacância de 
oxigênio, eliminando o íon $\mathrm{O}^{2-}$. A predominância de cada evento dependerá da atmosfera em que ocorrer a sinterização ${ }^{136 /}$.

Em atmosferas redutoras, os principais eventos defendidos na literatura são a oxidação do cátion $\mathrm{U}^{4+}$ para $\mathrm{U}^{5+}$ e a vacância de oxigênio. A somatória desses eventos contribui para diminuição do parâmetro de rede da estrutura fluorita, provavelmente pelo fato do raio atômico do $\mathrm{U}^{5+}$ ter o valor de $0,088 \mathrm{~nm}^{130 /}$, ou seja, menor que o $\mathrm{U}^{4+}$. Na figura 4 é mostrada a relação do parâmetro de rede com adição de átomos de érbio e gadolínio, em vários modelos matemáticos possíveis. Em todos os casos, há uma redução linear do parâmetro de rede, à medida que se adiciona o elemento de terra rara até a fração molar de $15 \%$.

Figura 4: Diminuição do parâmetro de rede da solução sólida (U,Gd)O $\mathrm{O}_{2}$ e (U,Er) $\mathrm{O}_{2}$

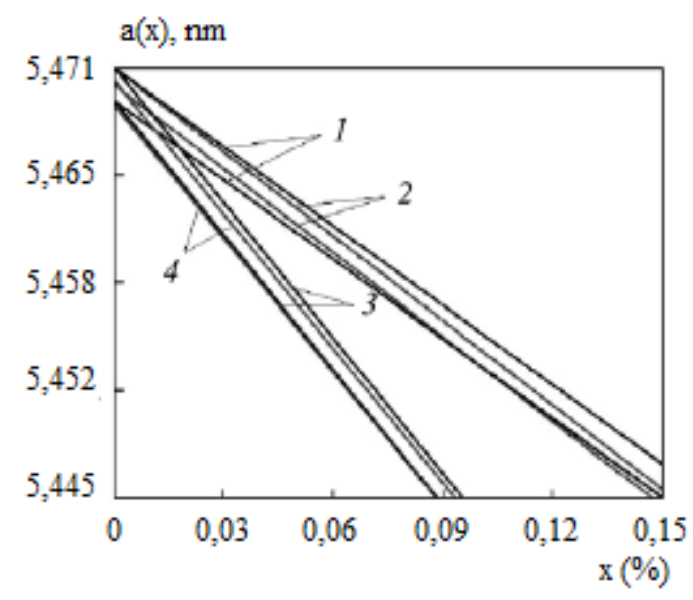

Fonte: Fedotov, A. V., et al, 2013

Na figura 4, as curvas 1 e 2 se referem à adição de gadolínio e as curvas 3 e 4 se referem à adição de érbio. Em cada caso, são usados modelos matemáticos diferentes, porém coerentes, e indicam a diminuição do parâmetro de rede com a adição dos cátions. A diferença do raio atômico dos cátions $\mathrm{Er}^{3+}$ e $\mathrm{Gd}^{3+}$ é o provável fator que faz com que a diminuição do parâmetro de rede ocorra de forma diferente, conforme visto na figura 4. 
Muitos autores confirmam a diminuição linear do parâmetro de rede da estrutura fluorita com o aumento da concentração de elementos pertencentes a terras raras. Esse é o comportamento que se observa quando há adição dos cátions $\mathrm{Er}^{3+} \mathrm{e} \mathrm{Gd}^{3+}$.

Considerando a concentração de elementos pertencentes a terras raras $(\mathrm{R})$ com $\mathrm{o}$ valor de $\mathrm{x}$ em fração molar na fórmula $\left(\mathrm{U}_{1-\mathrm{x}}, \mathrm{R}_{\mathrm{x}}\right) \mathrm{O}_{2}$, pode-se generalizar por meio da equação 3 o valor do parâmetro de rede, onde $\alpha_{0}$ e $\beta$ assumem posições de coeficiente linear e angular, respectivamente.

$$
\mathrm{a}(\mathrm{x})=\alpha_{0}-\beta x
$$

Onde,

$\mathrm{a}(\mathrm{x})$ : parâmetro de rede da solução sólida em função da concentração molar de R;

$\alpha_{0}$ : parâmetro de rede do $\mathrm{UO}_{2}$ puro

$\beta$ : coeficiente de diminuição do parâmetro de rede

$\mathrm{x}$ : fração molar de $\mathrm{R}$ presente na estrutura

A tabela 3 mostra alguns resultados dos coeficientes lineares e angulares apresentados na literatura, indicando que a solubilidade do érbio e gadolínio na estrutura fluorita do $\mathrm{UO}_{2}$ é completa até a faixa apresentada nesses estudos.

Os coeficientes angulares mais baixos referentes ao érbio indicam maior inclinação da curva, confirmando a figura 4, que mostra que o parâmetro de rede diminui mais com a adição do cátion $\mathrm{Er}^{3+}$ do que quando adicionado o $\mathrm{Gd}^{3+}$.

Os valores do parâmetro de rede, que deram origem às equações da tabela 3 , estão em função da concentração dos elementos de terras raras (Er e Gd) e dos raios atômicos $\mathrm{Er}^{3+}, \mathrm{U}^{4+}, \mathrm{U}^{5+}$ e $\mathrm{U}^{6+}$. Kim et al ${ }^{140 /}$ afirma que com a taxa de diminuição do parâmetro de rede de $-0,0264$ há preferência da oxidação do urânio para valência $5+$ em relação à valência $6+$ para a solução sólida $\left(\mathrm{U}_{1-\mathrm{x}}, \mathrm{Er}_{\mathrm{x}}\right) \mathrm{O}_{2}$. 
Tabela 3: Coeficientes da equação 3 para o érbio e o gadolínio

\begin{tabular}{lcccc}
\hline \multicolumn{1}{c}{ Cátion } & $\alpha_{0}$ & B & Faixa de estudo & Referência \\
\hline \multirow{2}{*}{ Érbio } & 0,5471 & 0,0264 & $0-0,20$ & Kim, S. H., et al $^{137 /}$ \\
& 0,54695 & 0,02704 & $0-0,10$ & Yamanaka, S., et al $^{/ 38 /}$ \\
Gadolínio & 0,54636 & 0,01592 & $0-0,50$ & Durazzo $^{/ 6 /}$ \\
& 0,54704 & 0,0174 & $0-0,15$ & Fukushima, S., et al $^{139 /}$ \\
\hline
\end{tabular}

A diminuição do parâmetro de rede e consequentemente do volume da célula unitária deve aumentar a densidade da solução sólida $(\mathrm{U}, \mathrm{R}) \mathrm{O}_{2}$. No entanto, uma vez que se trata de uma solução sólida substitucional, onde os cátions da terra rara (mais leves) substituem cátions de urânio, a massa de uma célula unitária diminui em comparação com o $\mathrm{UO}_{2}$. Tal diminuição de massa afeta a mudança de densidade mais que a diminuição do volume da célula unitária, fazendo com que a densidade da solução sólida (U,R) $\mathrm{O}_{2}$ diminua $^{130 /}$. Além de o érbio diminuir mais o parâmetro de rede, quando adicionado ao $\mathrm{UO}_{2}$, que o gadolínio, sua massa molar também é maior, fazendo com que a densidade da solução sólida seja maior, como pode ser observado na figura 5.

Na figura 5, as curvas 1 e 2 referem-se ao $\mathrm{Gd}_{2} \mathrm{O}_{3}$ e as curvas 3 e 4 referem-se ao $\mathrm{Er}_{2} \mathrm{O}_{3}$, que foram originadas de métodos computacionais e práticos, com resultados coerentes e indicam o decréscimo da densidade com a adição do veneno queimável em forma de óxido. Como nesse caso também existe uma dependência linear, pode-se estabelecer uma regressão linear para esses casos. Da mesma forma que a equação 3, também possui coeficiente angular negativo.

Os coeficientes angulares menores indicam uma maior inclinação da curva, confirmando a figura 5, onde a adição do $\mathrm{Gd}_{2} \mathrm{O}_{3}$ diminui mais a densidade teórica da solução sólida que a adição do $\mathrm{Er}_{2} \mathrm{O}_{3}$. 
Figura 5: Densidade teórica em função da fração mássica de $\mathrm{R}_{2} \mathrm{O}_{3}$

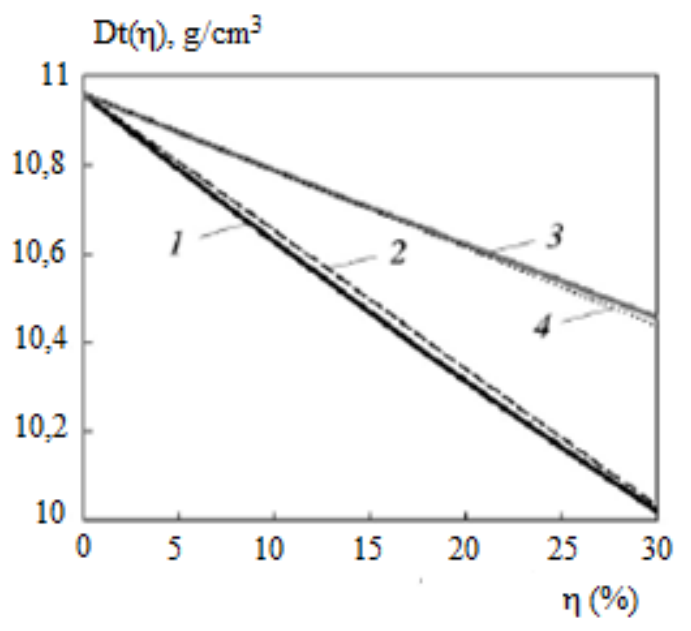

Fonte: Fedotov, A. V., et al, 2013

As equações que se ajustam ao gráfico apresentado na figura 5 são ${ }^{130 /}$ :

$$
\begin{gathered}
D t_{(U, E r) O_{2}}=10,96-0,0175 \eta \\
D t_{(U, G d) O_{2}}=10,96-0,031 \eta
\end{gathered}
$$

Onde,

$\eta$ : corresponde à fração mássica de $\mathrm{Er}_{2} \mathrm{O}_{3}$ ou $\mathrm{Gd}_{2} \mathrm{O}_{3}$

Para comparação, supondo acrescentar $10 \%$ em massa de óxido, teríamos uma densidade teórica de $10,79 \mathrm{~g} / \mathrm{cm}^{3}$ para o $\mathrm{Er}_{2} \mathrm{O}_{3}(98,4 \% \mathrm{Dt})$ e $10,65 \mathrm{~g} / \mathrm{cm}^{3}$ para $\mathrm{Gd}_{2} \mathrm{O}_{3}$ $(97,2 \% \mathrm{Dt})$.

Após a sinterização, a pastilha ainda passa pelo processo de retífica e inspeção. No processo de sinterização, ocorre uma retração desigual, deformando a pastilha, uma vez que há um gradiente de densidade no sentido da compactação. A retífica é importante para uniformizar a pastilha ao longo do seu diâmetro. Esse nivelamento é importante, pois quando a pastilha começar a queimar no caroço do reator, os produtos de fissão provocarão um inchamento e se suas extremidades tiverem um diâmetro maior que o centro, eles pressionam a haste que contem as pastilhas, provocando trincas. Os rejeitos gerados pela 
retífica e as pastilhas desaprovadas pela presença de trincas ou lascas são calcinadas a $\mathrm{U}_{3} \mathrm{O}_{8}$ e retornam ao processo de homogeneização da matéria prima ${ }^{15 /}$, sendo assim misturado ao $\mathrm{UO}_{2}$.

O combustível nuclear fabricado pela INB possui $12 \%$ de $\mathrm{U}_{3} \mathrm{O}_{8}$ na mistura ${ }^{126 /}$. Sua presença tem finalidade de garantir a porosidade, já que essa estrutura tem parâmetro de rede maior, deixando espaços vazios quando é reduzido a $\mathrm{UO}_{2}$ no processo de sinterização com atmosfera redutora.

A porosidade é importante no combustível nuclear para acomodação dos produtos de fissão, porém há outro fator que também auxilia nessa característica: o tamanho dos grãos, que também possui especificação determinada. A adição do $\operatorname{Er}_{2} \mathrm{O}_{3}$ na estrutura do $\mathrm{UO}_{2}$ diminui o tamanho de grão ${ }^{138 /}$, provavelmente pela criação de defeitos na rede, causando uma barreira para o seu crescimento.

Outra propriedade importante para o combustível nuclear é a condutividade térmica, que pode ser calculado de acordo com a equação 6 .

$$
\mathrm{K}=\alpha . \mathrm{C} . \rho
$$

Onde,

$\alpha$ : difusividade térmica

C: capacidade de calor específico

$\rho:$ densidade

Além da dependência da temperatura e da densidade, com o aumento do teor de $\mathrm{Er}_{2} \mathrm{O}_{3}$ na solução sólida (U,Er)O $\mathrm{O}_{2}$ a condutividade térmica diminui a baixas temperaturas. Em temperaturas próximas a $1200^{\circ} \mathrm{C}$ a condutividade térmica tem valores próximos com o aumento do teor de $\mathrm{Er}_{2} \mathrm{O}_{3}$. Esse caso ocorre quando a concentração molar de $\mathrm{Er}_{2} \mathrm{O}_{3}$ é de até $10 \%$, como também ocorre com o $\mathrm{Gd}_{2} \mathrm{O}_{3}$. Kim et al ${ }^{1 / 40 /}$ realizou os cálculos de condutividade térmica pelo método de flash laser, entre a temperatura 
ambiente e $1400^{\circ} \mathrm{C}$ e as pastilhas foram feitas com o $\mathrm{UO}_{2}$ e $\mathrm{Er}_{2} \mathrm{O}_{3}$ misturados a seco, com moinho de bolas e sinterizados a $1750^{\circ} \mathrm{C}$, com atmosfera de $\mathrm{H}_{2}$.

\subsection{Dilatometria}

A dilatometria é a técnica que permite a avaliação dimensional de uma amostra em função de um programa de temperatura controlada e uma atmosfera específica. $\mathrm{O}$ dilatômetro permite o aquecimento a uma taxa definida, enquanto é feito a leitura da alteração dimensional do objeto avaliado. Por meio dessa técnica, é possível avaliar a taxa de retração de um corpo cerâmico durante a sinterização, assim como possíveis mudanças de fase no estado sólido ${ }^{141 /}$.

A expansão ou retração do comprimento é um método mais eficaz que o acompanhamento da alteração volumétrica, uma vez que o primeiro pode ser medido com uma haste posicionada em cima da amostra. A mudança do comprimento da amostra é proporcional ao comprimento inicial, sendo usualmente dado pela razão $\left(1_{\mathrm{T}^{-}} \mathrm{l}_{0}\right) / 1_{0}$, onde $1_{\mathrm{T}}$ é o comprimento da amostra em dada temperatura $\mathrm{T}$ e $1_{0}$ é o comprimento inicial, medido à temperatura ambiente ${ }^{135 /}$.

A variação desse comprimento, também chamado de dilatação térmica, é proporcional à temperatura, ao comprimento inicial e também ao coeficiente de expansão térmica linear $(\alpha)$, que se trata de uma propriedade intrínseca de cada material. A equação 7 expressa a forma como essas grandezas se relacionam.

$$
\Delta \mathrm{l}=l_{0} \cdot \alpha \cdot \Delta \mathrm{T}
$$

Onde,

$\Delta \mathrm{l}$ : variação da dimensão linear

$1_{0}$ : comprimento inicial

$\Delta \mathrm{T}$ : variação da temperatura 


\section{MATERIAIS E MÉTODOS}

Neste capítulo apresenta-se a metodologia adotada para o desenvolvimento deste trabalho, que envolve as seguintes etapas:

- Caracterização das matérias primas dos pós de $\mathrm{UO}_{2}$ e $\mathrm{Er}_{2} \mathrm{O}_{3}$;

- Obtenção das pastilhas de $\mathrm{UO}_{2}-\mathrm{Er}_{2} \mathrm{O}_{3}$;

- Ensaios de sinterização das pastilhas por dilatometria;

- Caracterização das pastilhas sinterizadas.

Na Figura 6, é mostrado as principais atividades envolvidas no procedimento experimental adotado neste estudo.

Figura 6: Diagrama de blocos do procedimento adotado

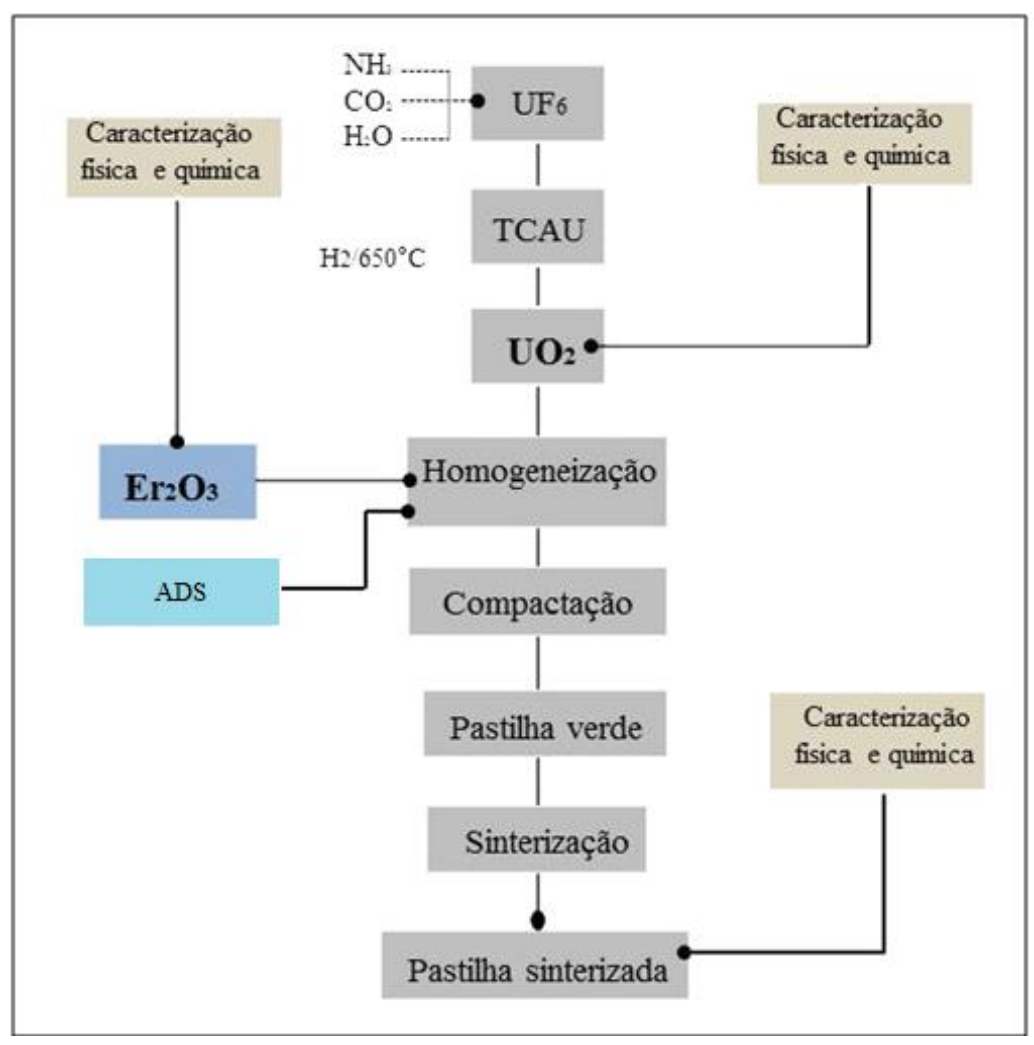

Fonte: Autor da dissertação 
Neste estudo foram produzidas pastilhas de $\mathrm{UO}_{2}$ e $\mathrm{UO}_{2}-\mathrm{Er}_{2} \mathrm{O}_{3}$ com concentração de $1,0 \%, 2,5 \%, 4,0 \%$ e 9,8\%. Esta concentração foi escolhida de acordo com as concentrações utilizadas comercialmente e propostas realizadas na literatura ${ }^{14,16 /}$, com vista a aumentar o tempo de vida do combustível nuclear.

\subsection{Materiais utilizados}

$\mathrm{O}$ pó de $\mathrm{UO}_{2}$ utilizado nesse estudo foi fornecido pelas Indústrias Nucleares do Brasil - INB, sendo fabricado pela redução direta do tricarbonato de amônio e uranilo $\mathrm{TCAU}^{26 /}$. Obtém-se o TCAU a partir do hexafluoreto de urânio - $\mathrm{UF}_{6}$, segundo a reação química $1^{/ 9 /}$.

$$
\mathrm{UF}_{6}+5 \mathrm{H}_{2} \mathrm{O}+10 \mathrm{NH}_{3}+3 \mathrm{CO}_{2} \longrightarrow\left(\mathrm{NH}_{4}\right)_{4} \mathrm{UO}_{2}\left(\mathrm{CO}_{3}\right)_{3}+6 \mathrm{NH}_{4} \mathrm{~F}
$$

Para obtenção do pó de $\mathrm{UO}_{2}$, o TCAU foi reduzido em forno de leito fluidizado, com atmosfera composta pela mistura de $\mathrm{H}_{2}$ e vapor superaquecido, segundo a reação química $2^{/ 42 /}$.

$$
\left(\mathrm{NH}_{4}\right)_{4} \mathrm{UO}_{2}\left(\mathrm{CO}_{3}\right)_{3}+\mathrm{H}_{2} \longrightarrow \mathrm{UO}_{2}+3 \mathrm{CO}_{2}+3 \mathrm{H}_{2} \mathrm{O}+4 \mathrm{NH}_{3}
$$

O pó de óxido de érbio utilizados nesse trabalho foi adquirido no mercado internacional, com 99,9\% de pureza, marca Alfa Aesar.

Para auxílio na compactação das pastilhas de $\mathrm{UO}_{2}$ e $\mathrm{UO}_{2}-\mathrm{Er}_{2} \mathrm{O}_{3}$, foram utilizados o lubrificante sólido diestearato de alumínio $\left(\mathrm{C}_{36} \mathrm{H}_{71} \mathrm{O}_{5} \mathrm{Al}\right)$ - ADS, também fornecido pela INB, e estearato de zinco $\left(\mathrm{C}_{36} \mathrm{H}_{70} \mathrm{O}_{4} \mathrm{Zn}\right)$, marca Quimesp. 


\subsection{Caracterização química e física}

Antes da fabricação das pastilhas, fez-se uma caracterização química e física dos materiais utilizados no estudo $\left(\mathrm{UO}_{2}\right.$ e $\left.\mathrm{Er}_{2} \mathrm{O}_{3}\right)$ visando o máximo controle do processo, utilizando as infraestruturas existentes no IPEN-CNEN-SP e na INB. Segundo a literatura consultada os materiais utilizados como combustíveis nucleares devem ter suas características e propriedades extremamente definidas garantindo o desempenho sob irradiação, sob o ponto de vista de rendimento e de segurança ${ }^{15 /}$.

Para a caracterização desses compostos utilizou-se as seguintes técnicas:

- Traços de impurezas

Técnica: espectroscopia de emissão óptica por plasma acoplado indutivamente e cromatografia iônica.

As impurezas medidas foram identificadas por espectroscopia de emissão óptica por plasma acoplado indutivamente, modelo Optima 2100 DV, marca Perkin Elmer. Sendo identificado o teor de alumínio, cálcio, boro, ferro, níquel, silício e gadolínio. A técnica consiste em excitar os átomos que emitem radiação, com comprimento de onda característico, podendo assim ser identificado.

O teor de flúor foi identificado por cromatografia iônica, modelo 850 IC Professional, marca Metrohm. A técnica consiste na separação de íons que é obtida quando os componentes da amostra são carregados pela fase móvel, ou efluentes. Os íons migram e interagem com a fase estacionária. A separação resulta de diferentes velocidades de migração como consequência do equilíbrio da distribuição, gerando sinais de condutividade.

- Relação O/U e urânio total

Técnica: Termogravimetria.

Realizada por termogravimentria (TG), a técnica consiste na oxidação do pó de $\mathrm{UO}_{2}$ até a formação da fase $\mathrm{U}_{3} \mathrm{O}_{8}$, realizada em forno mufla AN1222-W64 e balança analítica AB204, marca Metller Toledo. 
Durante a TG, ocorre um primeiro estágio de oxidação, onde ocorre a transformação do $\mathrm{UO}_{2}$ (cúbico) para $\mathrm{U}_{3} \mathrm{O}_{7}$ (tetragonal). Essa estrutura permanece entre as temperaturas de $280^{\circ} \mathrm{C}$ e $330^{\circ} \mathrm{C}$. Com o aumento da temperatura, ocorre um segundo estágio de oxidação onde é formado o $\mathrm{U}_{3} \mathrm{O}_{8}$ (ortorrômbico) ${ }^{142 /}$. Com a alteração da massa, é possível calcular a fração molar de urânio e oxigênio original no pó e assim determinar a relação $\mathrm{O} / \mathrm{U}$ e a porcentagem de urânio presente na amostra, como demonstrado na equação $8^{/ 28 /}$.

$$
\frac{O}{U}=\frac{m_{i}}{m_{f}} \cdot\left(15,8750-\frac{9 P}{48}\right)-\left(14,8750-\frac{3 P}{16}\right)
$$

Onde,

$\mathrm{m}_{\mathrm{i}}$ : massa inicial

$\mathrm{m}_{\mathrm{f}}$ : massa final

P: porcentagem em massa do isótopo ${ }^{235} \mathrm{U}$

- $\quad$ Área de superfície específica

Técnica: Brunauer, Emmett e Teller (BET)

É calculada pela determinação do peso do vapor adsorvido em função da pressão de vapor a temperatura constante. A equação de BET modelou o equilíbrio entre o vapor e o adsorvente, chegando ao valor da área de superfície específica.

Ensaio realizado com analisador de superfície específica, modelo HM 1208, modelo Macsorb.

- Escoabilidade e Densidade aparente

Técnica: Funil, peso e tempo

A determinação da escoabilidade se baseia em verificar o tempo que $50 \mathrm{~g}$ de pó escoam em um funil metálico, com orifício de 1,5 mm de diâmetro. Esse mesmo pó é coletado em um recipiente metálico, com volume útil de $25 \mathrm{~mL}$. A razão entre a massa de pó e seu volume determina a densidade aparente ou densidade solta. 
- Identificação de fase

Técnica: Difratometria de raios $\mathrm{X}$

Os difratogramas foram obtidos no difratômetro de raios $\mathrm{X}$, marca Bruker, modelo D8 Advance, de geometria Bragg-Bretano, com fendas soller de 2,5 , fendas antiespalhamento e divergente de $1 \mathrm{~mm}$ e fenda de recepção de $0,4 \mathrm{~mm}$, utilizando o tubo de radiação $\mathrm{Cu}-\mathrm{K} \alpha$ colimado e monocromado $(\lambda=1,54 \AA$ ). A intensidade espalhada foi medida do ângulo $2 \Theta$ igual a $10^{\circ}$ até $90^{\circ}$ e com 10 segundos por passo de $0,02^{\circ}$. O refinamento dos resultados da difração de raios X pelo método de Rietveld foi realizado com o programa Topas versão 4.2 (Bruker).

Os raios $\mathrm{X}$ são radiações eletromagnéticas, da mesma natureza que a luz, porém, com comprimento de onda muito menor. Quando um feixe de raios X incide sobre um material sólido cristalino, uma parte se dispersa ou se espalha ${ }^{143 /}$. Quando a condição da lei de Bragg é obedecida, há uma contagem em ângulo característico, formando os picos característicos ao material em ângulo $2 \Theta$ determinado.

- Análise de distribuição de tamanho de partícula por difração a laser

Técnica: Difração a laser

A distribuição de tamanho de partícula foi feita utilizando a técnica de laser obtida no granulômetro marca Cilas, modelo 1064 liquid. Esta técnica se baseia no princípio que o ângulo de difração é inversamente proporcional ao tamanho de partícula, que foram dispersas por ultrassom em meio líquido. A luz proveniente de um laser, com comprimento de onda de $830 \mathrm{~nm}$, é descontinuada pelas partículas em suspensão, resultando na difração do feixe.

\section{- Morfologia}

Técnica: Microscopia eletrônica de varredura (MEV)

A morfologia foi analisada por meio de um microscópio eletrônico de varredura (MEV), marca Jeol, modelo JSM 60102A. Consiste em imagem gerada por elétrons, emitidos por efeito termiônico, gerados por um filamento aquecido de tungstênio. 
O filamento atua como cátodo e a abertura como ânodo, por onde os elétrons acelerados atravessam. Os elétrons são acelerados pela alta tensão aplicada e pela ação do campo elétrico.

Existe um conjunto de características prioritárias do pó de $\mathrm{UO}_{2}$ para a sinterização, sejam pela importância "a posteriori", como também durante o processo de fabricação. São elas: relação $\mathrm{O} / \mathrm{U}$, superfície específica, tamanho médio de partículas, reatividade química e microscopia. As características do pó são importantes para a sinterização, na medida em que elas influem no processo. Dentre elas podemos ressaltar: relação $\mathrm{O} / \mathrm{U}$, superfície específica e tamanho de partícula $^{/ 9 /}$.

\subsection{Obtenção das Pastilhas (U,Er) $\mathrm{O}_{2}$}

\subsubsection{Mistura mecânica de pós}

A mistura de pós é a etapa da fabricação que define o grau de homogeneidade da mistura, que pode ocorrer a nível molecular, como o processo de coprecipitação e solgel, ou como pós finos, pela via seca.

A melhora na mistura da homogeneidade é um item importante no processo, sendo estudado por diversos pesquisadores. Quanto mais homogênea é a mistura, melhor ocorre a difusão entre os aglomerados dos pós que estão misturados e mais uniformes serão suas propriedades ao longo da pastilha, tanto do ponto de vista metalúrgico, durante a sinterização, como do ponto de vista neutrônico.

Uma opção existente na literatura da homogeneização pela via seca é a comoagem da mistura. A técnica é utilizada para que os aglomerados sejam quebrados e ocorra uma melhor densificação da pastilha ${ }^{25 /}$.

Nesse estudo é utilizado a via seca, porém por meio da mistura mecânica. Apesar desse processo possibilitar a ocorrência de segregação de partículas, principalmente pela diferença de peso entre as partículas, é o processo mais simples e mais utilizado ${ }^{19 /}$.

Para a preparação da matéria prima, inicialmente foi realizado a pesagem dos materiais, nas porcentagens necessárias para cada pastilha, levando em consideração as diferentes concentrações de óxido de érbio utilizadas nesse trabalho. As porções de $\mathrm{Er}_{2} \mathrm{O}_{3}$, $\mathrm{UO}_{2}$ e ADS foram retiradas em diferentes posições do frasco, para garantir a 
representatividade da amostra. Em todas as pastilhas, a concentração de ADS foi de 0,2\%, seguindo o padrão da $\mathrm{INB}^{26 /}$. O material foi pesado em balança analítica, marca Shimadzu, com precisão de $0,0001 \mathrm{~g}$.

Neste estudo não foi utilizado a técnica de mistura matriz, normalmente utilizada $^{/ 24 /}$, com vista a melhorar a homogeneidade evitando, mesmo após a sinterização, a presença de $\mathrm{UO}_{2}$ e $\mathrm{Er}_{2} \mathrm{O}_{3}$ livre na pastilha. Porém, com a expectativa de melhorar a homogeneidade, após a pesagem, o material foi colocado em um dispositivo, que se baseia em um recipiente de polietileno com capacidade de $100 \mathrm{~cm}^{3}$, com fios trançados no seu interior, favorecendo a quebra de aglomerados para melhorar a mistura dos pós. Após o fechamento do recipiente, este foi posicionado no homogeneizador tipo túrbula, marca WabTurbula, modelo T2F, com uma rotação de $48 \mathrm{rpm}$ durante 1 hora. Após esse período, não era mais possível visualizar aglomerados de $\mathrm{Er}_{2} \mathrm{O}_{3}$, nem do ADS.

\subsubsection{Compactação das pastilhas}

A técnica de compactação tem por princípio a aplicação de pressão em pós, transformando-os em sólidos com a geometria do seu ferramental. A vantagem dessa técnica é a repetibilidade dimensional e o controle de densidade, que é dependente da pressão aplicada.

Nesse trabalho foi utilizada a compactação uniaxial com matriz flutuante, onde é utilizado um ferramental com 3 componentes: matriz, punção superior e punção inferior.

A compactação simples, ou uniaxial, é melhor usada onde a relação altura $\mathrm{x}$ diâmetro (H/D) for pequena ${ }^{/ 44 /}$. Neste estudo, a relação H/D foi mantida entre 1,0 e 1,1, mesmo assim ocorre um gradiente de densidade entre o topo da pastilha e o centro. Isto se deve ao atrito entre as partículas e entre as partículas e a parede da matriz, fazendo com que a pressão exercida pelos punções não se distribua uniformemente ao longo da pastilha. Os lubrificantes utilizados para compactação das pastilhas têm o objetivo de diminuir esse atrito, sendo utilizado o ADS misturado junto ao pó e o estearato de zinco nas paredes da matriz e punções.

As pastilhas compactadas são usualmente denominadas "pastilhas verdes". A compactação foi realizada com uma prensa hidráulica, marca Ribeiro, modelo P15T e a 
força de compactação, exercida pela prensa, foi estabelecida entre 3,0 e 3,6 tf/ $\mathrm{cm}^{2}$, dependendo da concentração de óxido de érbio utilizado, de modo que a pastilha fabricada tenha uma densidade geométrica entre $5,39 \mathrm{~g} / \mathrm{cm}^{3}$ e $5,55 \mathrm{~g} / \mathrm{cm}^{3}(50,50 \% \pm 0,50 \mathrm{da}$ densidade teórica da mistura $\mathrm{UO}_{2}-\mathrm{Er}_{2} \mathrm{O}_{3}-\mathrm{ADS}$ ). A massa de pó misto carregada na matriz foi anteriormente calculada para que fossem obtidas pastilhas com altura aproximada de 11 $\mathrm{mm}$.

Inicialmente, a matriz e os punções são lubrificados com uma mistura de acetona e estearato de zinco para diminuir o atrito do pó com as paredes da matriz. Por método empírico, esse procedimento facilita a extração da peça da matriz, além de diminuir os efeitos referentes à distribuição de pressão ao longo da parede da matriz.

Após a lubrificação, o material já misturado é adicionado com a massa correta dentro da matriz, com o punção inferior posicionado para reter o pó na cavidade da matriz. Só então, o punção superior é inserido e se dá o início à compactação.

Para extração da peça, é retirado o punção superior e utilizado um dispositivo que empurra a matriz para baixo, porém com espaço para a pastilha sair. Foi adicionado um dispositivo de contra pressão, para que a pastilha receba uma tensão de compactação durante a extração. Verificou-se que esse dispositivo diminui a probabilidade de trinca. A figura 7 mostra a montagem do dispositivo.

Para obtenção das medidas dimensionais da pastilha foi utilizado um paquímetro, marca Mitutoyo, com precisão de 0,01mm. Em todas as pastilhas feitas, o diâmetro encontrado foi de $10,34 \mathrm{~mm}$, dimensão maior que o ferramental. Essa variação é chamada "spring-back" e é referente à expansão do compactado após a extração da ferramenta ${ }^{144 /}$.

A densidade é um dos principais parâmetros de qualquer produto feito por metalurgia do pó. No caso do combustível nuclear, a importância é significativa, pois sua variação traz grande impacto na pastilha produzida ${ }^{28 /}$. 
Figura 7: Dispositivo para extração da peça do ferramental de compactação
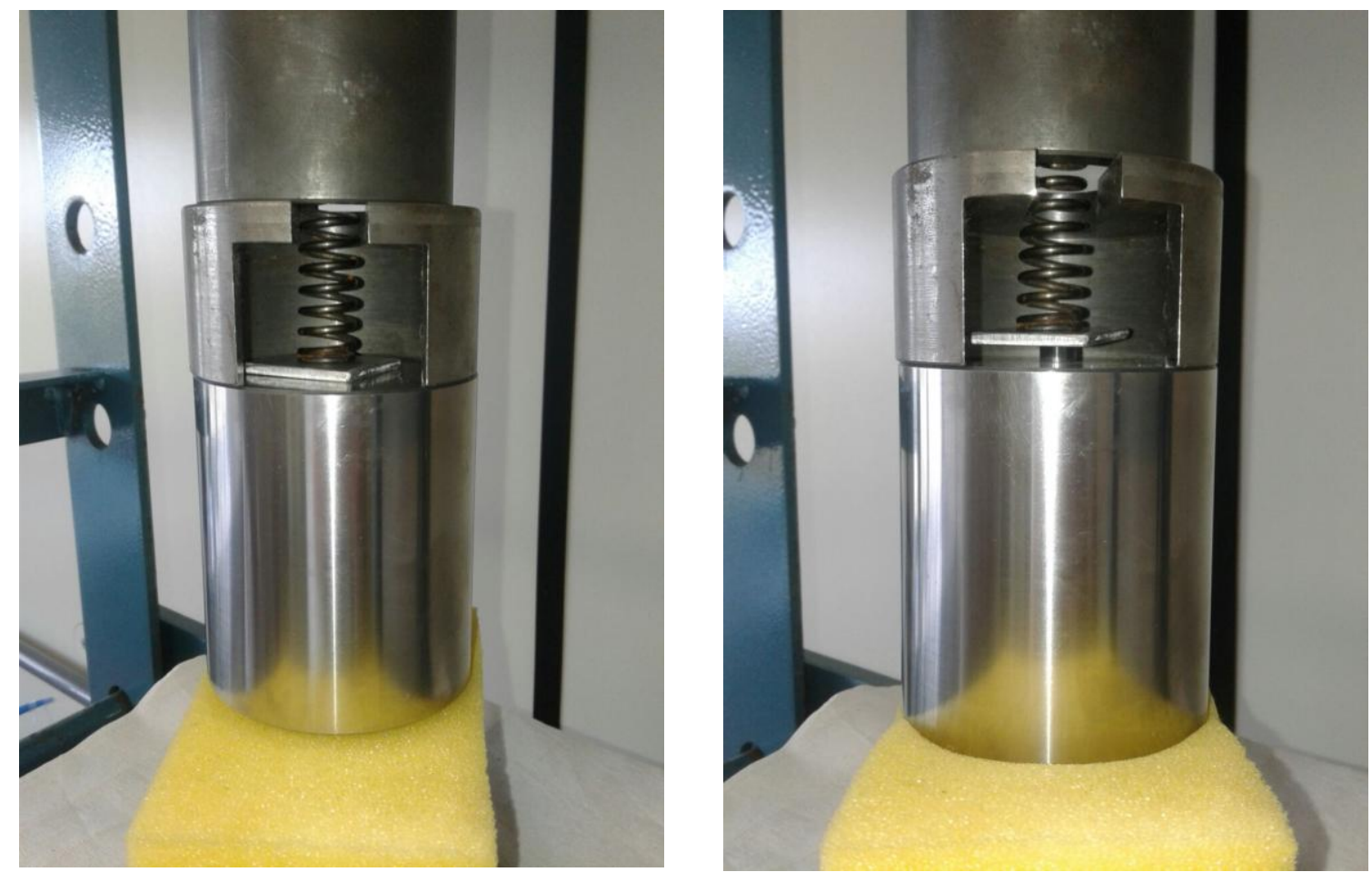

Fonte: autor da dissertação

$\mathrm{Na}$ mistura de pó, a densidade teórica se modifica com a adição dos componentes. A densidade por definição é a razão entre a massa e o volume e a densidade da mistura pode ser calculada de acordo com a equação 9.

$$
d=\frac{100}{\left(\frac{x}{10,96}+\frac{y}{8,64}+\frac{\mathrm{z}}{5,35}\right)}
$$

Onde,

x: fração mássica de $\mathrm{UO}_{2}$

y: fração mássica de $\mathrm{Er}_{2} \mathrm{O}_{3}$

z: fração mássica de ADS 
$\mathrm{Na}$ equação, os valores de $10,96 \mathrm{~g} / \mathrm{cm}^{3}, 8,64 \mathrm{~g} / \mathrm{cm}^{3}$ e $5,35 \mathrm{~g} / \mathrm{cm}^{3} / 45 /$ correspondem respectivamente à densidade teórica do $\mathrm{UO}_{2}, \mathrm{Er}_{2} \mathrm{O}_{3}$ e $\mathrm{ADS}$.

\subsubsection{Sinterização}

A sinterização é aplicada em peças sólidas, em temperaturas próximas a dois terços do ponto de fusão do material (temperatura absoluta), em fornos capazes de operar com tempos e temperaturas elevadas, além do controle de atmosfera, podendo elevar a densidade e resistência mecânica ${ }^{19 /}$, por meio do incremento da coesão entre as partículas.

A sinterização pode ser dividida em dois tipos: sinterização por fase sólida, onde todos os materiais se matêm no estado sólido com o aumento da temperatura, e a sinterização com fase líquida, quando um dos componente muda de estado sólido para líquido durante a sinterização. A temperatura de fusão do $\mathrm{UO}_{2}$ é $2850^{\circ} \mathrm{C} \pm 20^{\circ} \mathrm{C}$ e vai diminuindo com o aumento da concentração de $\mathrm{Er}_{2} \mathrm{O}_{3}{ }^{1 / 6 /}$. A temperatura de fusão do $\mathrm{Er}_{2} \mathrm{O}_{3}$ é $2355^{\circ} \mathrm{C}^{113 /}$, portanto a temperatura de sinterização utilizada de $1700^{\circ} \mathrm{C}$ não é suficiente para transformação de estado sólido-líquido de nenhum dos componentes utilizados nesse estudo.

Nesse estudo, as sinterizações foram feitas com o dilatômetro, marca Setaram, modelo Setsys, representado na figura 8. O dilatômetro vertical tem a vantagem de não ocupar muito espaço, comparando com os modelos horizontais e podendo ser usado a própria gravidade para manter o contato da haste com a amostra ${ }^{/ 41 /}$.

O equipamento de análise térmica dilatômetro é constituído por um forno, um termopar, uma haste, um sistema de fluxo de gás e um LVDT (linear variable differencial transformer) que é um transdutor que consegue ler a posição da haste, e sua variação ao longo do ciclo térmico estabelecido, transformando um sinal elétrico em uma medida física $^{135,41 /}$. Os materiais envolvidos nesse processo precisam ter baixo coeficiente de expansão térmica, para evitar interferências na análise e alto ponto de fusão ${ }^{19 /}$, já que o equipamento precisa funcionar a altas temperaturas. $\mathrm{O}$ conjunto utilizado nos ensaios é composto de haste, base e tubo carregador de alumina resinterizada. Um disco de alumina resinterizada é colocado entre a amostra e a haste visando o alinhamento. 
Figura 8: Dilatômetro vertical utilizado para sinterização.

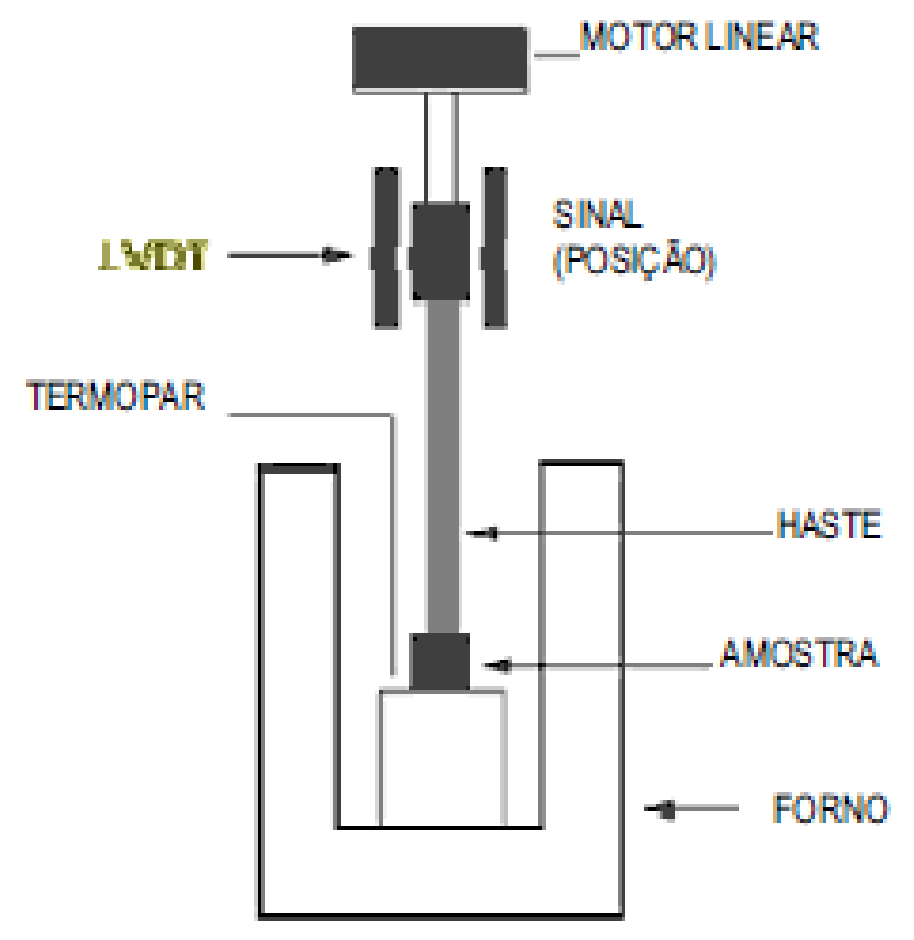

Fonte: Silva, 2010.

A variação na dimensão da amostra provoca o deslocamento da haste, que está em contato com a amostra aplicando uma pequena pressão, sendo seu deslocamento detectado pelo LVDT, que irá converter essa mudança em uma diferença de potencial possibilitando alterações dimensionais de $0,1 \mu \mathrm{m}$. A função da haste conectada ao LVDT é pressionar a mostra contra uma base, fazendo com que qualquer alteração dimensional seja acompanhada pelo sensor.

Antes das amostras serem colocadas no dilatômetro, são feitas medidas geométricas e pesagem para determinação da densidade a verde. Ao término dos ensaios o procedimento foi repetido para a verificação da densidade geométrica sinterizada. $\mathrm{Na}$ sequência, a densidade final é obtida pelo método de Arquimedes.

A atmosfera utilizada no forno foi $\mathrm{H}_{2}$ de alta pureza (mínimo de 99,995\%, com teor de $\mathrm{H}_{2} \mathrm{O}$ menor que $10 \mu \mathrm{g} / \mathrm{gH}_{2}$ e teor de $\mathrm{O}_{2}$ menor que $5 \mu \mathrm{g} / \mathrm{gH}_{2}$ ), com fluxo de 3 litros/hora. 
$\mathrm{O}$ aquecimento ocorreu a uma taxa de $5^{\circ} \mathrm{C}$ por minuto, até a temperatura de $1700^{\circ} \mathrm{C}$, na qual permanece por 180 minutos e depois inicia o resfriamento com taxa de $20^{\circ} \mathrm{C}$ por minuto, até a temperatura de $300^{\circ} \mathrm{C}$, onde o equipamento foi desligado, seguindo o resfriamento de modo natural até a temperatura ambiente.

A dilatometria fornece indícios sobre a temperatura de solubilização do érbio na estrutura cristalina do $\mathrm{UO}_{2}$, porém essa informação é confirmada pela análise térmica diferencial (ATD).

A análise térmica diferencial foi realizada no mesmo equipamento do dilatômetro, com mudança dos instrumentos que permite medir o fluxo de calor relacionado a transformações químicas e/ou físicas que ocorrem no material em função do tratamento térmico a que o mesmo é submetido (temperatura e tempo) em uma atmosfera controlada.

Foi utilizado o mesmo programa de aquecimento e atmosfera redutora de $\mathrm{H}_{2}$ utilizado na dilatometria. A análise foi realizada com fragmentos de pastilha verde com 9,8\% de concentração de $\mathrm{Er}_{2} \mathrm{O}_{3}$ (concentração mais alta presente nesse estudo) e adicionado em um porta-amostra inserido no equipamento. Essa concentração foi preferida nessa análise, pois a alta fração mássica de érbio proporciona maior quantidade de reação. O fragmento da pastilha compactada foi escolhido para ser analisado, pois é oriundo da pastilha compactada e assim existe maior contato, do que a mistura solta dos pós.

A ATD compreende medir a diferença de temperatura de uma amostra e de uma referência, que estão expostas a um mesmo cronograma de aquecimento ${ }^{141 /}$. A análise permite identificar mudanças físicas e químicas que envolvem processos endotérmicos ou exotérmicos, ou mudanças na capacidade de calor específico. A diferença entre a temperatura da amostra e a referência é medida em microvolts $(\mu \mathrm{V})$ por um termopar diferencial em que a junção está em contato com a parte inferior do cadinho.

\subsubsection{Densidade da pastilha sinterizada}

Quando a pastilha é sinterizada, ocorrem deformações na pastilha. A medição do volume, necessária para chegar ao valor da densidade, acarretaria em erros decorrentes 
da variação de diâmetro ao longo do comprimento da pastilha e por isso será utilizado o método de imersão em água, descrito na norma ASTM C373-88 ${ }^{/ 47 /}$, também conhecido como método de Arquimedes para o cálculo da densidade. Nesse método, o volume pode ser calculado segundo a equação 10 .

$$
\mathrm{V}=\frac{\mathrm{m}_{\mathrm{u}}-\mathrm{m}_{\mathrm{i}}}{\rho_{\text {água }}}
$$

Onde,

$\mathrm{m}_{\mathrm{u}}$ : massa úmida

$\mathrm{m}_{\mathrm{i}}$ : massa imersa

$\rho_{\text {água }}:$ densidade da água

O procedimento descrito na norma para medição da densidade do corpo sinterizado consiste na fervura da pastilha por 5 horas e descanso por 5 horas, para medição da massa imersa e úmida. A fervura da pastilha em água é importante para que as moléculas de água diminuam sua tensão superficial e penetrem nos poros abertos da pastilha. No entanto, estudos indicam que a fervura da pastilha por 1 hora e suprimindo o tempo de repouso não afeta de forma significativa o valor do volume da pastilha ${ }^{/ 48 /}$. Neste estudo, esse procedimento foi usado para evitar oxidação da pastilha. As massas foram medidas em balança analítica, marca Mettler Toledo, com precisão de 0,01 mg. 


\section{RESULTADOS E DISCUSSÕES}

\subsection{Caracterização físico química}

As matérias primas utilizadas neste trabalho foram caracterizadas química e fisicamente. As tabelas 4 e 5, apresentam-se os resultados obtidos do pó de $\mathrm{UO}_{2}$ e $\mathrm{Er}_{2} \mathrm{O}_{3}$.

Tabela 4: Características químicas e físicas do pó de $\mathrm{UO}_{2}$ proveniente do TCAU

\begin{tabular}{|c|c|c|c|c|c|c|c|c|}
\hline \multicolumn{3}{|c|}{ Análise } & \multicolumn{3}{|c|}{ Valor } & \multicolumn{3}{|c|}{ Especificação } \\
\hline \multicolumn{3}{|l|}{$\mathrm{O} / \mathrm{U}$} & \multicolumn{3}{|c|}{2,0818} & \multicolumn{3}{|c|}{$2,08-2,30$} \\
\hline \multicolumn{3}{|l|}{$\mathrm{U}_{\text {total }}(\%)$} & \multicolumn{3}{|c|}{87,574} & \multicolumn{3}{|c|}{$\geq 86,8$} \\
\hline \multicolumn{3}{|c|}{ Enriquecimento em peso de ${ }^{235} \mathrm{U}(\%)$} & \multicolumn{3}{|c|}{4,137} & \multicolumn{3}{|c|}{$4,10-4,15$} \\
\hline \multicolumn{3}{|c|}{ Umidade (\% de massa) } & \multicolumn{3}{|c|}{0,15} & \multicolumn{3}{|c|}{$\leq 0,4$} \\
\hline \multicolumn{3}{|c|}{ Área de superfície específica $\left(\mathrm{m}^{2} / \mathrm{g}\right)$} & \multicolumn{3}{|c|}{5,0} & \multicolumn{3}{|c|}{$2,5-6,0$} \\
\hline \multicolumn{3}{|c|}{ Densidade aparente $\left(\mathrm{g} / \mathrm{cm}^{3}\right)$} & \multicolumn{3}{|c|}{2,2} & \multicolumn{3}{|c|}{$2,0-2,6$} \\
\hline \multicolumn{3}{|c|}{ Escoabilidade $(\mathrm{s} / 50 \mathrm{~g})$} & \multicolumn{3}{|c|}{4,6} & \multicolumn{3}{|c|}{$\leq 10$} \\
\hline \multicolumn{3}{|l|}{$\mathrm{D} 50(\mu \mathrm{m})$} & \multicolumn{3}{|c|}{30,04} & \multicolumn{3}{|c|}{$<200$} \\
\hline \multicolumn{9}{|c|}{ Traços de impureza $(\mu \mathrm{g} / \mathrm{gU})$} \\
\hline Impurezas & $\mathrm{F}$ & $\mathrm{Al}$ & $\mathrm{Ca}$ & $\mathrm{B}$ & $\mathrm{Fe}$ & $\mathrm{Ni}$ & $\mathrm{Si}$ & $\mathrm{Gd}$ \\
\hline $\mathrm{UO}_{2}$ & 5,312 & 1,777 & 4,212 & $<0,2$ & 15,24 & 0,421 & 6,916 & 0,2 \\
\hline Especificação & $\leq 100$ & $\leq 250$ & $\leq 25$ & $\leq 0.5$ & $\leq 100$ & $\leq 50$ & $\leq 100$ & $\leq 1$ \\
\hline
\end{tabular}

Fonte: Análise enviada pela INB 
Tabela 5: Características químicas e físicas do pó de $\mathrm{Er}_{2} \mathrm{O}_{3}$

\begin{tabular}{|c|c|c|c|c|c|c|c|c|}
\hline \multicolumn{4}{|c|}{ Parâmetro } & \multicolumn{5}{|c|}{ Valor } \\
\hline \multicolumn{4}{|c|}{ Densidade teórica $\left(\mathrm{g} / \mathrm{cm}^{3}\right)$} & \multicolumn{5}{|c|}{8,64} \\
\hline $\mathrm{D} 50(\mu \mathrm{m})$ & & & & \multicolumn{5}{|c|}{11,10} \\
\hline Umidade $(9$ & & & & \multicolumn{5}{|c|}{0,25} \\
\hline \multicolumn{9}{|c|}{ Traços de impureza $\left(\% \mathrm{Er}_{2} \mathrm{O}_{3}\right)$} \\
\hline Impurezas & $\mathrm{Dy}_{2} \mathrm{O}_{3}$ & $\mathrm{Ho}_{2} \mathrm{O}_{3}$ & $\mathrm{Tm}_{2} \mathrm{O}_{3}$ & $\mathrm{Yb}_{2} \mathrm{O}_{3}$ & $\mathrm{Y}_{2} \mathrm{O}_{3}$ & $\mathrm{Fe}_{2} \mathrm{O}_{3}$ & $\mathrm{SiO}_{2}$ & $\mathrm{CaO}$ \\
\hline Er2O3 & 5,312 & 1,777 & 4,212 & $<0,2$ & 15,24 & 0,421 & 6,916 & 0,2 \\
\hline
\end{tabular}

Fonte: Autor da dissertação

Tanto a caracterização química quanto a caracterização física fornecem informações que caracterizam a qualidade do combustível nuclear, tais como a concentração de impurezas metálicas, o teor de urânio e relação O/U.

Como apresentado na tabela 4, os contaminantes estão dentro da especificação utilizada pela INB, podendo ser usado para confecção de pastilhas sem alteração das propriedades químicas devido à baixa presença de outros elementos químicos. A presença de impurezas pode acarretar uma formação de fases que podem levar a alterações no combustível. Como exemplo pode-se citar a presença de elementos com alta secção de choque de absorção de nêutrons que podem comprometer o combustível, assim pode-se estabelecer que não há nenhum aspecto químico que inviabilize o material.

A relação $\mathrm{O} / \mathrm{U}$, urânio total, grau de enriquecimento e umidade também ficaram dentro do parâmetro estabelecido pela INB. A condutividade térmica, a resistência mecânica, fluência e outras propriedades podem ser alteradas se a relação O/U estiver fora da faixa determinada.

As análises físicas do pó de $\mathrm{UO}_{2}$ garantem boa compatibilidade a verde da pastilha, assim como uma boa sinterabilidade. A área de superfície específica afeta diretamente o processo de sinterização. Já a densidade aparente e a escoabilidade afetam a 
etapa de compactação. As análises físicas estão dentro da especificação, validando o material para fabricação de pastilhas combustíveis.

É ressaltado que apesar das rigorosas especificações dos combustíveis nucleares, os resultados do produto final não serão confrontados com todas as especificações, uma vez que o propósito desse estudo se limita a estudar o comportamento do combustível referente ao processo de densificação. No entanto, o pó de $\mathrm{UO}_{2}$, por ser a principal matéria prima utilizada, acredita-se ser importante que sua caracterização esteja dentro das especificações, para que os resultados possam ser explicados de acordo com a literatura existente.

$\mathrm{Na}$ tabela 5, apresenta-se as características do pó comercial de $\mathrm{Er}_{2} \mathrm{O}_{3}$, enviado pelo fornecedor, que será adicionado ao $\mathrm{UO}_{2}$. As impurezas indicam teor abaixo de $0,1 \%$.

Através da análise de difração de raios x, indicada na figura 9, identificou-se a fase $\mathrm{UO}_{2}$, sistema cúbico de fase centrada (CFC), conhecido como rede fluorita, e a presença da fase $\mathrm{U}_{3} \mathrm{O}_{8}$, na concentração de $1 \%$, analisado pelo método de Rietveld. Esse método refina as estruturas cristalinas ajustando o difratograma obtido na análise com um padrão difratomérico, permitindo quantificar nesse estudo as porcentagens de fases presentes na amostra. A presença de $\mathrm{U}_{3} \mathrm{O}_{8}$ junto ao pó de $\mathrm{UO}_{2}$ não foi considerada significativa, uma vez que sua fração mássica é baixa e no combustível nuclear esse material faz parte da composição inicial e é adicionado na proporção de $12 \%{ }^{126 /}$. Os picos obtidos na difração estão de acordo com o cartão PDF (Powder Diffraction File) número $41-1422^{/ 49 /}$.

A análise do óxido de érbio indicou somente a fase $\mathrm{Er}_{2} \mathrm{O}_{3}$, com sistema cúbico de corpo centrado, de acordo com o grau de pureza fornecido pela empresa Alfa Easer. Pelo resultado obtido no difratograma na figura 10, verificou-se que está de acordo com o cartão PDF 08-0050 ${ }^{150 /}$. 
Figura 9: Espectro de raios x do pó de $\mathrm{UO}_{2}$

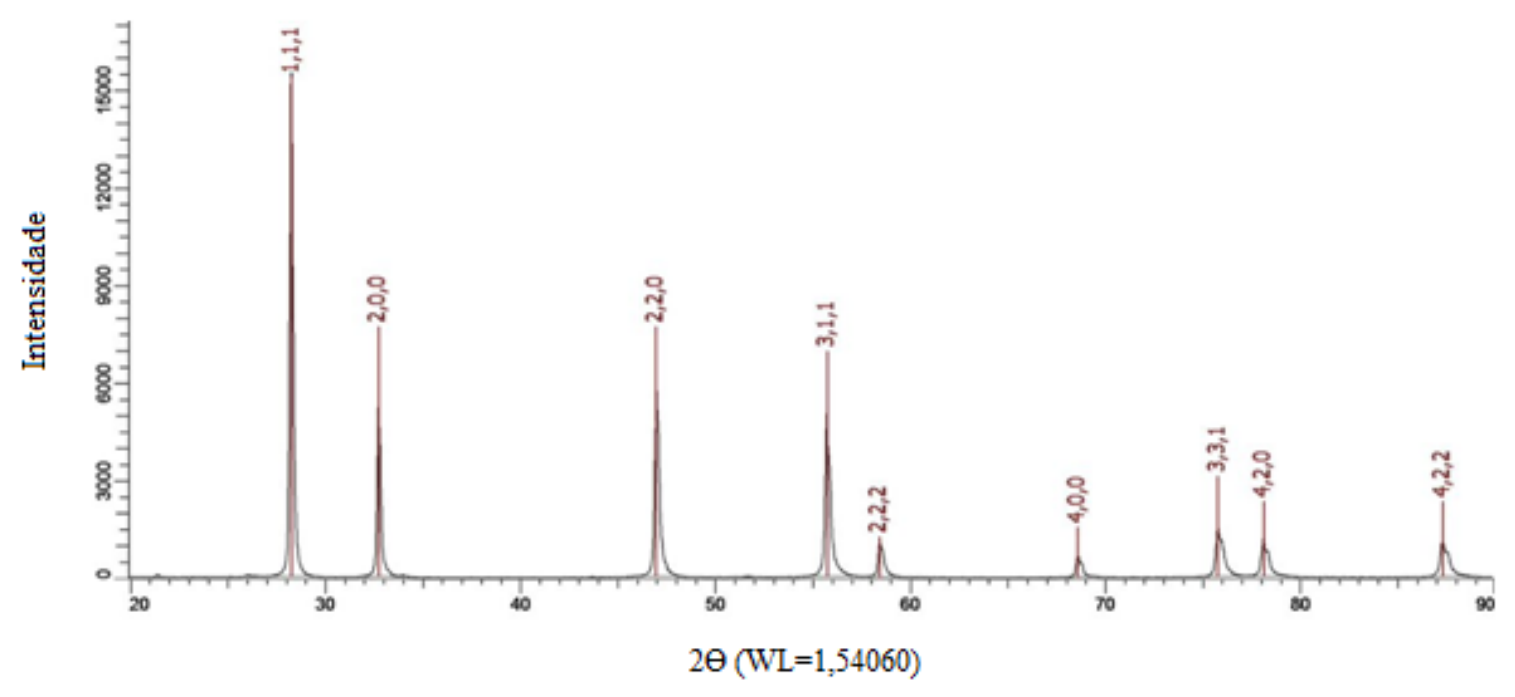

Fonte: Autor da dissertação

Figura 10: Espectro de raios $\mathrm{x}$ do pó de $\mathrm{Er}_{2} \mathrm{O}_{3}$

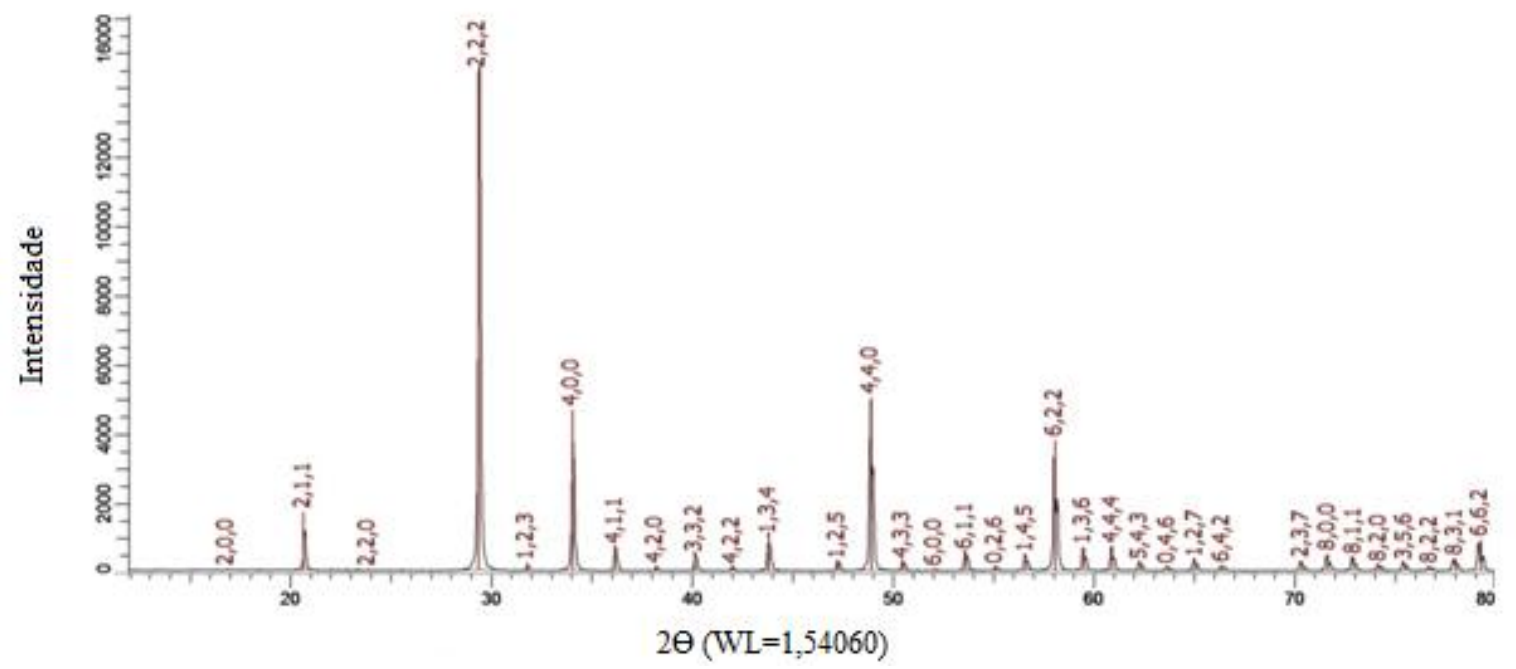

Fonte: Autor da dissertação

A morfologia e tamanho de partículas influenciam diretamente a área superficial, já que quanto maior a irregularidade da partícula e menor o seu tamanho, mais área de contato há disponível no material. A superfície é a região da partícula por onde 
ocorre o processo de difusão e por isso são parâmetros que influenciaram diretamente na etapa de sinterização. Características como escoabilidade e densidade solta influenciaram diretamente na etapa de compactação, pois a forma como o pó preenche a cavidade da matriz e o volume ocupado pelo material antes de ser compactado determinam a pressão com que o pulsão pressionará o pó, para que a densidade a verde seja atingida.

As características microestruturais foram analisadas por microscopia eletrônica de varredura e microscopia eletrônica de transmissão apresentadas nas Figuras 11 e 12.

As análises realizadas pelo microscópio eletrônico de varredura apresentam as características morfológicas das partículas. As tensões utilizadas estão entre 5 e $20 \mathrm{kV}$ e os aumentos de 500 e 1.000 vezes.

$\mathrm{O}$ pó de $\mathrm{UO}_{2}$, conforme visto na figura 11, apresenta aglomerados com cantos arredondados, dimensões na proporção 1:1 ou 1:3 tipicamente do pó oriundo do TCAU, como visto em vasta literatura ${ }^{16,9,26 /}$. O pó de $\operatorname{Er}_{2} \mathrm{O}_{3}$, conforme visto na figura 12 possui partículas irregulares, angulares e com aparência de cristal.

A determinação do tamanho médio de partículas dos pós de $\mathrm{UO}_{2}$ e $\mathrm{Er}_{2} \mathrm{O}_{3}$ foi obtida pela técnica de laser, indicando valores de 30,04 $\mu \mathrm{m}$ para o $\mathrm{UO}_{2}$ e $11,04 \mu \mathrm{m}$ para o $\mathrm{Er}_{2} \mathrm{O}_{3}$. Esses valores correspondem ao D50. Ou seja, até 50\% das partículas possuem os valores mencionados.

Nas figuras 13 e 14, são apresentados a distribuição do tamanho de partícula para os dois pós. Observa-se que para o pó de $\mathrm{Er}_{2} \mathrm{O}_{3}$, devido a partículas muito finas existentes, registra-se na análise uma distribuição bimodal. Essa diferença de tamanho entre as partículas de $\mathrm{UO}_{2}$ e $\mathrm{Er}_{2} \mathrm{O}_{3}$ também ajuda no empacotamento das partículas ${ }^{1 / 4 /}$, uma vez que os espaços vazios formados entre as partículas podem ser preenchidos por partículas de tamanho menor. 
Figura 11: Micrografia do pó de $\mathrm{UO}_{2}$ por microscopia eletrônica de varredura
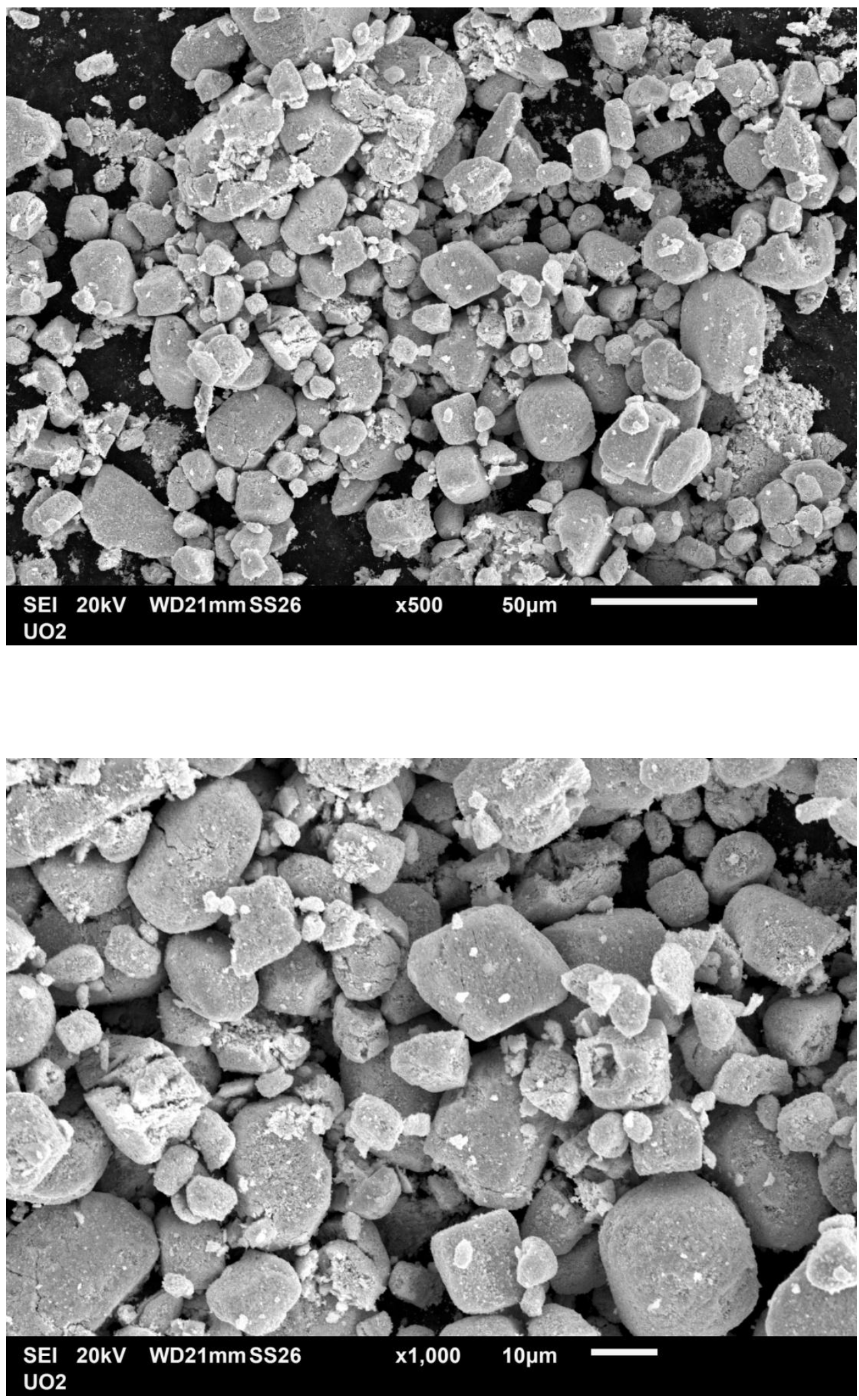

Fonte: Autor da dissertação 
Figura 12: Micrografia do pó de $\mathrm{Er}_{2} \mathrm{O}_{3}$ por microscopia eletrônica de varredura
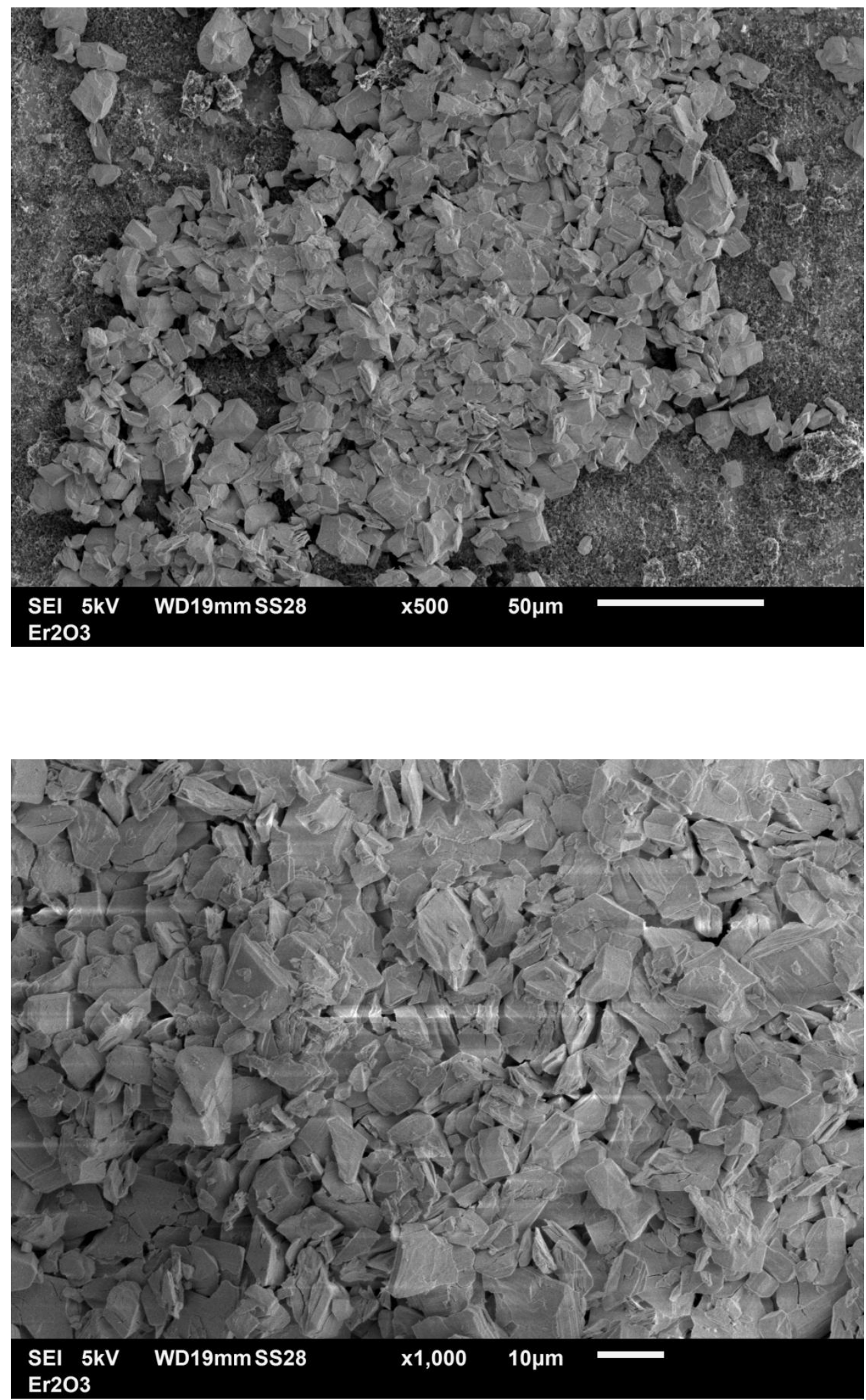

Fonte: Autor da dissertação 
Figura 13: Distribuição granulométrica do pó de $\mathrm{UO}_{2}$ pela técnica de difração a laser

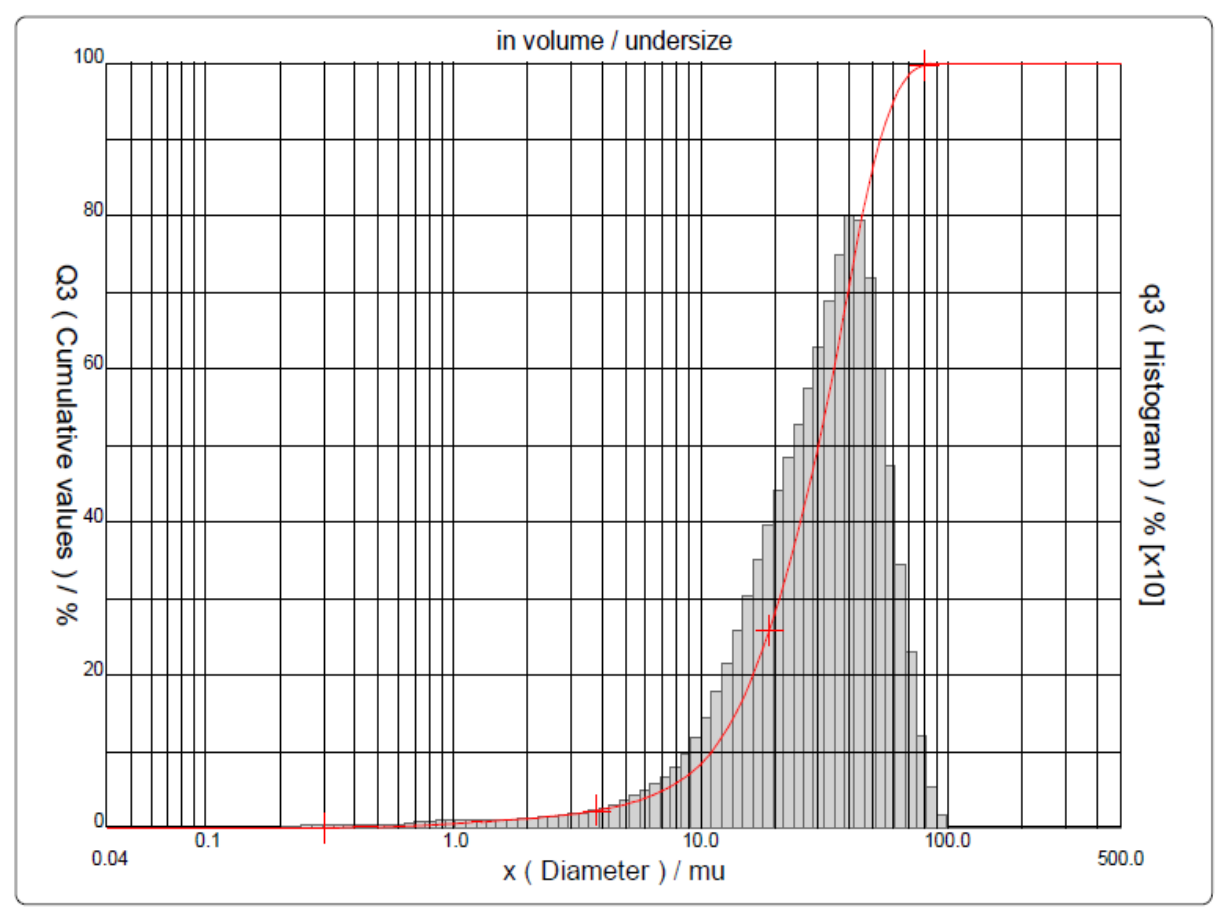

Fonte: Autor da dissertação

Figura 14: Distribuição granulométrica do pó de $\mathrm{Er}_{2} \mathrm{O}_{3}$ pela técnica de difração a laser

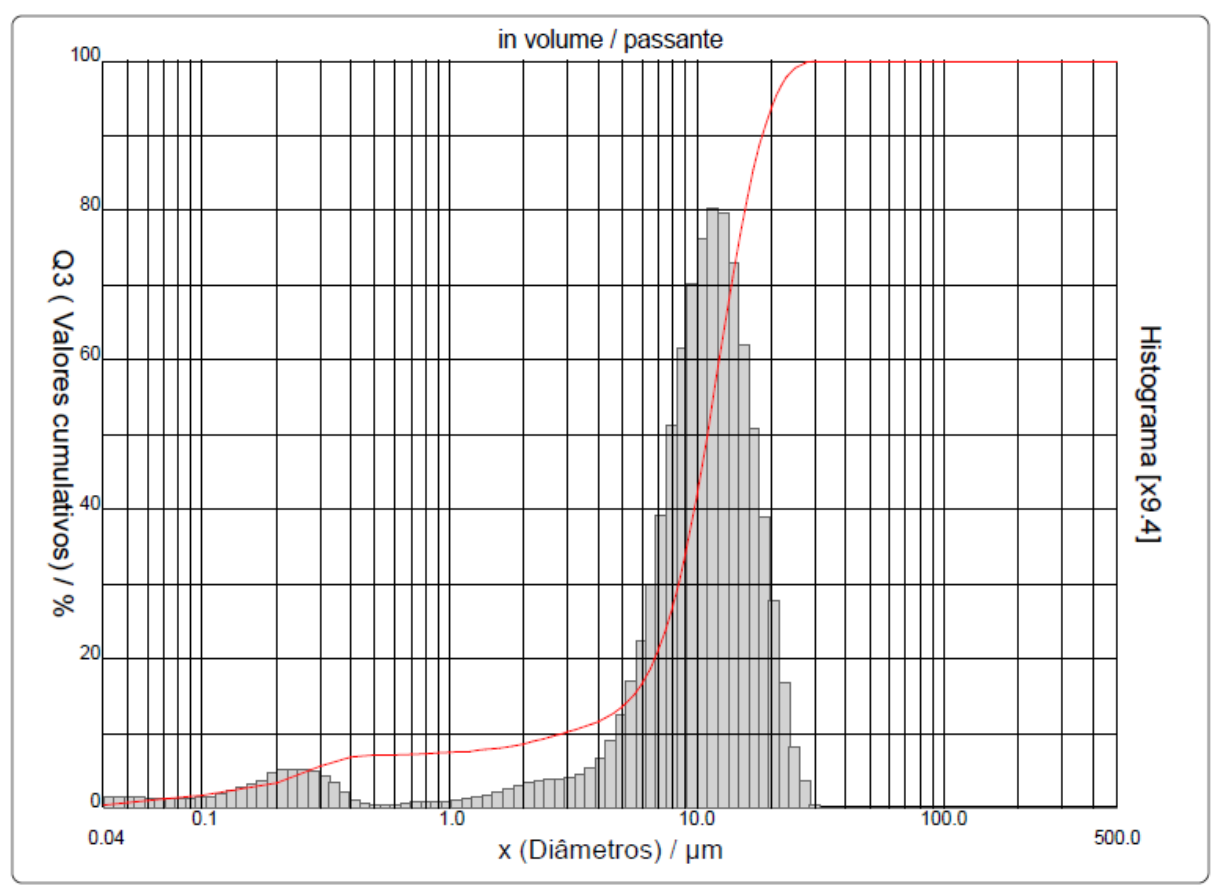

Fonte: Autor da dissertação 
$\mathrm{O}$ pó de $\mathrm{UO}_{2}$ apresentou escoabilidade, densidade solta e batida adequadas para a etapa de compactação. $\mathrm{O}$ pó de $\mathrm{UO}_{2}$ foi proveniente do TCAU, que tem como característica um precipitado com forma arredondada e tamanho de partícula grande, o que é suficiente para conferir ao pó uma boa escoabilidade. Quando o TCAU é reduzido a $\mathrm{UO}_{2}$ a forma do pó de $\mathrm{UO}_{2}$, obtido mantém a forma original do pó precursor, possuindo uma alta escoabilidade além de uma alta sinterabilidade. Devido a estas características este pó pode ser compactado diretamente, com ausência de trincas, na densidade desejada, não sendo necessárias as etapas de moagem, pré-compactação, granulação e peneiramento. A sinterabilidade é suficiente devido à alta superfície especifica obtida, de cerca de $5,0 \mathrm{~m}^{2} / \mathrm{g}$.

\subsection{Obtenção das pastilhas a verde}

Após a caracterização da matéria prima, foi preparado o pó para a produção das pastilhas a verde de $\mathrm{UO}_{2}$ e $\mathrm{UO}_{2}-\mathrm{Er}_{2} \mathrm{O}_{3}$. Após a mistura, o pó foi colocado no ferramental de compactação, com massa e pressão de compactação adequada para que a densidade geométrica da pastilha esteja em 50,5\% \pm 0,5 da densidade teórica da mistura, conforme apresentado na tabela 6 . A densidade a verde das pastilhas pode ser alterada, variando a pressão de compactação. A densidade teórica das misturas de pós foi calculada utilizando a equação 9 e a porcentagem da densidade teórica é a razão entre as duas densidades.

Tabela 6: Densidade geométrica das pastilhas verdes

\begin{tabular}{lccc}
\hline \multicolumn{1}{c}{ Pastilha } & $\begin{array}{c}\text { Densidade a verde } \\
\left(\mathrm{g} / \mathrm{cm}^{3}\right)\end{array}$ & $\begin{array}{c}\text { Densidade teórica } \\
\text { da mistura }\left(\mathrm{g} / \mathrm{cm}^{3}\right)\end{array}$ & $\begin{array}{c}\text { \% Densidade } \\
\text { teórica }\end{array}$ \\
\hline $\mathrm{UO}_{2}$ & 5,55 & 10,95 & 50,68 \\
$\mathrm{UO}_{2} .1,0 \% \mathrm{Er}_{2} \mathrm{O}_{3}$ & 5,50 & 10,92 & 50,37 \\
$\mathrm{UO}_{2} .2,5 \% \mathrm{Er}_{2} \mathrm{O}_{3}$ & 5,47 & 10,87 & 50,32 \\
$\mathrm{UO}_{2} .4,0 \% \mathrm{Er}_{2} \mathrm{O}_{3}$ & 5,50 & 10,83 & 50,78 \\
$\mathrm{UO}_{2} .9,8 \% \mathrm{Er}_{2} \mathrm{O}_{3}$ & 5,39 & 10,67 & 50,52 \\
\hline
\end{tabular}

Fonte: autor da dissertação 


\subsection{Sinterização das pastilhas}

O resultado da sinterização realizada no dilatômetro pode ser avaliado por meio do gráfico ilustrado na figura 15 , onde se relaciona a temperatura e a retração. No eixo das abscissas existe as unidades temperatura e tempo. A disposição dessas informações indica o programa de aquecimento utilizado, com o aumento de temperatura até $1700{ }^{\circ} \mathrm{C}$ e o patamar mantido nessa temperatura por 3 horas, onde é iniciado o resfriamento do equipamento. Os eixos das ordenadas apresentam a curva de retração (lado esquerdo) e a taxa de retração (lado direito).

Figura 15: Curva de sinterização e taxa de retração da pastilha de $\mathrm{UO}_{2}$ puro

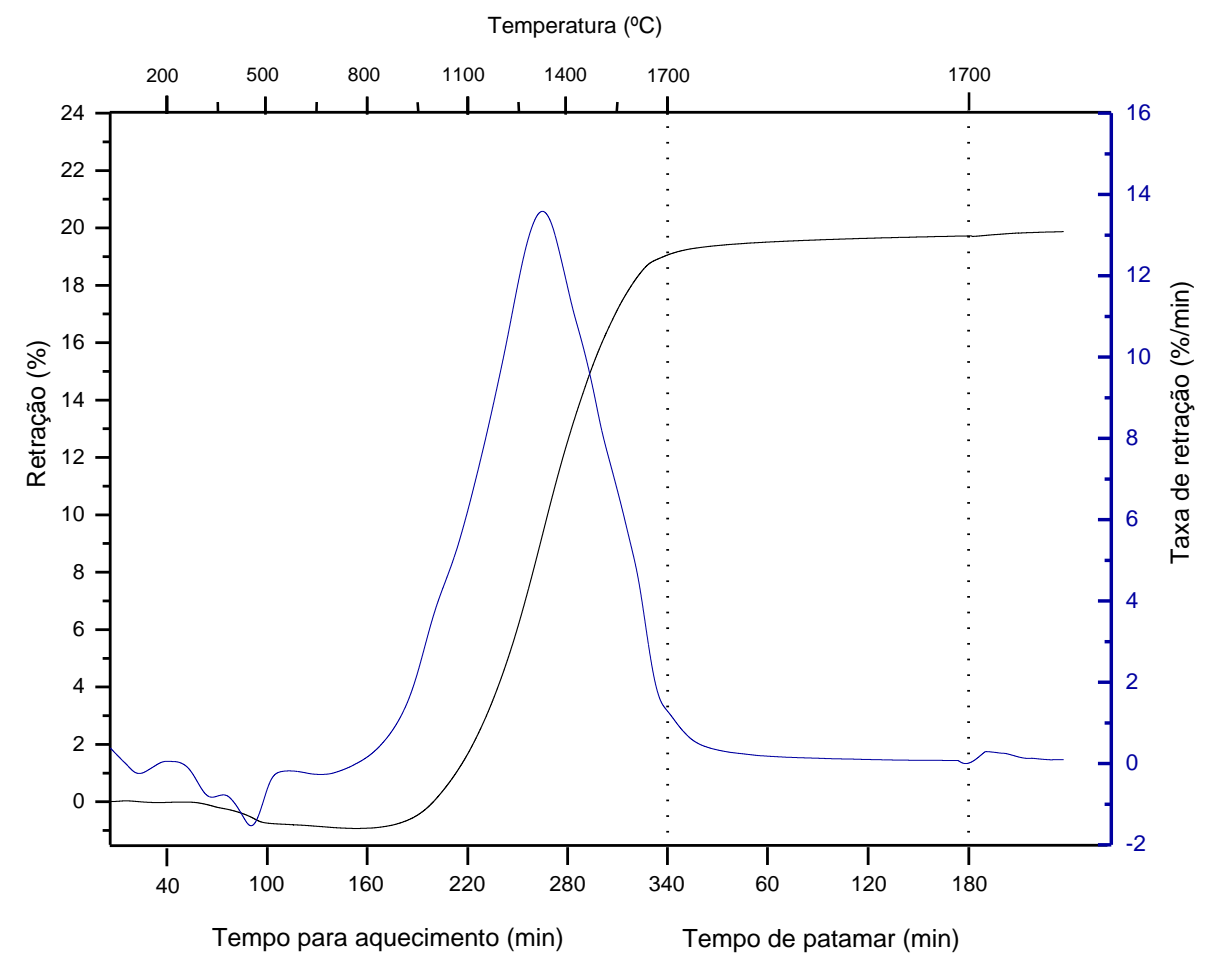

Fonte: Autor da dissertação

Pode-se verificar na figura 15 que, antes da retração, ocorre uma expansão quando a temperatura está próxima a $300^{\circ} \mathrm{C}$. Essa expansão se deve à relação $\mathrm{O} / \mathrm{U}$. $\mathrm{O}$ aumento da concentração de oxigênio na célula unitária faz com que seu parâmetro de rede diminua $^{128,52 /}$. Com a atmosfera redutora, a concentração de oxigênio diminui, fazendo com 
que a relação $\mathrm{O} / \mathrm{U}$ também diminua até 2 , aumentando o parâmetro de rede e causando a expansão inicial. Após esse período, ocorre a retração principal quando a temperaturas está próxima a $800^{\circ} \mathrm{C}$ e termina quando a temperatura está no patamar de $1700{ }^{\circ} \mathrm{C}$ a cerca de 30 minutos. No fim desse período há uma tendência à estabilização, chegando ao fim do resfriamento com a retração de $19,87 \%$.

A taxa de retração, derivada da curva de sinterização, é outro fator importante para esse estudo. Nela, pode-se identificar o início e fim da retração. O único pico formado na taxa de retração indica que a densificação foi ocasionada apenas pela diminuição da porosidade.

A difusão é a migração em etapas dos átomos de um sítio para outro. No caso do sistema urânio-érbio, os átomos de urânio são substituídos pelos de érbio, formando uma solução sólida substitucional na rede cristalina do tipo fluorita do $\mathrm{UO}_{2}$. Para que ocorra esse tipo de movimento, o átomo deve ter energia suficiente para se deslocar, de natureza vibracional e dependente da temperatura ${ }^{1 / 21}$.

Os componentes relacionados na mistura mecânica de pós se difundem simultaneamente. Se a taxa de difusão das duas partículas $\mathrm{UO}_{2}$ e $\mathrm{Er}_{2} \mathrm{O}_{3}$ não for a mesma, o efeito Kirkendall acontece. O efeito Kirkendall ocorre quando há uma diferença na velocidade de difusão, havendo um transporte de massa e de vazios, como já observado no sistema $\mathrm{UO}_{2}-\mathrm{Gd}_{2} \mathrm{O}_{3}$. Os cátions $\mathrm{Gd}^{3+}$ se difundem mais rapidamente na fase $\mathrm{UO}_{2}$ que o oposto, estabelecendo um fluxo maior de gadolínio derivado dos aglomerados de $\mathrm{Gd}_{2} \mathrm{O}_{3}$ em direção à fase de $\mathrm{UO}_{2}$, quando comparado com o fluxo de urânio em direção aos aglomerados de $\mathrm{Gd}_{2} \mathrm{O}_{3}$. Esse processo faz com que o $\mathrm{UO}_{2}$ se expanda para receber os

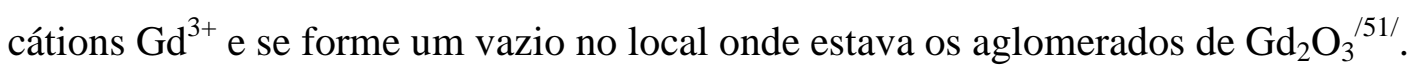

O fluxo de difusão é inversamente proporcional à área, por onde ocorre a difusão, conforme a equação 11. Portanto, quanto maiores são os aglomerados, maior a área de difusão e menor o fluxo de difusão, potencializando o efeito Kirkendall. Dessa forma, quanto mais homogênea for a mistura, menor a ocorrência de aglomerados e menor o efeito Kirkendall.

$$
D=\frac{1}{A} \frac{d M}{d t}
$$


Na figura 16, é mostrado as curvas de sinterização obtidas. Cada curva representa uma fração mássica de $\mathrm{Er}_{2} \mathrm{O}_{3}$. A curva com $\mathrm{UO}_{2}$ puro foi deixada como referência. Nota-se que a retração total das pastilhas diminui com o aumento da concentração mássica de $\mathrm{Er}_{2} \mathrm{O}_{3}$. Porém, com exceção da pastilha com 9,8\% em massa de $\mathrm{Er}_{2} \mathrm{O}_{3}$, todas tiveram retração maior que a pastilha com $\mathrm{UO}_{2}$ puro.

Sugere-se que quanto maior a proporção do pó de óxido de érbio adicionado à mistura, maior a tendência a aglomerar, formando mais poros, e diminuindo a retração, o que explica as curvas de sinterização. Portanto, esse resultado sugere a confirmação da premissa inicial, que o tamanho dos aglomerados influencia na formação de porosidade e, portanto, na retração do material.

Figura 16: Curvas de sinterização das pastilhas $\mathrm{UO}_{2}$ e $(\mathrm{U}, \mathrm{Er}) \mathrm{O}_{2}$

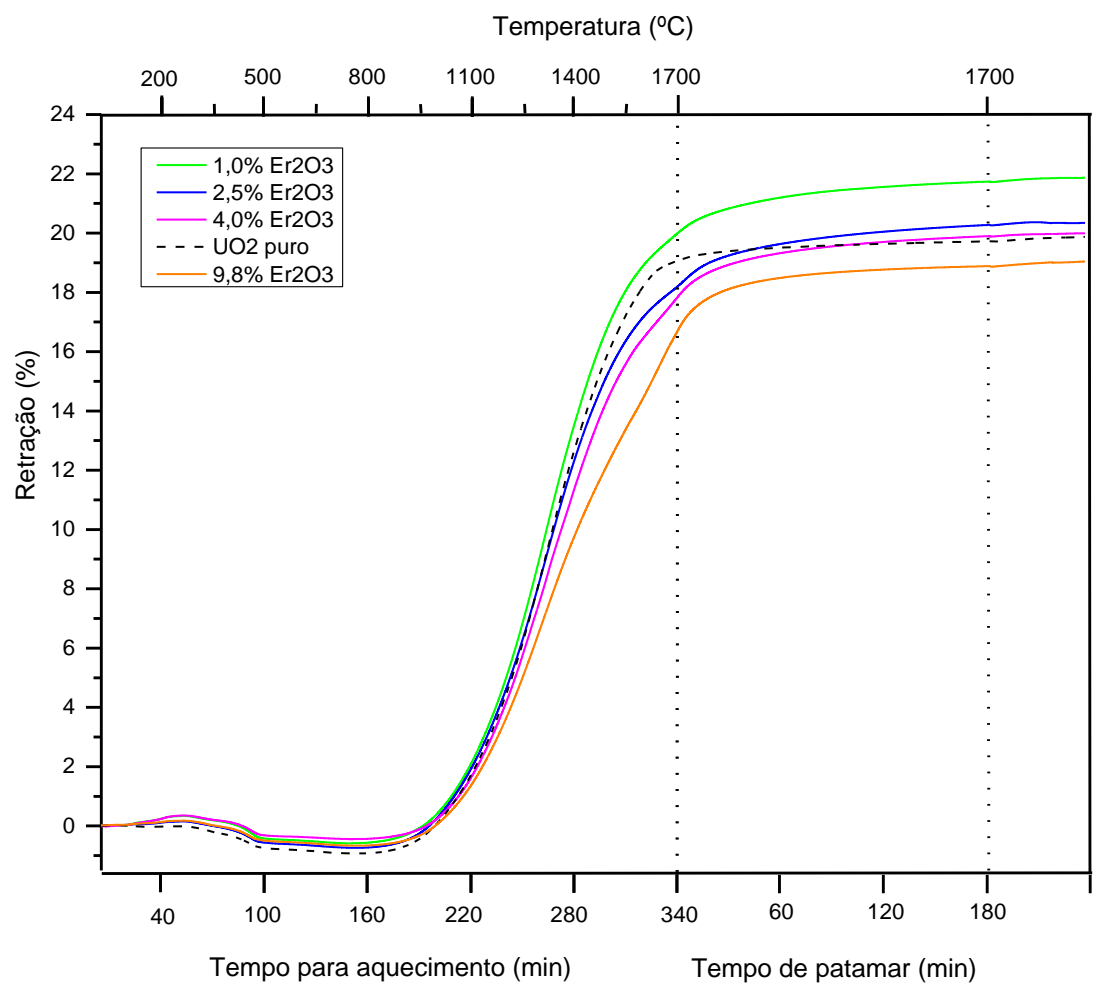

Fonte: Autor da dissertação

Em todas as curvas foi evidenciado um bloqueio na sinterização, o qual foi observado em trabalhos estudando a densificação do sistema $\mathrm{UO}_{2}-\mathrm{Gd}_{2} \mathrm{O}_{3}{ }^{19,23,51,53 /}$, 
conforme pode ser visto na figura 17. Nesse trabalho, o processo de sinterização é bloqueado e a densificação é deslocada na direção de maiores temperaturas ${ }^{123 /}$. A inflexão na curva de sinterização é característica desse bloqueio, fazendo com que a retração diminua com a adição de $\mathrm{Gd}_{2} \mathrm{O}_{3}$, pois a inflexão na curva de sinterização se torna cada vez mais acentuado. No sistema $\mathrm{UO}_{2}-\mathrm{Er}_{2} \mathrm{O}_{3}$ essa inflexão é menos pronunciada, sendo melhor evidenciada para alta concentração do óxido de érbio, porém também ocorre.

Figura 17: Curvas de sinterização das pastilhas de $\mathrm{UO}_{2}$ e $(\mathrm{U}, \mathrm{Gd}) \mathrm{O}_{2}$

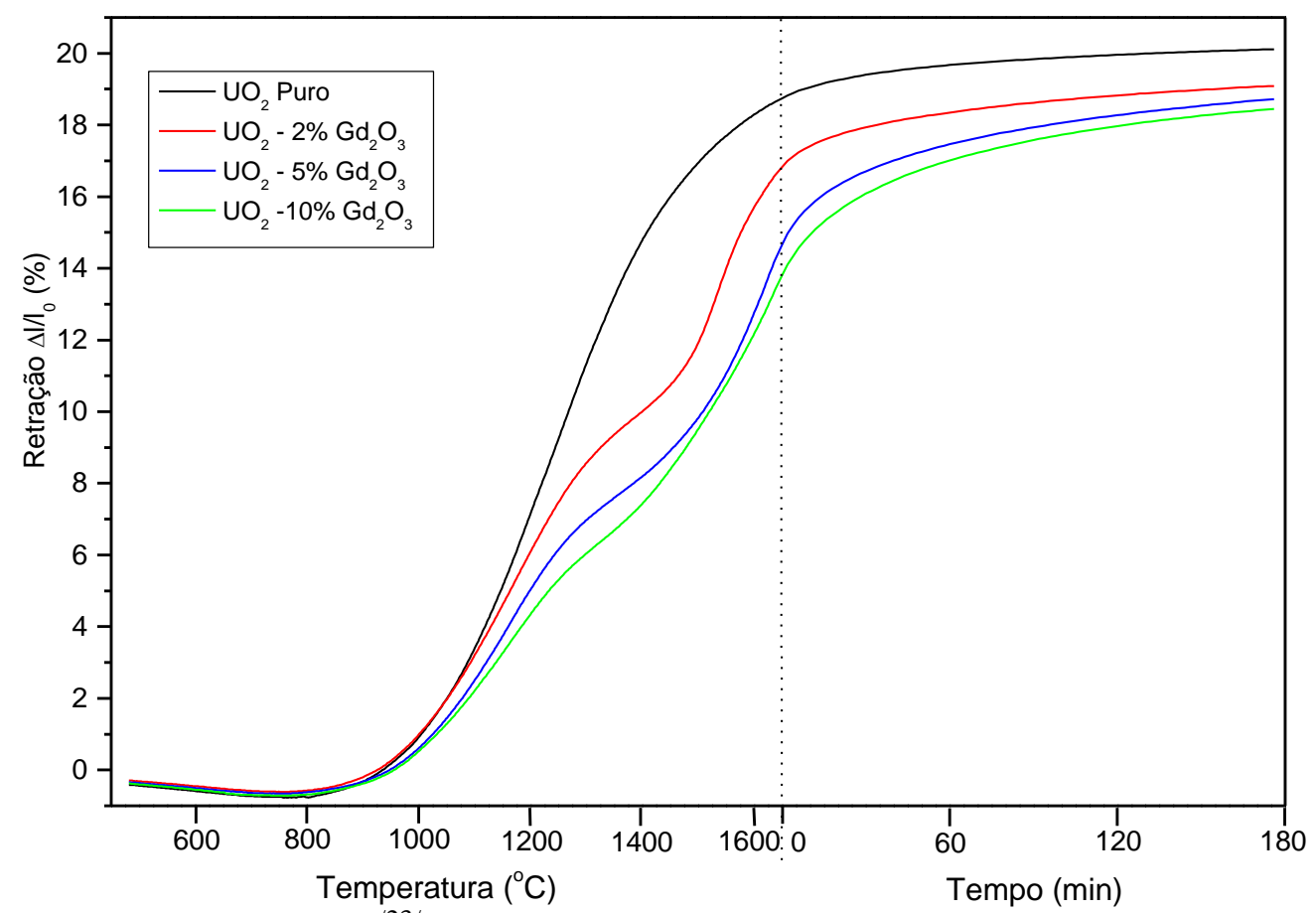

Fonte: Durazzo et al, $2013^{123 /}$

Uma explicação proposta para o bloqueio na sinterização no sistema $\mathrm{UO}_{2-}$ $\mathrm{Gd}_{2} \mathrm{O}_{3}$ é a ocorrência do efeito Kirkendall ${ }^{/ 23 /}$. Causado pela diferença entre de difusividade do gadolínio na estrutura cristalina do $\mathrm{UO}_{2}$ e do urânio na estrutura cristalina do $\mathrm{Gd}_{2} \mathrm{O}_{3}$. Essa diferença cria poros a alta temperatura, que dificilmente são eliminados nos estágios mais adiantados da sinterização, causando a inflexão na curva de sinterização. Provavelmente esse mesmo mecanismo está ocorrendo no sistema $\mathrm{UO}_{2}-\mathrm{Er}_{2} \mathrm{O}_{3}$, porém de forma menos intensa, tendo em vista as inflexões nas curvas das figuras 16 e 17. 
Conforme as equações 4 e 5 , a adição do $\mathrm{Gd}_{2} \mathrm{O}_{3}$ causa uma diminuição maior da densidade com relação à adição do $\mathrm{Er}_{2} \mathrm{O}_{3}$. Assim como no cálculo da densidade teórica, essa perspectiva também se confirma com relação à pastilha sinterizada. As curvas de sinterização do $(\mathrm{U}, \mathrm{Er}) \mathrm{O}_{2}$ (figura 16) e $(\mathrm{U}, \mathrm{Gd}) \mathrm{O}_{2}$ (figura 17$)$ indicam que a retração da primeira em relação à segunda é maior. Essa situação tem duas prováveis causas. A diferença entre o raio atômico do $\mathrm{Er}^{3+}$ e $\mathrm{Gd}^{3+}$ e a forma como as partículas de $\mathrm{Er}_{2} \mathrm{O}_{3}$ e $\mathrm{Gd}_{2} \mathrm{O}_{3}$ se aglomeram.

Essa afirmação se sustenta mesmo se a condição de sinterização diferir em relação ao patamar de temperatura. A curva 17 foi obtida com o patamar de $1650^{\circ} \mathrm{C}$, porém outros resultados utilizando o sistema $\mathrm{UO}_{2}-\mathrm{Gd}_{2} \mathrm{O}_{3}$ demonstram que essa diferença de temperatura não é significativa quanto aos resultados de retração da pastilha ${ }^{19 /}$.

Pode-se considerar que o érbio causa o mesmo efeito do que o gadolínio quando se solubiliza na estrutura cristalina do $\mathrm{UO}_{2}$, onde o cátion $\mathrm{Gd}^{3+}$ substitui o $\mathrm{U}^{4+}$. Nesse processo, para neutralização eletrônica, ocorre a oxidação do $\mathrm{U}^{4+}$ para $\mathrm{U}^{5+}$. Como os íons de urânio de maior valência possuem um raio atômico menor, essa mudança causa um aumento da difusividade e, por conseguinte, um aumento na sinterização ${ }^{151 /}$.

A tabela 7 mostra os raios atômicos dos principais cátions envolvidos na solução sólida. O raio atômico do cátion $\mathrm{Er}^{3+}$ é ligeiramente maior que o $\mathrm{U}^{4+}$, fazendo com que o parâmetro de rede da estrutura cristalina do $\mathrm{UO}_{2}$ aumente com a formação da solução sólida (U,Er) $\mathrm{O}_{2}$, porém a oxidação do cátion $\mathrm{U}^{4+}$ pelo $\mathrm{U}^{5+}$ faz com que a somatória desses eventos formem um parâmetro de rede menor, já que seu valor é mais relevante.

Tabela 7: Raio atômico

\begin{tabular}{lcccc}
\hline Cátion & $\mathrm{U}^{4+}$ & $\mathrm{U}^{5+}$ & $\mathrm{Er}^{3+}$ & $\mathrm{Gd}^{3+}$ \\
\hline Raio atômico $(\mathrm{nm})$ & 0.1001 & 0.0880 & 0.1004 & 0.1053 \\
\hline
\end{tabular}

Fonte: Fedotov et al, $2013^{/ 30 /}$ 


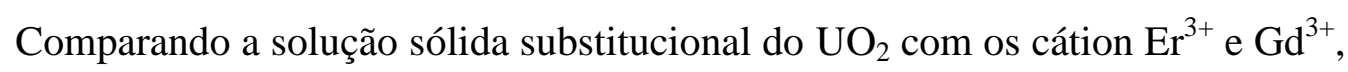
nota-se que o segundo deforma mais a estrutura, já que seu raio atômico é maior e o raio atômico do $\mathrm{Er}^{3+}$ é muito próximo ao $\mathrm{U}^{4+}$. Essa diferença traz impacto na densidade da pastilha, fazendo com que o parâmetro de rede, e consequentemente, o volume da céula unitária seja menor com a substituição do cátion $\mathrm{U}^{4+}$ pelo $\mathrm{Er}^{3+}$, do que pelo $\mathrm{Gd}^{3+}$. Esse é um primeiro fator que faz com que a retração da mistura $\mathrm{UO}_{2}-\mathrm{Er}_{2} \mathrm{O}_{3}$ seja maior que a mistura $\mathrm{UO}_{2}-\mathrm{Gd}_{2} \mathrm{O}_{3}$. Além disso, as curvas de sinterização apresentadas nas figuras 16 e 17 mostram uma inflexão maior quando se adiciona o $\mathrm{Gd}_{2} \mathrm{O}_{3}$ em relação ao $\mathrm{Er}_{2} \mathrm{O}_{3}$. Essa inflexão ocorre provavelmente por uma tendência maior de aglomeração dos pós de $\operatorname{Gd}_{2} \mathrm{O}_{3}$ e os pós de $\mathrm{Er}_{2} \mathrm{O}_{3}$ possuem uma tendência menor em se aglomerar, podendo ser melhor homogeneizados, diminuindo o efeito Kirkendall.

As curvas da taxa de retração, mostradas na figura 18, são derivadas das curvas de sinterização apresentadas na figura 16.

Figura 18: Taxa de retração das curvas de sinterização das pastilhas de $\mathrm{UO}_{2}$ e (U,Er) $\mathrm{O}_{2}$

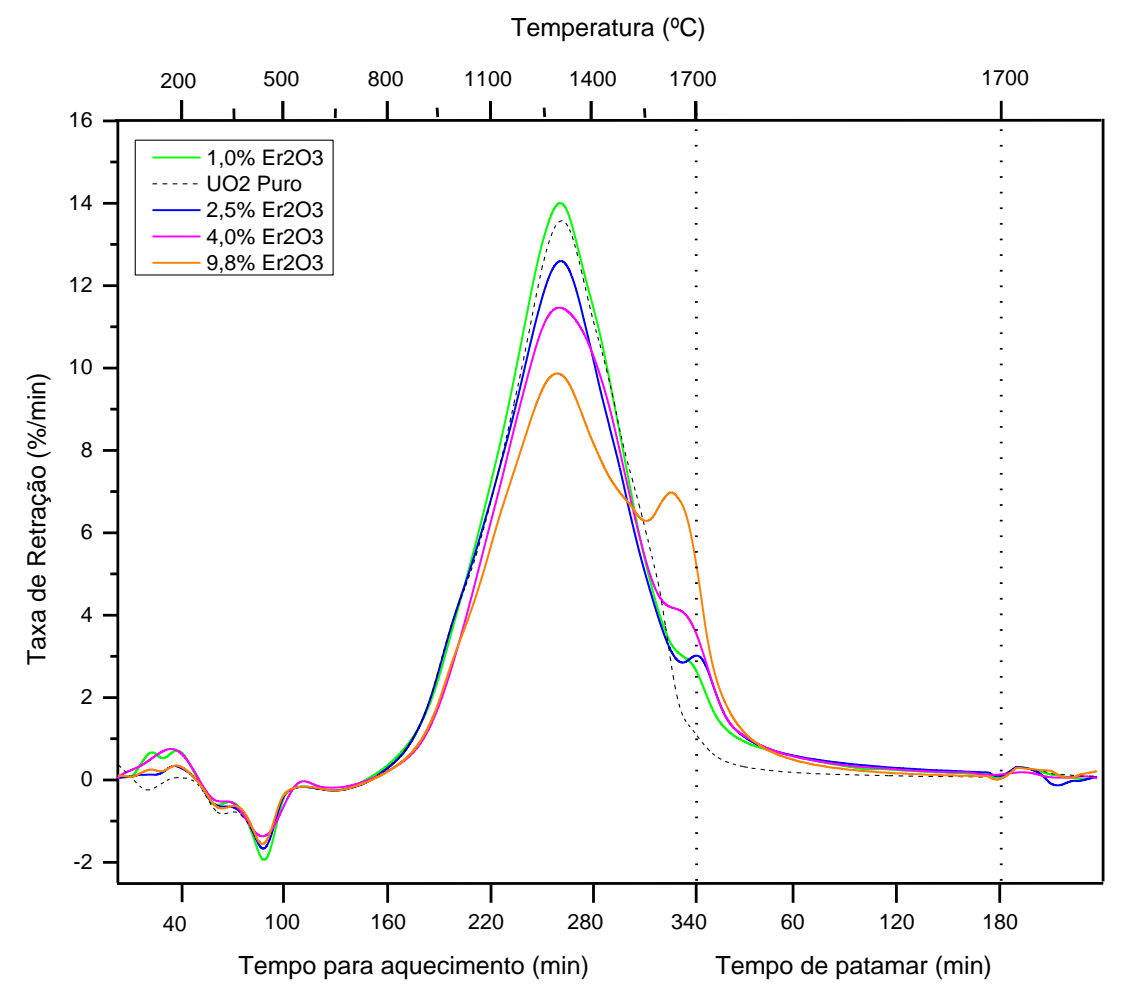

Fonte: Autor da dissertação 
Percebe-se a diferença entre as curvas com adição do érbio e com o $\mathrm{UO}_{2}$ puro, onde aparece apenas 1 pico de retração. Provavelmente essa inflexão se deve à solubilização do érbio na estrutura cristalina do $\mathrm{UO}_{2}$, como ocorre no caso do gadolínio, mostrado na figura $19^{/ 23 /}$. Próximo à temperatura de $1550^{\circ} \mathrm{C}$, a solubilização do érbio na estrutura cristalina em maior volume causa um novo pico de retração. Esse novo pico de retração aumenta, à medida que se aumenta a concentração de $\operatorname{Er}_{2} \mathrm{O}_{3}$, e se deve principalmente à formação do cátion $\mathrm{U}^{5+}$, quando o cátion $\mathrm{Er}^{3+}$ substitui o $\mathrm{U}^{4+}$. As ações combinadas resultam nas curvas apresentadas na figura 16 e 18.

Com exceção da mistura com $1 \%$ em massa de $\mathrm{Er}_{2} \mathrm{O}_{3}$, todas foram menores que o $\mathrm{UO}_{2}$ puro, entre as temperaturas de $900^{\circ} \mathrm{C}$ e $1500^{\circ} \mathrm{C}$. Na mistura com $1 \%$ em peso, como existe baixa fração mássica de $\mathrm{Er}_{2} \mathrm{O}_{3}$, há um aumento da taxa de sinterização, que indica uma boa homogeneidade dessas partículas pela mistura. À medida que vai sendo aumentada a fração mássica de $\mathrm{Er}_{2} \mathrm{O}_{3}$, essa homogeneidade vai diminuindo, formando mais poros e diminuindo a taxa de retração.

As curvas da taxa de retração das pastilhas $\mathrm{UO}_{2}$ e $(\mathrm{U}, \mathrm{Gd}) \mathrm{O}_{2}$ são mostradas na figura 19. Maiores distorções das curvas de sinterização mostrada na figura 17 causam maiores picos na taxa de retração, desta vez pela incorporação do cátion $\mathrm{Gd}^{3+}$ na rede do $\mathrm{UO}_{2}$. A temperatura em que esse evento começa a ocorrer é mais baixa que o érbio, porém permanece por mais tempo. 
Figura 19: Taxa de retração das curvas de sinterização das pastilhas de $\mathrm{UO}_{2}$ e (U,Gd) $\mathrm{O}_{2}$

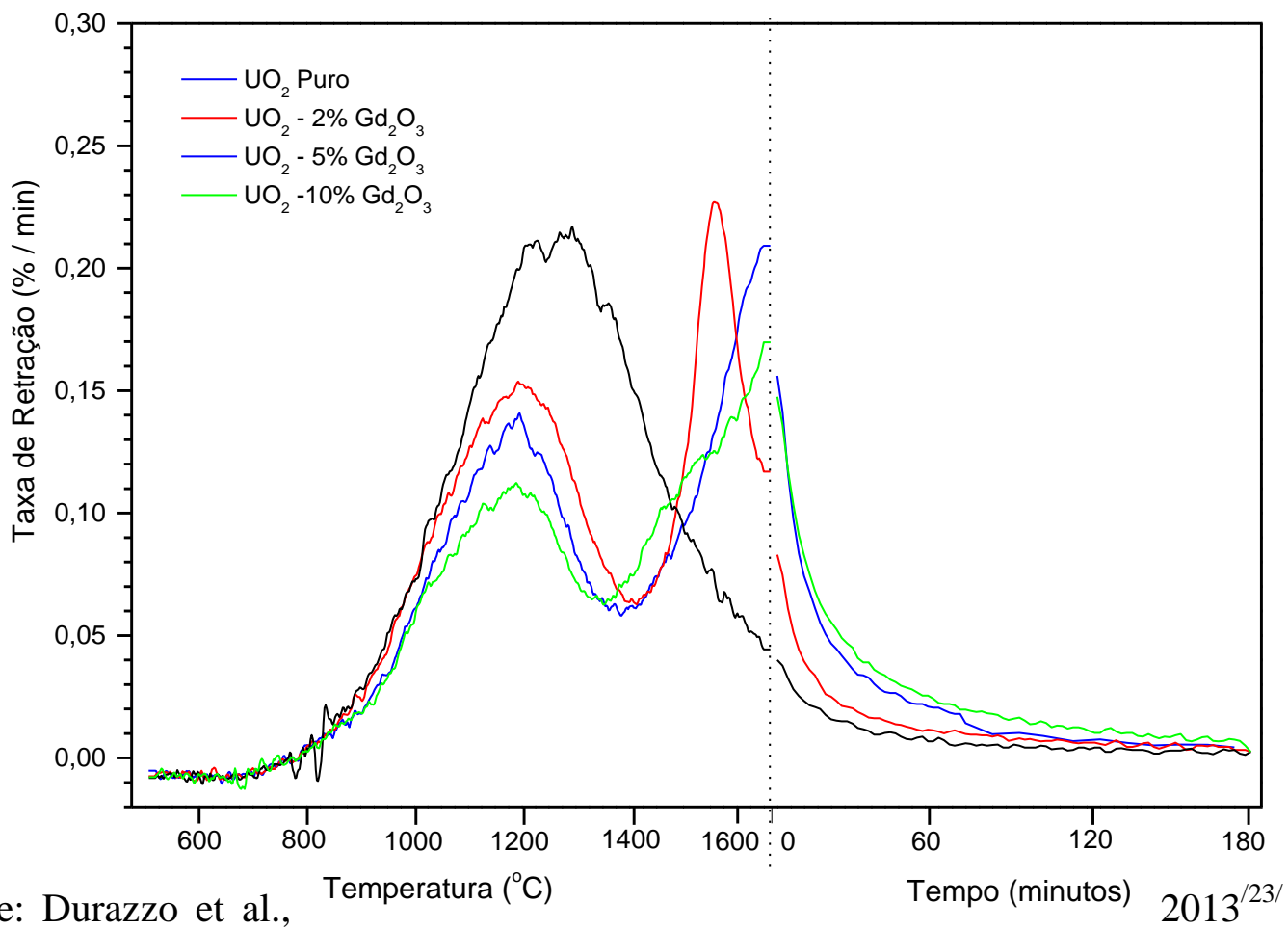

Na figura 20, é mostrado a taxa de retração da pastilha com 9,8\% de érbio na sua composição, em laranja, e foi colocada sobreposta com a análise térmica diferencial com um material de mesma composição, em azul, entre as temperaturas de $1100{ }^{\circ} \mathrm{C}$ e 1700 ${ }^{\circ} \mathrm{C}$, onde começa o patamar de sinterização. 
Figura 20: Análise térmica diferencial x taxa de retração

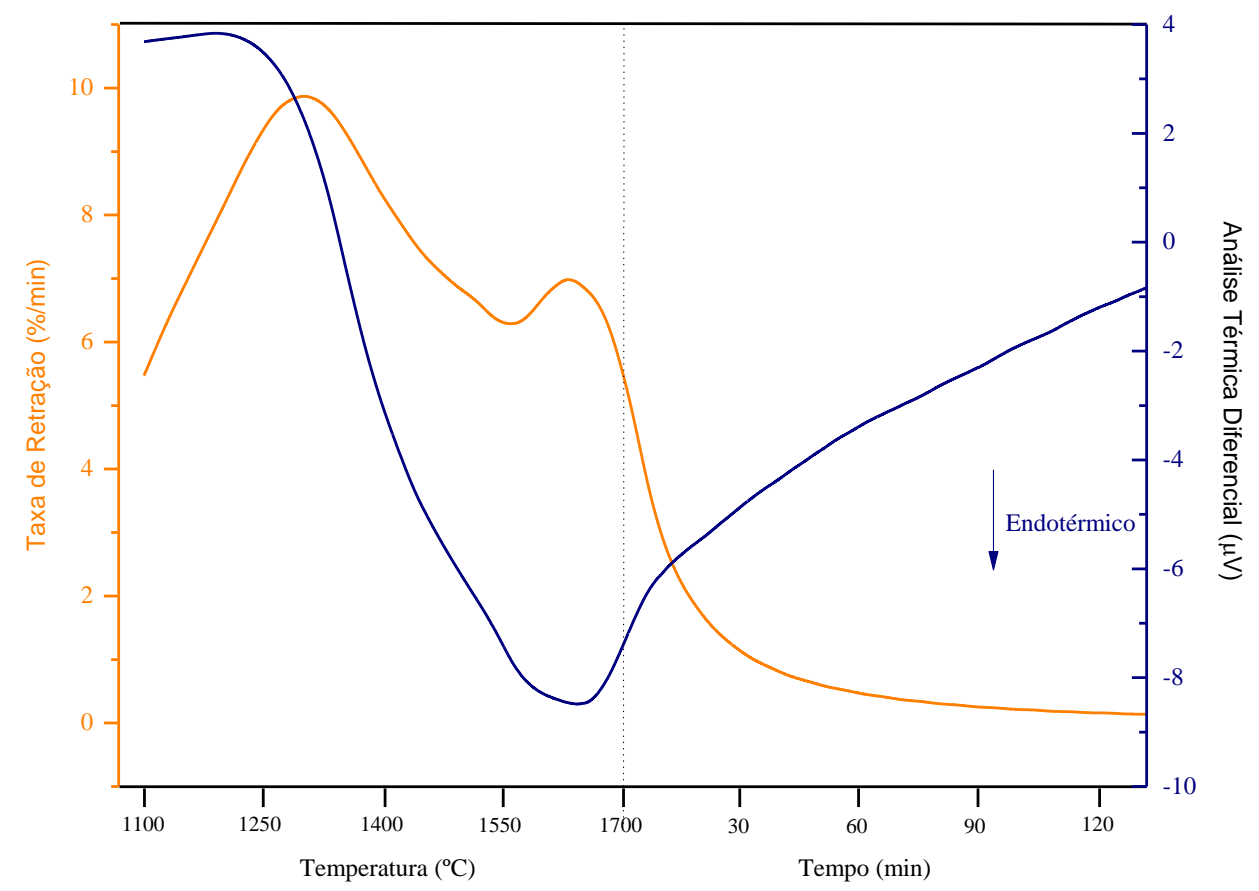

Fonte: Autor da dissertação

Percebe-se que na temperatura próxima a $1550{ }^{\circ} \mathrm{C}$ há um evento endotérmico. Esse evento é coincidente com a inflexão da taxa de retração, sendo, portanto, possivelmente a temperatura em que o érbio se difunde na estrutura cristalina do $\mathrm{UO}_{2} \mathrm{em}$ maior volume.

A retração tem um impacto direto sobre a densidade da pastilha, uma vez que a cinética de sinterização determina a quantidade de poros formados, como apresentado na figura 21. 
Figura 21: Porcentagem da densidade teórica da pastilha

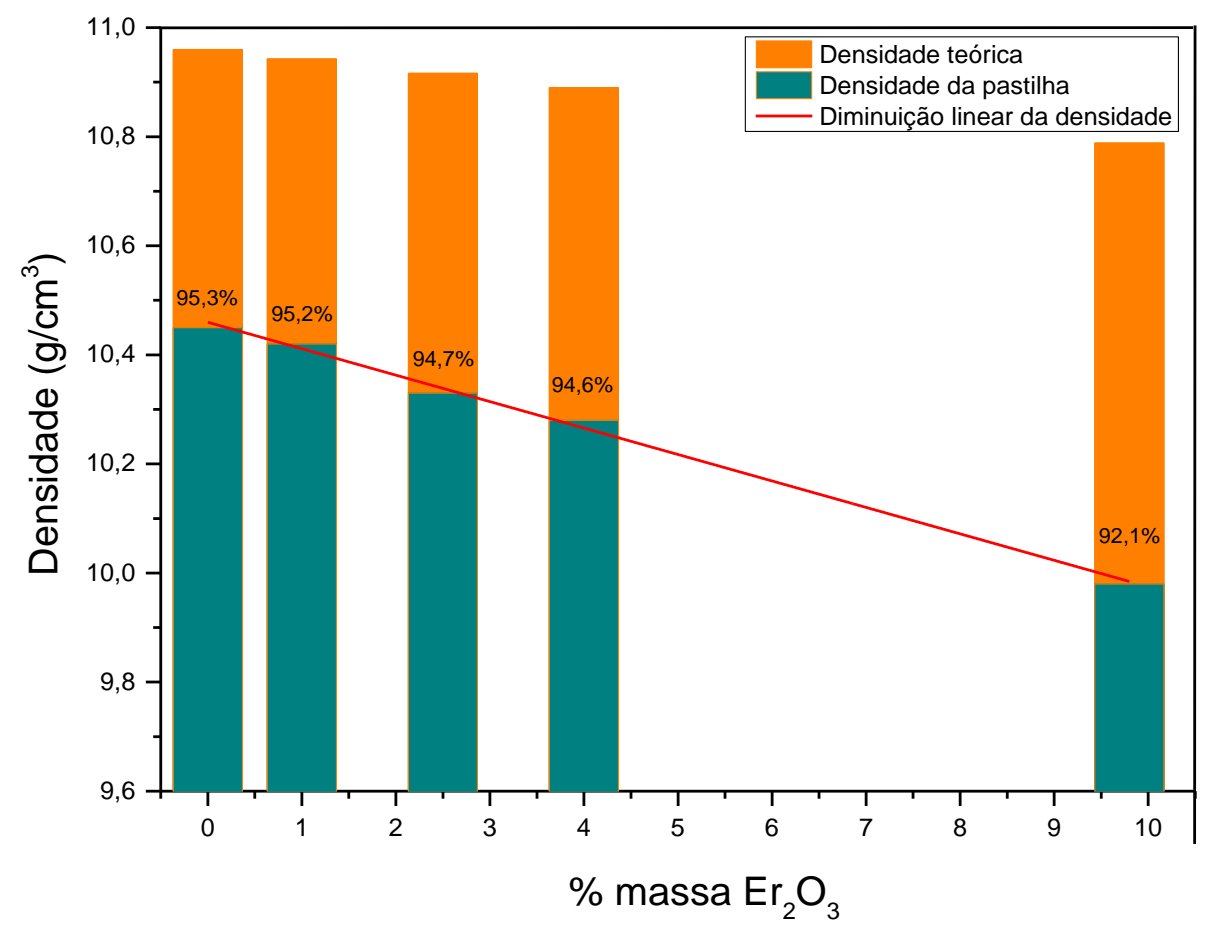

Fonte: Autor da dissertação

Na figura 21 são apresentados os valores de densidade obtido e calculado nesse estudo. A barra laranja representa a densidade teórica do $\mathrm{UO}_{2}$ puro e da solução sólida (U,Er) $\mathrm{O}_{2}$, em razão da porcentagem mássica de $\mathrm{Er}_{2} \mathrm{O}_{3}$. Os valores foram calculados a partir da equação 4. A barra azul foi sobreposta a barra laranja e representa as densidades das pastilhas calculadas pelo método de Arquimedes, no qual foi feito a curva média de como a densidade da pastilha diminui com a adição do $\operatorname{Er}_{2} \mathrm{O}_{3}$. A porcentagem apresentada acima da barra laranja representa a razão entre a densidade da pastilha e sua densidade teórica, podendo estabelecer o nível de porosidade presente em cada pastilha.

Nota-se que mesmo com a diminuição do parâmetro de rede, e consequentemente, do volume da célula unitária, a densidade do composto diminui, uma vez que a substituição de átomos (urânio por érbio) ocorre por um átomo mais leve $\mathrm{e}^{/ 30 /}$. 
A especificação do combustível nuclear (U,Gd)O $\mathrm{O}_{2}$ permite a variação de densidade da pastilha entre 9,98 e $10,28 \mathrm{~g} / \mathrm{cm}^{3 / 53 /}$. Caso essa especificação fosse utilizada para o (U,Er) $\mathrm{O}_{2}$, as pastilhas com 4,0\% e 9,8\% estariam no limite superior e inferior.

Apesar das misturas de pós do $\mathrm{UO}_{2}$ e $\mathrm{Er}_{2} \mathrm{O}_{3}$ serem feitas de forma mecânica, entende-se que o procedimento adotado fez com que o $\mathrm{Er}_{2} \mathrm{O}_{3}$ tenha sido solubilizado totalmente na mistura, uma vez que não foi observado picos de difração diferentes da fase cristalina do $\mathrm{UO}_{2}$ nas pastilhas produzidas nesse trabalho ${ }^{154}$. Os difratogramas das composições de $\mathrm{UO}_{2}$ puro e suas misturas com $\mathrm{Er}_{2} \mathrm{O}_{3}$ estão apresentados na figura 22.

Figura 22: Difratogramas de raios $\mathrm{x}$ das pastilhas de $\mathrm{UO}_{2}$ e $(\mathrm{U}, \mathrm{Er}) \mathrm{O}_{2}$

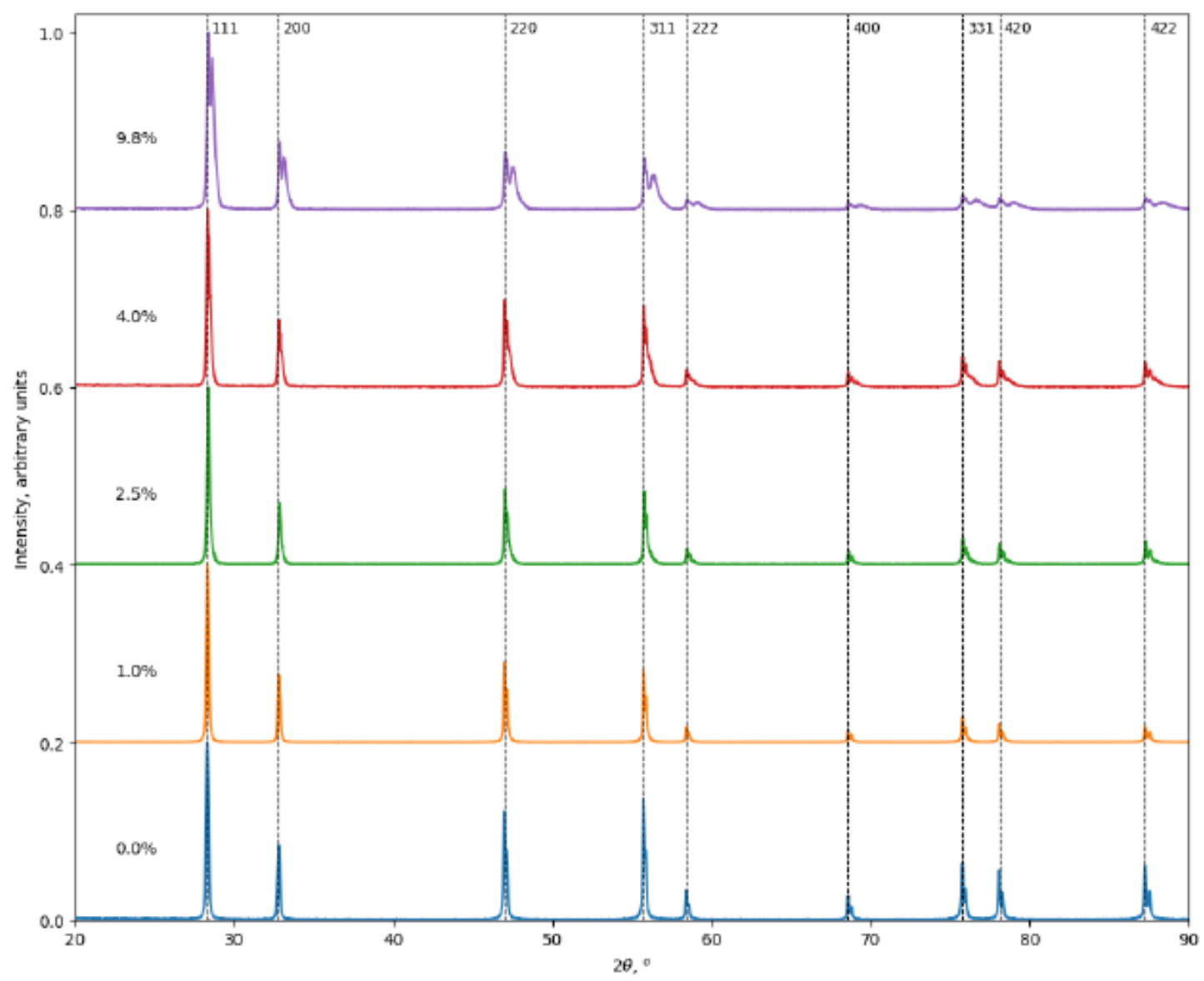

Fonte: Sansone, Riella e Urano de Carvalho, 2017 ${ }^{\text {/54/ }}$ 
Foram feitas micrografias das pastilhas sinterizadas de $\mathrm{UO}_{2}$, assim como as pastilhas dopadas com érbio, nas proporções de 1,0\% a 9,8\%, obtidas por microscópio eletrônico de varredura, utilizando tensão de $20 \mathrm{kV}$ e aumento de 500 vezes e apresentado na figura 23. Observa-se nas figuras que a sinterização formou porosidade fechada e com pouca diferença entre a quantidade de poros entre as pastilhas com érbio. Apesar da variação de densidade da pastilha sinterizada, esse resultado era esperado, uma vez que a densidade teórica da mistura UO2-Er2O3 é diminuída como visto na figura 21.

Figura 23: Micrografia eletrônica de varredura das pastilhas (a) $\mathrm{UO}_{2}$, (b) $\mathrm{UO}_{2} .1,0 \% \mathrm{Er}_{2} \mathrm{O}_{3}$, (c) $\mathrm{UO}_{2} .2,5 \% \mathrm{Er}_{2} \mathrm{O}_{3}$, (d) $\mathrm{UO}_{2} \cdot 4,0 \% \mathrm{Er}_{2} \mathrm{O}_{3}$ e (e) $\mathrm{UO}_{2} .9,8 \% \mathrm{Er}_{2} \mathrm{O}_{3}$

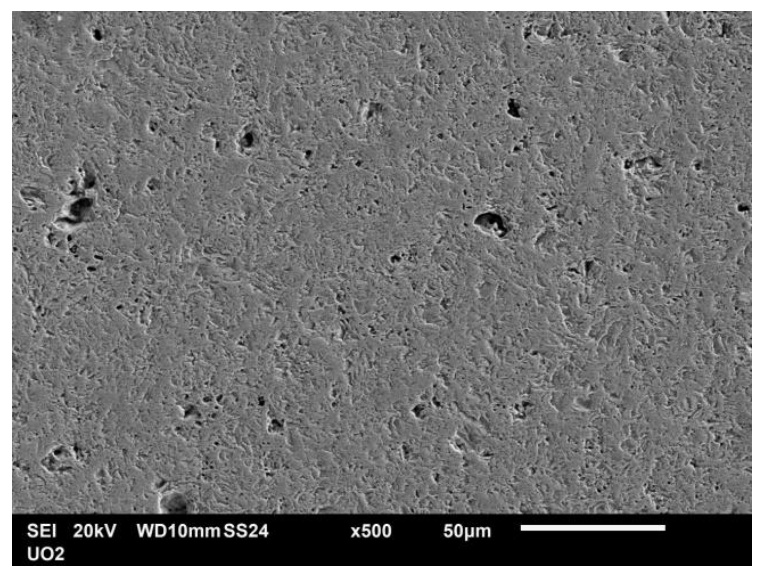

(a)

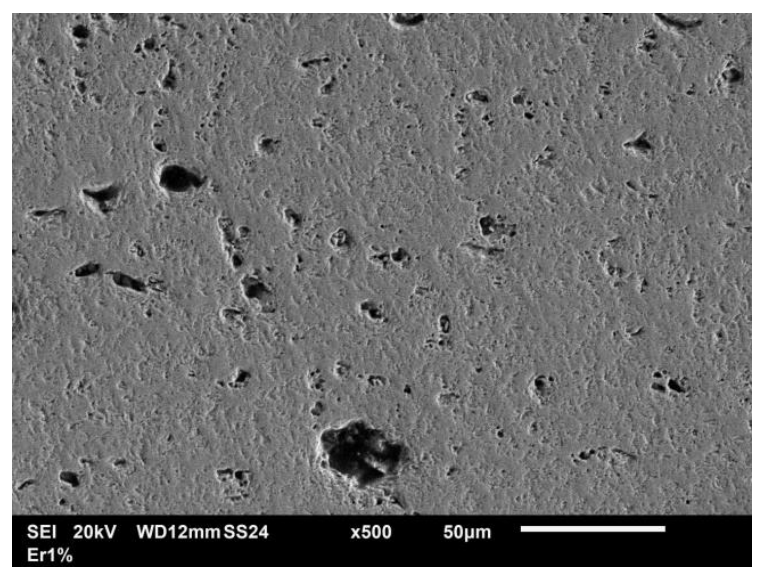

(b)

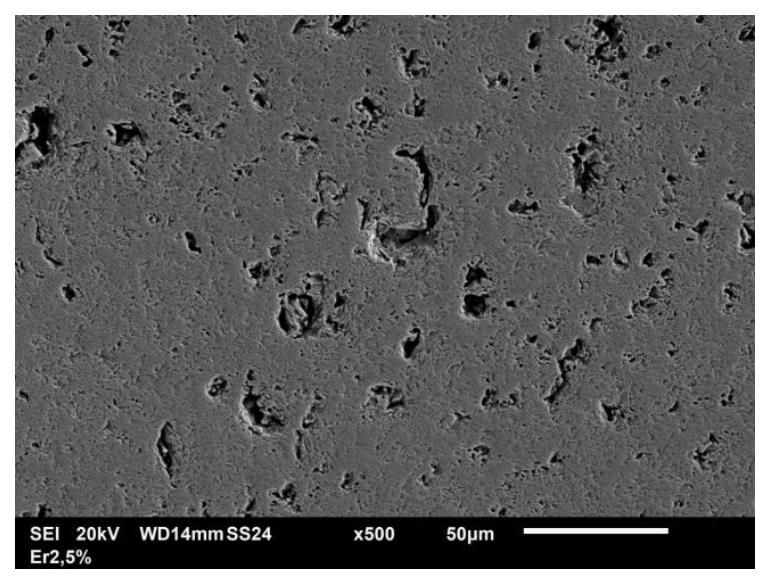

(c) 


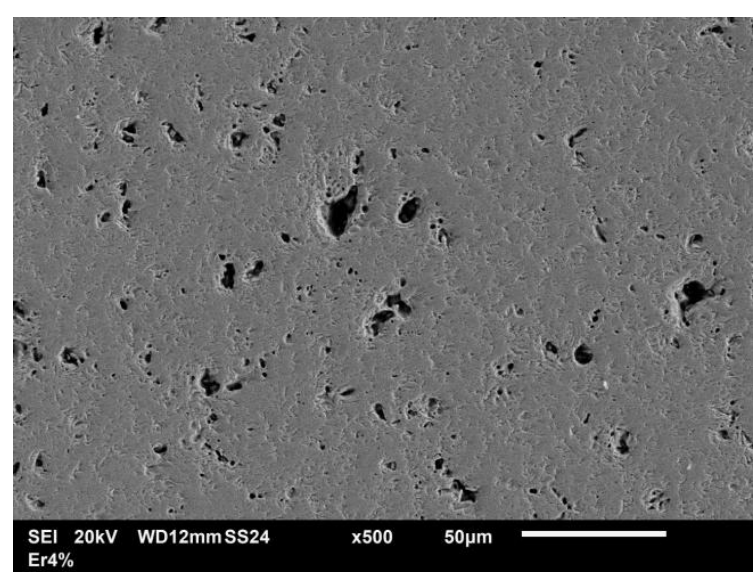

(d)

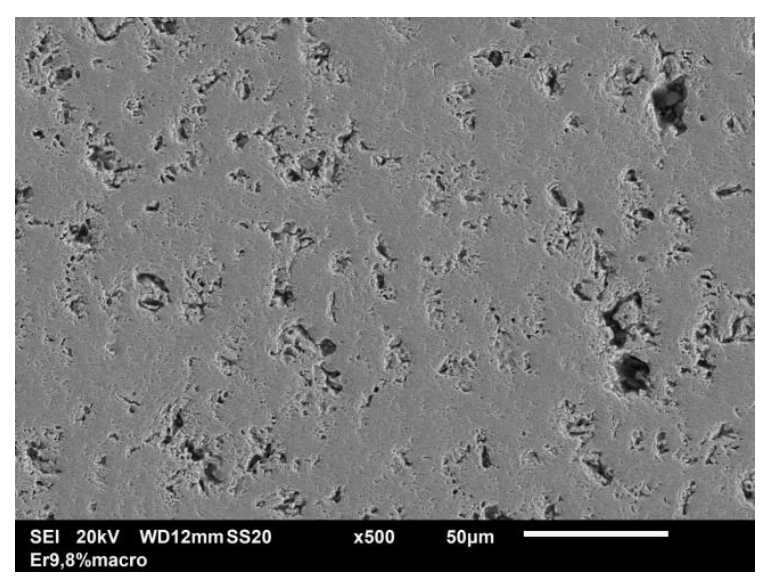

(e)

Fonte: Autor da dissertação

A porosidade presente nas micrografias da figura 23 decorre da sinterização, já que o principal mecanismo de retração da pastilha é a diminuição da porosidade. As pastilhas foram compactadas com valores próximos a 50\% da densidade teórica e após a sinterização possuem entre $95,2 \%$ e $92,1 \%$ da densidade teórica. Outro item que contribui para formação da porosidade é o lubrificante. À medida que ocorre o aquecimento do forno, o lubrificante reage com a atmosfera do forno, formando um gás que passa pela porosidade aberta, presente no inicio da sinterização. E por último, o segundo formador de porosidade corresponde as partículas de óxido de érbio, que se solubilizam na matriz de $\mathrm{UO}_{2}$, formando a solução sólida, causando o efeito Kirkendall e consequentemente a diminuição da densidade.

Os resultados obtidos na dilatometria das pastilhas (U,Er) $\mathrm{O}_{2}$ não puderam ser comparado pela inexistência de literatura nessa mesma análise. As especificações do combustível mencionado também não estão disponíveis. Os trabalhos existentes com a utilização do érbio como material absorvedor são focados na a simulação do desempenho neurônico do combustível ( $\mathrm{U}, \mathrm{Er}) \mathrm{O}_{2}$, estudos que analisam propriedades físicas, tendo como origem um material isento de porosidade, utilizando portanto roteiros de homogeneização, compactação e sinterização diferentes desse estudo, e analises de parâmetro de rede.

Acredita-se que a pouca literatura existente sobre $\mathrm{UO}_{2}-\mathrm{Er}_{2} \mathrm{O}_{3}$ está relacionada ao caráter comercial dos combustíveis nucleares e o maior interesse da comunidade 
científica pelo combustível (U,Gd)O $\mathrm{O}_{2}$. Por esse motivo, esse trabalho se ateve a comparar os resultados com os estudos existente com pastilhas $(\mathrm{U}, \mathrm{Gd}) \mathrm{O}_{2}$, no qual foi possível perceber resultados melhores relacionados a retração, como apresentados nas figuras 16 e 17.

A técnica de dilatometria se mostrou consistente para análise da sinterização das pastilhas, uma vez que foi possível evidencia o bloqueio de sinterização e determinar a temperatura que o érbio solubiliza na matriz de $\mathrm{UO}_{2}$. Com isso, as previsões já estudas com o combustível (U,Gd)O $\mathrm{O}_{2}$ pode ser relacionada com o $(\mathrm{U}, \mathrm{Er}) \mathrm{O}_{2}$ 


\section{CONCLUSÕES}

Foi realizada uma investigação sobre o comportamento da pastilha, à medida que se aumenta a concentração de érbio, na forma de óxido, visando entender sua influência, assim como a aplicabilidade desse veneno queimável de forma integrada ao combustível nuclear.

A partir dos resultados experimentais apresentados, podem-se destacar os seguintes aspectos:

Os ensaios dilatométricos indicam uma retração de 21,9\%, 20,3\%, 20,0\% e $19,0 \%$ paras pastilhas $\mathrm{UO}_{2} .1,0 \% \mathrm{Er}_{2} \mathrm{O}_{3}, \quad \mathrm{UO}_{2} .2,5 \% \mathrm{Er}_{2} \mathrm{O}_{3}, \quad \mathrm{UO}_{2} .4,0 \% \mathrm{Er}_{2} \mathrm{O}_{3} \quad$ e $\mathrm{UO}_{2} .9,8 \% \mathrm{Er}_{2} \mathrm{O}_{3}$, respectivamente. A pastilha com $\mathrm{UO}_{2}$ puro teve retração de $19,9 \%$.

O érbio age como um agente densificador para concentrações de até $4 \%$ em massa, aumentando a retração da pastilha combustível.

Os ensaios para determinação da densidade hidrostática indicam os valores de $10,42 \mathrm{~g} / \mathrm{cm}^{3}, 10,33 \mathrm{~g} / \mathrm{cm}^{3}, 10,28 \mathrm{~g} / \mathrm{cm}^{3}$ e $9,98 \mathrm{~g} / \mathrm{cm}^{3}$, paras pastilhas $\mathrm{UO}_{2} .1,0 \% \mathrm{Er}_{2} \mathrm{O}_{3}$, $\mathrm{UO}_{2} .2,5 \% \mathrm{Er}_{2} \mathrm{O}_{3}, \mathrm{UO}_{2} .4,0 \% \mathrm{Er}_{2} \mathrm{O}_{3}$ e $\mathrm{UO}_{2} .9,8 \% \mathrm{Er}_{2} \mathrm{O}_{3}$, respectivamente. A pastilha com $\mathrm{UO}_{2}$ puro teve densidade de $10,45 \mathrm{~g} / \mathrm{cm}^{3}$.

$\mathrm{O}$ bloqueio de sinterização visualizado no sistema $\mathrm{UO}_{2}-\mathrm{Gd}_{2} \mathrm{O}_{3}$ que ocorre na faixa de temperatura de $1300-1650^{\circ} \mathrm{C}$ retardando a densificação, com a mistura $\mathrm{UO}_{2}$ $\mathrm{Er}_{2} \mathrm{O}_{3}$ foi observado, porém de forma menos intensa, ocorrendo à temperatura de $1550^{\circ} \mathrm{C}$.

Os resultados demonstram a aplicabilidade desse veneno queimável de forma integrada ao combustível tradicional de $\mathrm{UO}_{2}$, podendo ser uma alternativa para o país, através da Eletronuclear, para aumentar o ciclo de queima, sem necessidade de uma grande alteração no processo de fabricação do combustível. 


\section{REFERÊNCIAS BIBLIOGRÁFICAS}

1. REIS, L. B.; SANTOS, E. C. Energia elétrica e sustentabilidade - Aspectos tecnológicos, socioambientais e legais. Editora Manole. 2015.

2. Apostila educativa - História da energia nuclear. COMISSÃO NACIONAL DE ENERGIA NUCLEAR - CNEN. Disponível em: www.cnen.gov.br. Acessado em julho/2017.

3. INTERNATIONAL ATOMIC ENERGY AGENCY - IAEA. Indicators for Nuclear Power Development. No NG-T-4. 5. Viena. 2015.

4. Dados operacionais. ELETRONUCLEAR. Disponível em: <http://www.eletronuclear.gov.br>. Acesso em agosto/2017.

5. SANTOS, L. R., Estudo do processamento do combustível nuclear $\mathrm{UO}_{2}-7 \% \mathrm{Gd}_{2} \mathrm{O}_{3}$ via mistura mecânica com reutilização de rejeitos do processo de fabricação e aditivo de densificação. Tese (Doutorado em Tecnologia Nuclear) - Instituto de Pesquisas Energéticas Nucleares - IPEN-CNEN/SP. 2009.

6. DURAZZO, M., Estudo de mecanismo de bloqueio da sinterização do sistema $\mathrm{UO}_{2-}$ $\mathrm{Gd}_{2} \mathrm{O}_{3}$. Tese (Doutorado em Tecnologia Nuclear) - Instituto de Pesquisas Energéticas Nucleares - IPEN-CNEN/SP. 2001.

7. DUDERSTADT, J. J.; HAMILTON, J. L. Nuclear Reactor Analysis. New York: John Wiley \& Sons, Inc., 1976.

8. PORTA, J., ASSON, M. Alternative poison? Stabilization additive? What future? Progress in Nuclear Energy. Elsevier. Vol. 38, p. 347-350. 2001.

9. SERAFIM, A. C., Estudo de Densificação do Combustível Urânio - 7\% Gadolínio $\left(\mathrm{Gd}_{2} \mathrm{O}_{3}\right)$ nanoestruturado. Dissertação (Mestrado em Tecnologia Nuclear) - Instituto de Pesquisas Energéticas Nucleares - IPEN-CNEN/SP. Tese de mestrado IPEN/ USP. 2016.

10. OLDENBERG, O., HOLLADAY, W. G. Introdução à física atômica e nuclear. Editora: Edgard Blucher Ltda, 1971.

11. MARTIN, F. S., MILES G. L., Chemical Processing of Nuclear Fuels. Editora: Butterworths Scientific Publications. 1958.

12. TERREMOTO, L. A. A. Fundamentos da Tecnologia Nuclear - Reatores. IPEN. 2004.

13. ASSOU, M., PORTA, J. Prospects for poisoning reactor cores of the future. Nucl. Eng. Design.V. 168, p. 261-270. 1997. 
14. INTERNATIONAL ATOMIC ENERGY AGENCY. Characteristics and use of uraniagadolinia fuels. IAEA-TECDOC-844. Vienna, Austria: IAEA, 1995.

15. FRANCESCHINI, F., PETROVIC, B., Use of isotopically modified erbium to improve fuel cycle economics in IRIS. $5^{\text {th }}$ International conference on nuclear options in countries with small and medium electricity grids. Croatia. 2004.

16. BARCHEVTSEV, V., ARTISYUK, V., NINOKATA, H., Concept of erbium doped uranium oxide fuel cycle in light water reactor. Tokyo Institute of Technology. Journal of nuclear science and technology. Vol. 39, nº. 5, p. 506-513. 2002.

17. GAVIN, P. H.; JONSSON, A.; SWOOPE, S.; CHANG, R. Y.; THOMSEN, O. J. Lead test fuel assembly physics for erbium fuel at San Onofre nuclear generating station. Trans. Am. Nucl. Soc., v. 68, part A, p. 443-445, 1993.

18. JONSSON, A. Initial physiscs evaluation of erbium as burnable absorver in a PWR. Trans. Am. Nucl. Soc., v. 61, p. 340-341, 1990.

19. JONSSON, A. Comparison of the relative importance of constraints in the design of burnable absorbers for 17 X 17 PWR fuel in a 18-month cycle. Trans. Am. Nucl. Soc., v. 75, p. 355-356, 1996.

20. DEHAUDT, Ph., LEMAINGNAN, C., CAILlOT, L., MOCELLIN, A., EMINET, G. New $\mathrm{UO}_{2}$ fuel studies. Nuclear Reactor Directorate. International Atomic Energy Agency (IAEA). IAEA-TECDOC-1036. France. 1998.

21. RENIER, J. P. A., GROSSBECK, M. L., Development of improved burnable poisons for commercial nuclear power reactor. OAK Ridge National Laboratory. U. S. Department of Energy. 2001.

22. MARA0, A., KALIATKA, T., USPURAS, E. Analysis of processes in RBMK-1500 fuel assemblies during normal operation cycle. Lithuanian Energy Institute.

Energetika. 2010.

23. DURAZZO, M., SALIBA-SILVA, A. M., URANO DE CARVALHO, E. F., RIELLA, H. G., Sintering behavior of $\mathrm{UO}_{2}-\mathrm{Gd}_{2} \mathrm{O}_{3}$ fuel: pore formation mechanism. Journal of Nuclear Materials. 433. 334-340. 2013.

24. LIMA, M. M. F., FERRAZ, W. B., SANTOS, M. M. PINTO, L. C. M., SANTOS, A. Study of $\mathrm{UO}_{2}-10 \mathrm{wt} \% \mathrm{Gd}_{2} \mathrm{O}_{3}$ fuel pellets obtained by seeding method using AUC coprecipitation and mechanical mixing process. $18^{\circ}$ CBECIMat - Congresso Brasileiro de Engenharia e Ciência dos Materiais. Brasil, PE. 2008.

25. PALANKI, B., Fabrication of $\mathrm{UO}_{2}-\mathrm{Gd}_{2} \mathrm{O}_{3}$ fuel pellets. Journal of Materials Science and Chemical Engineering. 4, 8-21. 2016. 
26. COSTA, D. R., EZEQUIEL, F. J., GONZAGA, R., BERNARDELLI, S. H. Individual influence of $\mathrm{Al}_{2} \mathrm{O}_{3}$ and $\mathrm{Nb}_{2} \mathrm{O}_{5}$ on grain growth of $\mathrm{UO}_{2}$ sintered pellets manufactured an INB. International Nuclear Atlantic Conference. Associação Brasileira de Energia Nuclear - CNEN. Brasil. 2013.

27. PETROV, I. V., BASOV, V. V., Behavior of uranium-erbium oxide fuel pellets during cyclic heat treatment. Atomic Energy. Vol. 107, nº 4. 2009.

28. FERRARI, K. R. Variação da Razão Estequiométrica O/OU Durante a Estocagem do Combustível Nuclear $\mathrm{UO}_{2}$. Dissertação (Mestrado em Tecnologia Nuclear) Instituto de Pesquisas Energéticas Nucleares - IPEN-CNEN/SP. 1995.

29. Estrutura cristalina $\mathrm{UO}_{2}$. JCPDS 76-1118

30. FEDOTOV, A. V., MIKHEEV, E. N., LYSIKOV, A. V., NOVIKOV, V. V., Theoretical and experimental density of $(\mathrm{U}, \mathrm{Gd}) \mathrm{O}_{2}$ and $(\mathrm{U}, \mathrm{Er}) \mathrm{O}_{2}$.Atomic Energy. Vol $113, n^{\circ} 6.2013$.

31. CALLISTER, W. D., Ciência e Engenharia de Materiais: Uma Introdução. John Wiley \& Sons, Inc., 2002.

32. Estrutura cristalina $\mathrm{Er}_{2} \mathrm{O}_{3}$. JCPDS 77-0777

33. KANG, S. J. L. Sintering - Densification, Grain Growth, and Microstruture. London: Elsevier Butterworth Heinemann. 2005.

34. GERMAN, R. M., Powder Metallurgy Science. MPIF. Princeton, USA. 1994.

35. SILVA, S. L., Cinética de sinterização do combustível nuclear $\mathrm{UO}_{2} .7 \% \mathrm{Gd}_{2} \mathrm{O}_{3}$ : Cálculo da curva mestre de sinterização. Dissertação (Mestrado) - Universidade Estadual Julio de Mesquita Filho - UNESP - Sorocaba. 2010.

36. HO, S. M., RADFORD, K. C., Structural chemical of solid solutions in the $\mathrm{UO}_{2}-\mathrm{Gd}_{2} \mathrm{O}_{3}$ system. Nuclear Tecnology 73. p. 350-360. Amercian Nuclear Society. 1986.

37. KIM, S. H., KIM, H. S., LEE, Y. W., SOHN, D. S., SUHR, D. S., Thermal expansion of near stoichiometric (U,Er) $\mathrm{O}_{2}$ solid solution. Materials Letters. 60, 1480-1483. 2006.

38. YAMANKA, S. KUROSAKI, K., KATAYAMA, M., ADACHI, J., UNO, M., KUROISHI, T., YAMASAKI, M., Thermal and mechanical properties of (U,Er) $\mathrm{O}_{2}$. Journal of Nuclear Materials. 386, p. 115-118. 2009.

39. FUKUSHIMA, S., OHMICHI, T., MAEDA, A., WATANABE, H., Ther effect of gadolinium content on the thermal conductivity of near-stoichiometric $(\mathrm{U}, \mathrm{Gd}) \mathrm{O}_{2}$ solid solutions. Journal of Nuclear Materials. 105, p. 201-210. 1982. 
40. KIM, S. H., KIM, Y. G., KIM, H. S., NA, S. H., LEE, Y. W., SUHR, D. S., Thermal conductivity of near stoichiometric $(\mathrm{U}, \mathrm{Er}) \mathrm{O}_{2}$ solid solution. Journal of Nuclear Materials. 342, p. 119-124. 2005.

41. SPEYER, R. F., Thermal Analysis of Materials. Taylor \& Francis Group. LCC. New York. 1993.

42. RESTIVO, T. A. G., SILVA, S. L., Specific surface area determination by TG/ DSC. Thermochimica Acta. 328, p. 47-53. 1999.

43. CULLITY, B. D., Elements of X-Ray Diffraction. Addison-Wesley Publishing Company INC. USA. 1993.

44. IERVOLINO, F., BULLA, L., A Metalurgia do Pó - Alternativa Econômica com Menor Impacto Ambiental. Cap 7: Compactação. Metallum Eventos Técnicos. Brasil, SP. 2009.

45. Aluminum distearate propetiers. Diponível em:

https://www.americaelements.com/aluminum-distearate-300-92-5. Acessado em julho/ 2017

46. KANG, K. W., YANG, J. H., KIM, J. H., RHEE, Y. W., KIM., D. J., KIM, K. S., SONG, K. W., The solidus and liquidus temperatures of $\mathrm{UO}_{2}-\mathrm{Gd}_{2} \mathrm{O}_{3}$ and $\mathrm{UO}_{2}-\mathrm{Er}_{2} \mathrm{O}_{3}$ fuels. Termochinamica Acta. 455, p. 134-137. 2007.

47. ASTM C373-88, Annual Book of ASTM Standards. 115. 1992.

48. GONÇALVES, V. S., PAPINI, C. J., LEAL NETO, R. M., Comparação de métodos de determinação da densidade aparente de pastilhas de $\mathrm{NbAl}_{3} . \mathbf{1 5}^{\circ}$ CBECIMat -

Congresso Brasileiro de Engenharia e Ciência dos Materiais.Natal, RN. 2002.

49. DRX UO $\mathrm{UP}_{2}$ PDF 41-1422.

50. DRX $\mathrm{Er}_{2} \mathrm{O}_{3}$. PDF 08-0050.

51. DURAZZO, M., OLIVEIRA, F. B. V., URANO DE CARVALHO, E. F., RIELLA, H. G., Phase studies in the $\mathrm{UO}_{2}-\mathrm{Gd}_{2} \mathrm{O}_{3}$ system. Journal of Nuclear Materials. 430. 183188. 2010.

52. MOURA, S. C., Determinação da razão estequiométrica em amostras de dióxido de urânio. Dissertação (Mestrado em Tecnologia Nuclear) - Instituto de Pesquisas Energéticas Nucleares - IPEN-CNEN/SP Tese de mestrado IPEN/ USP. 1999.

53. SANTOS, L. R., DURAZZO, M., URANO DE CARVALHO, E.F., RIELLA, H. G., Effect of $\mathrm{Al}(\mathrm{OH}) 3$ on the sintering of $\mathrm{UO}_{2}-\mathrm{Gd}_{2} \mathrm{O}_{3}$ fuel pallets with addition of $\mathrm{U}_{3} \mathrm{O}_{8}$ from recycle. Journal of Nuclear Materials. 493. 30-39. 2017. 
54. SANSONE, A. E. S., RIELLA, H. G., URANO DE CARVALHO, E., F., Characterization of crystalline phase of $(\mathrm{U}, \mathrm{Er}) \mathrm{O}_{2}$ pellets by x-ray difraction. International Nuclear Atlantic Conference. Associação Brasileira de Energia Nuclear - ABEN. Brasil. 2017. 


\section{ANEXOS}

\section{Anexo I - Cartão PDF do $\mathrm{UO}_{2}$}

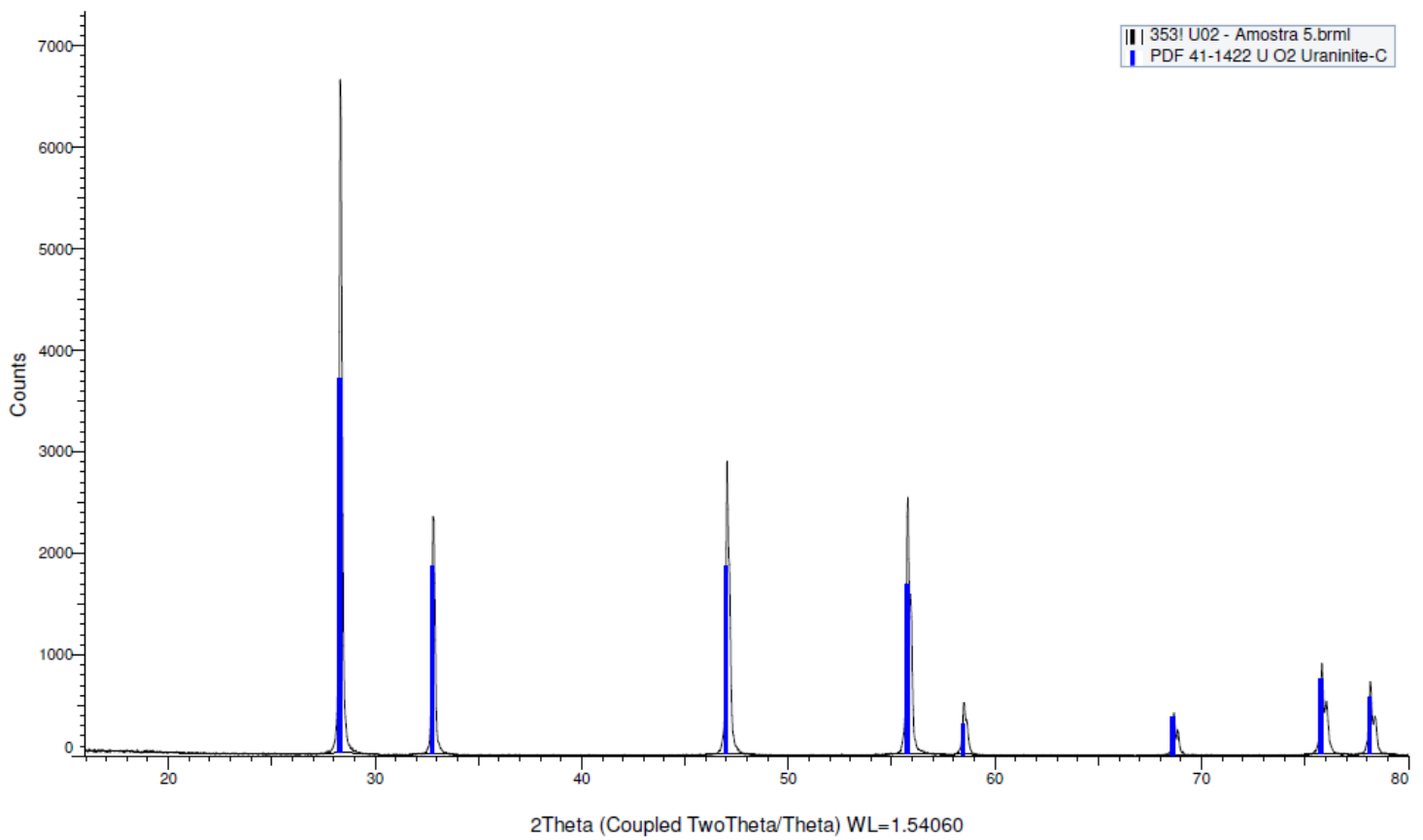




\section{Pattern: PDF 41-1422 Radiation: 1.54060 Quality: Star (*)}

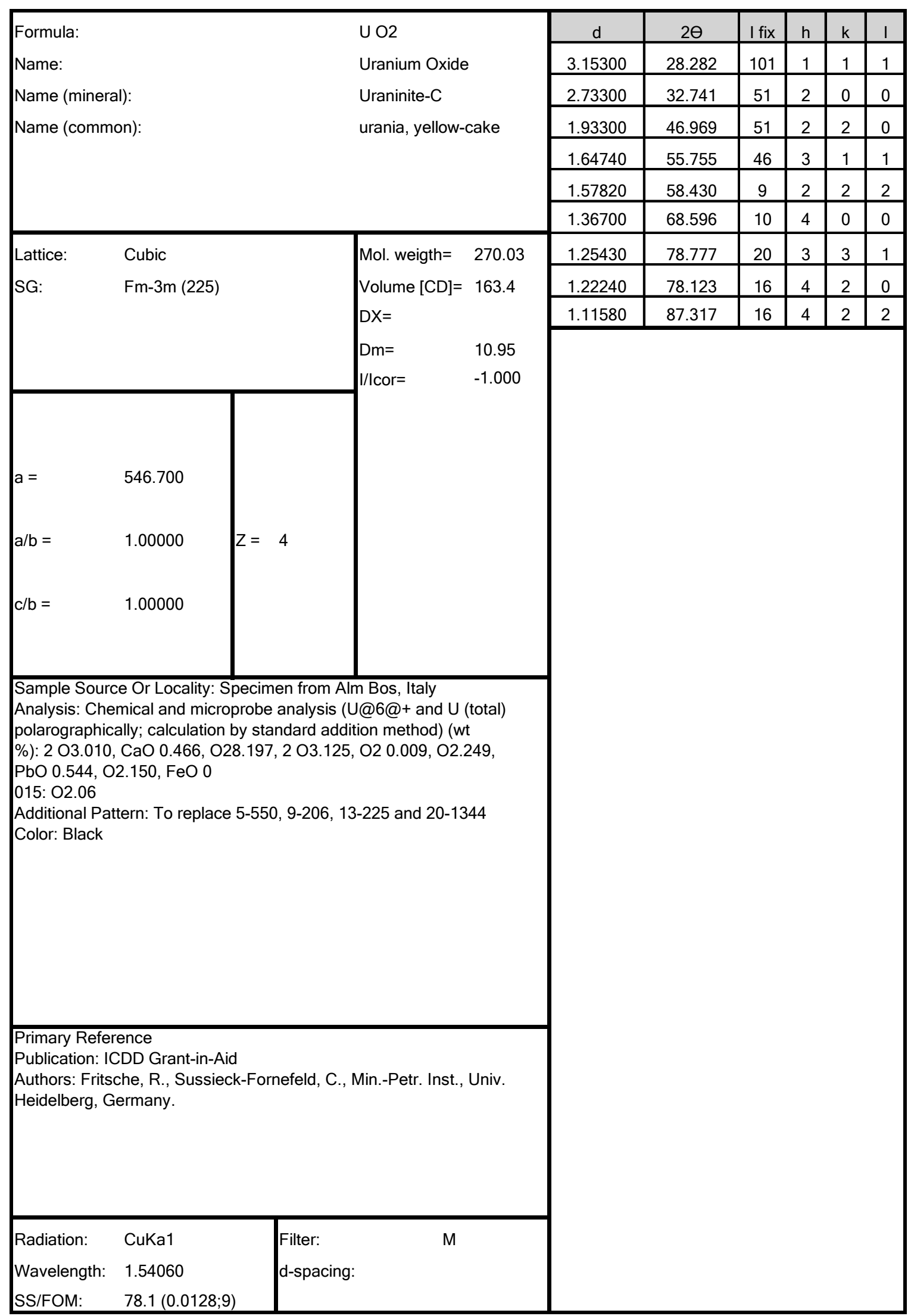


Anexo I - Cartão PDF do $\mathrm{Er}_{2} \mathrm{O}_{3}$

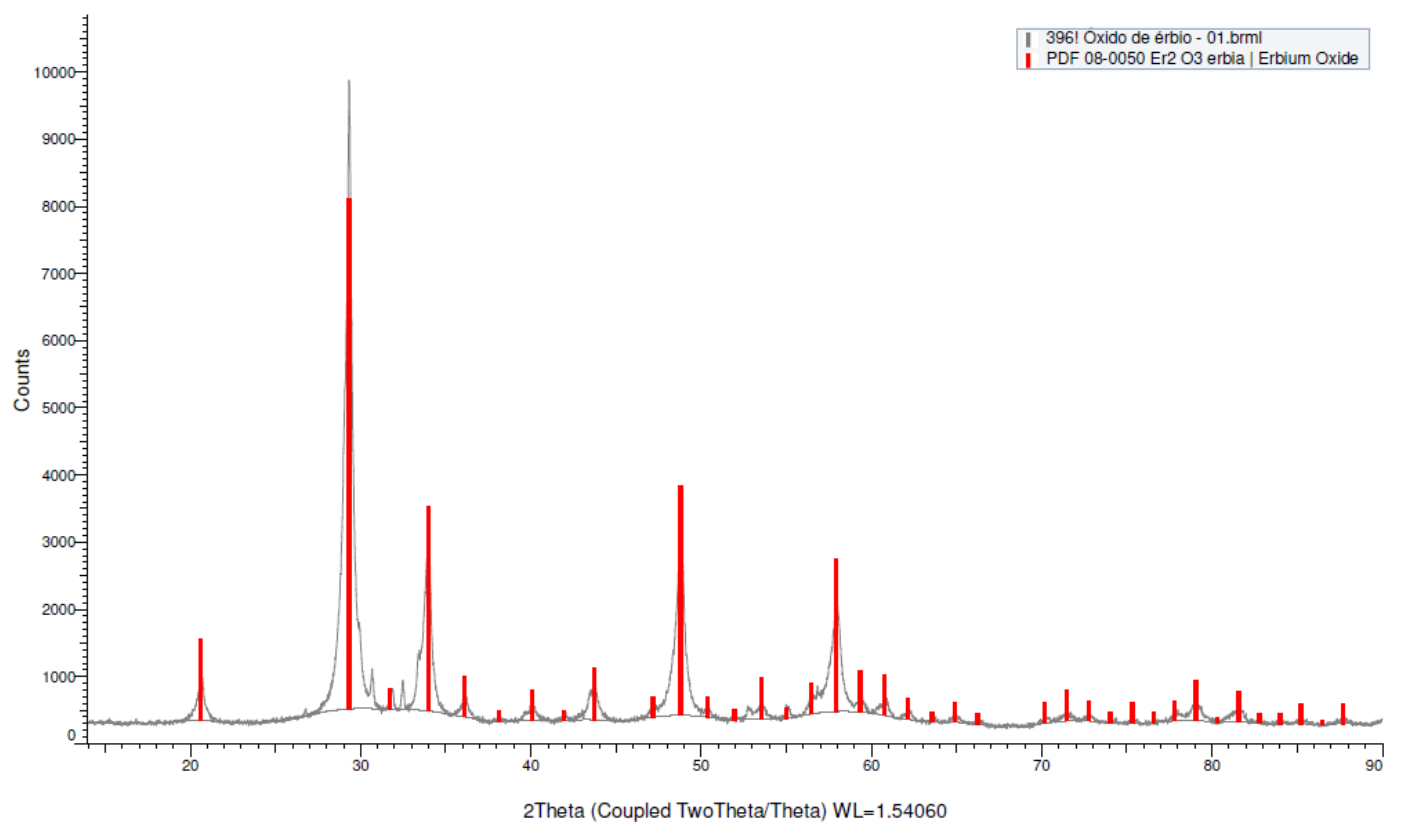




\section{Pattern: PDF 08-0050 Radiation: 1.54060 Quality: Star (*)}

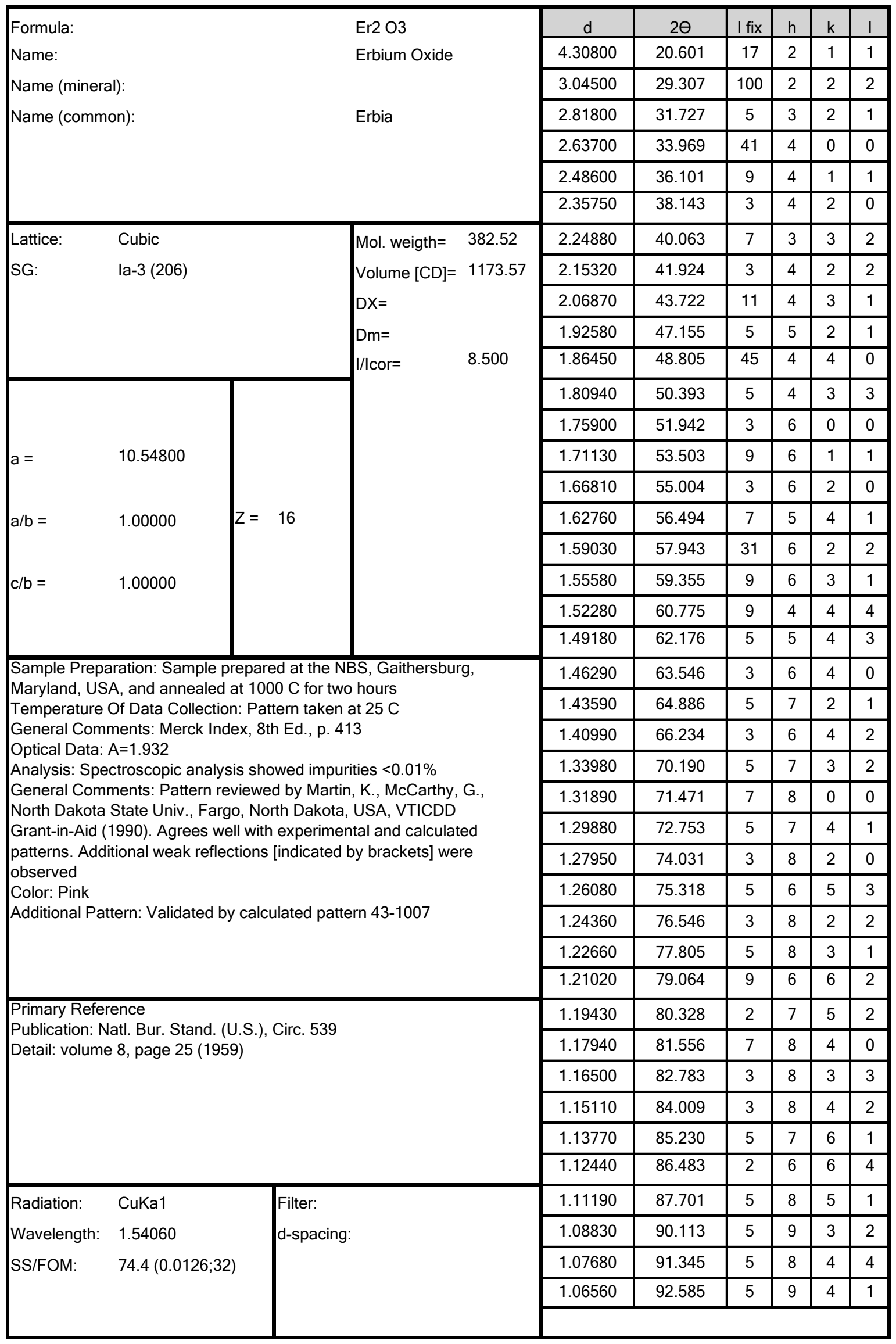




\section{INSTITUTO DE PESQUISAS ENERGÉTICAS E NUCLEARES}

Diretoria de Pesquisa, Desenvolvimento e Ensino

Av. Prof. Lineu Prestes, 2242 - Cidade Universitária CEP: 05508-000

Fone/Fax(0XX11) 3133-8908

SÃO PAULO - São Paulo - Brasil

http://www.ipen.br

O IPEN é uma Autaquia vinculada à Secretaria de Desenvolvimento, associada à Universidade de São Paulo e gerida técnica e administrativamente pela Comissão Nacional de Energia Nuclear, órgão do Ministério da Ciência, Tecnologia e Inovação. 